University of San Diego

Digital USD

2010-05-01

\title{
Using Internet Videoconferencing to Connect Fashion Students With Apparel Industry Professionals
}

Vera Bruce Ashley EdD

University of San Diego

Follow this and additional works at: https://digital.sandiego.edu/dissertations

Part of the Leadership Studies Commons

\section{Digital USD Citation}

Ashley, Vera Bruce EdD, "Using Internet Videoconferencing to Connect Fashion Students With Apparel Industry Professionals" (2010). Dissertations. 897.

https://digital.sandiego.edu/dissertations/897

This Dissertation: Open Access is brought to you for free and open access by the Theses and Dissertations at Digital USD. It has been accepted for inclusion in Dissertations by an authorized administrator of Digital USD. For more information, please contact digital@sandiego.edu. 


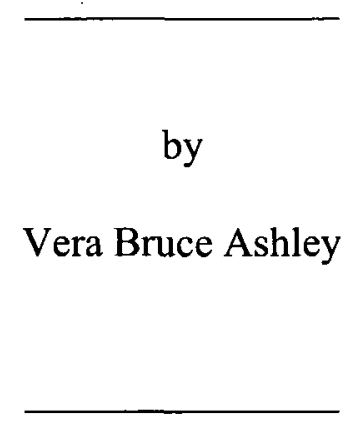

A Dissertation Submitted to the Faculty of

San Diego State University and the University of San Diego

in Partial Fulfillment

of the Requirements for the Degree

Doctor of Education

Dissertation Committee:

Douglas Fisher, Ph.D., San Diego State University

Bernard Dodge, Ph.D., San Diego State University

Susan M. Zgliczynski, Ph.D., University of San Diego

May 2010 
Copyright (C) 2010

by

Vera Bruce Ashley 


\section{DEDICATION}

I would first like to acknowledge and give thanks to God for His unsearchable riches in Christ Jesus and for His orchestration in allowing me to obtain this place in this life and security in the next.

I would like to dedicate this doctoral dissertation to my mother who believed that I could do anything I wanted to do. I know that she would have been so proud of me. I see it in her smile.

I also dedicate this dissertation to my husband, Craig, who I met while an undergraduate and married 34 years later. He shared my graduation with me then, as an undergraduate, and is sharing this graduation with me now, as a Doctor of Education. Our relationship has come full circle in so many ways. He has been loving, supportive, and encouraging in my pursuit of this degree. In more ways, than I can name, I could not have chosen a better man with whom to share my life and accomplishments. 


\title{
ABSTRACT OF THE DISSERTATION
}

\author{
Using Internet Videoconferencing to Connect Fashion \\ Students with Apparel Industry Professionals \\ by \\ Vera Bruce Ashley \\ Doctor of Education
}

San Diego State University and the University of San Diego, 2010

The purpose of this study was to explore the efficacy, benefits and student perceptions of using Internet videoconferencing and a web camera to connect college and university fashion students with apparel industry professionals. A total of 70 college and university fashion students, three instructors, and three apparel industry professionals participated in this introductory study. Data was collected through pre and post surveys from all three groups. Industry professionals were invited as guest speakers into the classroom via Internet videoconferencing using Skype and a web camera. The findings in the study indicated that students, instructors, and apparel industry professionals overwhelmingly benefited from this type of interaction. Although technical difficulties occurred, the effectiveness, cost, and overall benefits to the instructor, students, and industry professionals indicate a need to have this type of interaction regularly in the classroom. 


\section{TABLE OF CONTENTS}

PAGE

ABSTRACT $\ldots \ldots \ldots \ldots \ldots \ldots \ldots \ldots \ldots \ldots \ldots \ldots \ldots \ldots \ldots$

LIST OF TABLES. .......................

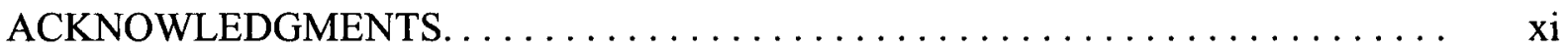

CHAPTER

1 INTRODUCTION. ........................... 1

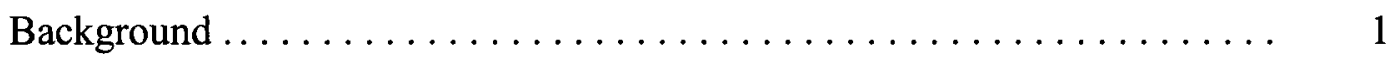

Problem Statement $\ldots \ldots \ldots \ldots \ldots \ldots \ldots \ldots \ldots \ldots \ldots$

Purpose of the Study $\ldots \ldots \ldots \ldots \ldots \ldots \ldots \ldots \ldots \ldots \ldots$

Significance of the Study $\ldots \ldots \ldots \ldots \ldots \ldots \ldots \ldots \ldots \ldots \ldots$

Definition of Terms $\ldots \ldots \ldots \ldots \ldots \ldots \ldots \ldots \ldots \ldots \ldots$

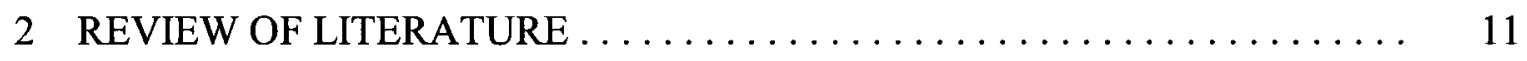

School/Industry Partnerships . . . . . . . . . . . . . . . . 11

Benefits ............................... 11

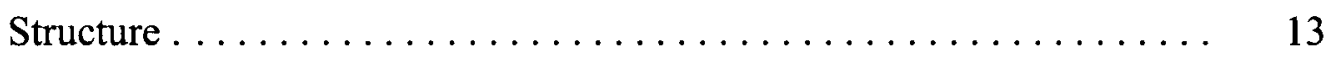

Strategies ............................ 15

Guest Speakers .......................... 18

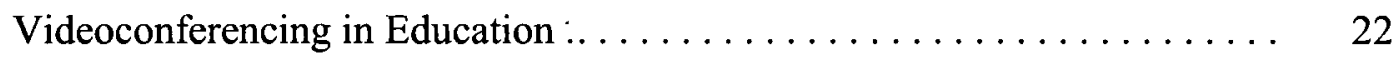

Using Skype for Videoconferencing $\ldots \ldots \ldots \ldots \ldots \ldots \ldots \ldots \ldots$

Benefits ............................ 29 


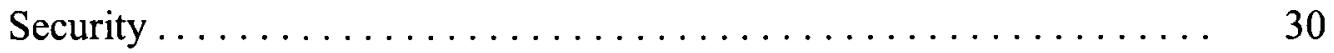

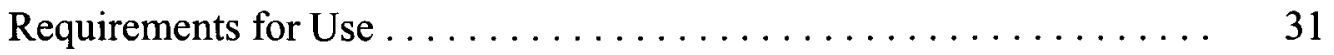

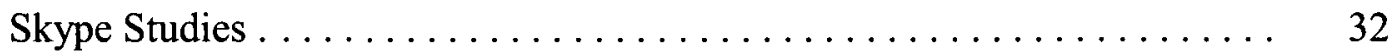

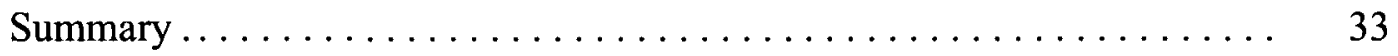

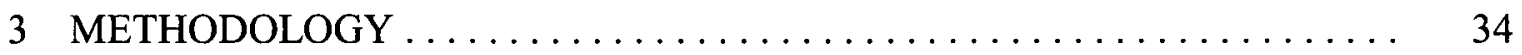

Research Design ............................. $\quad 35$

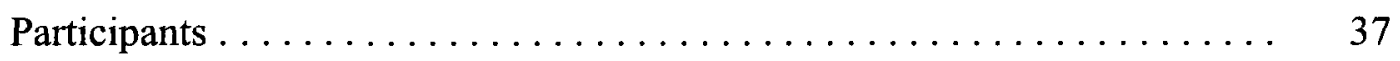

Instruments . . . . . . . . . . . . . . . . . . . . . . . .

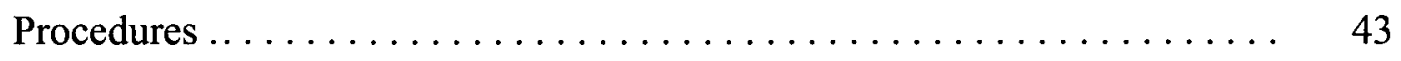

Data Analysis . . . . . . . . . . . . . . . . . . . . . 45

4 RESULTS AND FINDINGS $\ldots \ldots \ldots \ldots \ldots \ldots \ldots \ldots \ldots \ldots \ldots \ldots \ldots \ldots \ldots \ldots$

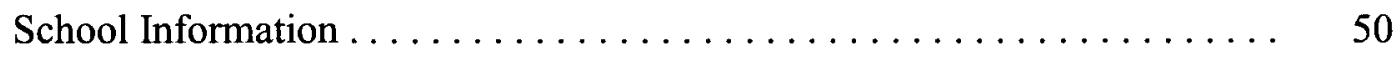

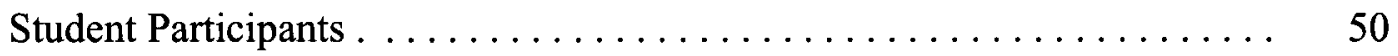

Instructor Participants $\ldots \ldots \ldots \ldots \ldots \ldots \ldots \ldots \ldots \ldots \ldots \ldots \ldots \ldots \ldots \ldots \ldots, \quad 51$

Industry Professional Participants $\ldots \ldots \ldots \ldots \ldots \ldots \ldots \ldots \ldots \ldots \ldots$

Research Questions Results . . . . . . . . . . . . . . . . 55

Instructor Expectations $\ldots \ldots \ldots \ldots \ldots \ldots \ldots \ldots \ldots \ldots \ldots \ldots \ldots \ldots$

Industry Professional Expectations $\ldots \ldots \ldots \ldots \ldots \ldots \ldots \ldots \ldots, \quad 58$

Qualitative Findings $\ldots \ldots \ldots \ldots \ldots \ldots \ldots \ldots \ldots \ldots \ldots \ldots \ldots \ldots \ldots \ldots, 71$

5 SUMMARY, DISCUSSION, AND RECOMMENDATIONS . . . . . . . . . . 89

Summary of the Study ........................... 89

Study Findings $\ldots \ldots \ldots \ldots \ldots \ldots \ldots \ldots \ldots \ldots \ldots \ldots \ldots \ldots \ldots \ldots \ldots \ldots \ldots \ldots$

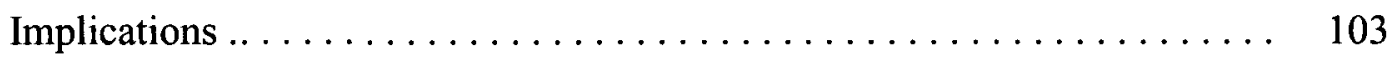




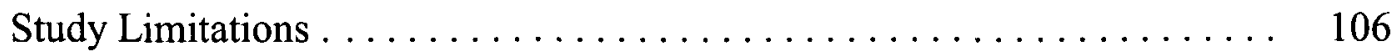

Future Research ............................. 106

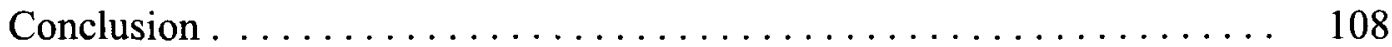

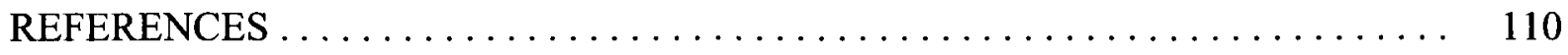

APPENDICES

A INSTRUCTOR INVITATION TO PARTICIPATE IN RESEARCH

STUDY .................................... 115

B INDUSTRY PROFESSIONAL INVITATION TO PARTICIPATE

IN RESEARCH STUDY . . . . . . . . . . . . . . . . . . . . . . . . 121

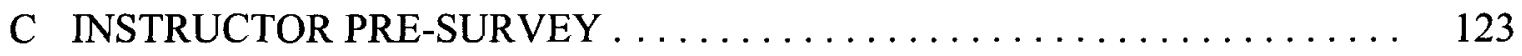

D INSTRUCTOR POST-SURVEY . . . . . . . . . . . . . . . . . 129

E STUDENT PRE-SURVEY ............................ 136

F $\quad$ STUDENT POST-SESSION SURVEY $\ldots \ldots \ldots \ldots \ldots \ldots \ldots \ldots \ldots \ldots \ldots$

G INDUSTRY PROFESSIONAL PRE-SURVEY ................. 145

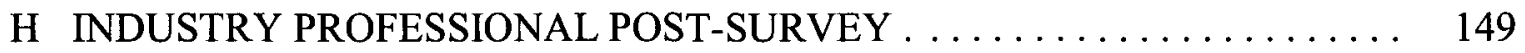

I INSTRUCTOR CONSENT FORM $\ldots \ldots \ldots \ldots \ldots \ldots \ldots \ldots \ldots \ldots \ldots \ldots \ldots \ldots$

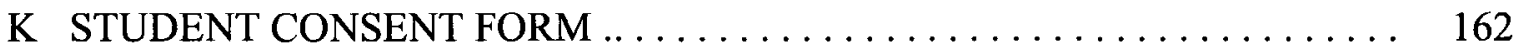




\section{LIST OF TABLES}

PAGE

Table 1. School Information $\ldots \ldots \ldots \ldots \ldots \ldots \ldots \ldots \ldots \ldots \ldots \ldots \ldots$

Table 2. Student Demographics $\ldots \ldots \ldots \ldots \ldots \ldots \ldots \ldots \ldots \ldots \ldots \ldots \ldots \ldots$

Table 3. Frequencies for Student Technology Experiences . . . . . . . . . . . 53

Table 4. Instructor Demographics $\ldots \ldots \ldots \ldots \ldots \ldots \ldots \ldots \ldots \ldots \ldots \ldots$

Table 5. Instructor Experiences with Guest Speaker . . . . . . . . . . . . 53

Table 6. Instructor Internet Experiences $\ldots \ldots \ldots \ldots \ldots \ldots \ldots \ldots \ldots \ldots \ldots \ldots$

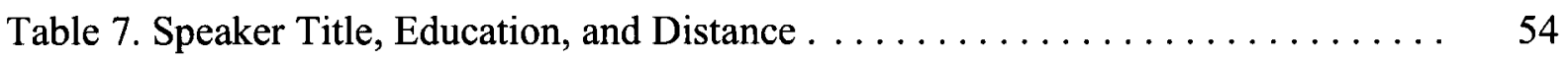

Table 8 . Guest Speaker and Skype Experience $\ldots \ldots \ldots \ldots \ldots \ldots \ldots \ldots$

Table 9. Students' Pre-Expectations Ratings $\ldots \ldots \ldots \ldots \ldots \ldots \ldots \ldots \ldots \ldots$

Table 10. Instructor A Pre-Survey Expectations $\ldots \ldots \ldots \ldots \ldots \ldots \ldots \ldots \ldots$

Table 11. Instructor B Pre-Survey Expectations $\ldots \ldots \ldots \ldots \ldots \ldots \ldots \ldots \ldots \ldots$

Table 12. Instructor $\mathrm{C}$ Pre-Survey Expectations $\ldots \ldots \ldots \ldots \ldots \ldots \ldots \ldots \ldots$

Table 13. Instructor A, B, and C Pre-Survey Expectations ... . . . . . . . . 58

Table 14. Collective Industry Professional Expectations $\ldots \ldots \ldots \ldots \ldots \ldots \ldots$

Table 15. Student Post-Expectations Ratings $\ldots \ldots \ldots \ldots \ldots \ldots \ldots \ldots \ldots \ldots \ldots \ldots$

Table 16. Paired $t$ Tests Comparing Student Pre- and Post-Expectations for All Groups ................................. 61

Table 17. ANOVAs Comparing the Difference in Pre- and Post-Expectations ... . . . 62

Table 18. Student Personality Ratings of Industry Professional ... . . . . . . . 63 
Table 19. Student Content and Effectiveness Ratings for Industry Professional ..................................... 65

Table 20. Student Technology Ratings for Industry Professional ............. 69

Table 21. Overall Student Perception Ratings for Industry Professional ......... 70

Table 22. ANOVAs Comparing Student Overall Scores for Industry Professional ....................................... 71

Table 23. Themes from Students' Assessment of the Best Part of the Videoconferencing Session $\ldots \ldots \ldots \ldots \ldots \ldots \ldots \ldots \ldots \ldots \ldots \ldots \ldots \ldots \ldots \ldots \ldots, 72$

Table 24. Themes from Students' Assessment of the Part They Liked Least of the Videoconferencing Session..$\ldots \ldots \ldots \ldots \ldots \ldots \ldots \ldots \ldots \ldots \ldots \ldots \ldots$

Table 25. Themes from Student Responses of the Most Important Thing They Learned in the Videoconferencing Session ................. 75

Table 26. Students' Choice of Single Word Describing the Session ........... 76

Table 27. Pre-Session Collective Instructor Expectations . . . . . . . . . . . . 77

Table 28. Post-Session Collective Instructor Expectations . . . . . . . . . . . 77

Table 29. Post-Session Instructors' Assessment of Met Learning Objectives ....... 78

Table 30. Instructor Post-Session Responses to Technology . . . . . . . . . . . 79

Table 31. Instructors' Ratings on Student Benefits of the Session ............. 80

Table 32. Instructors' Rating for Feasibility of the Internet Videoconferencing

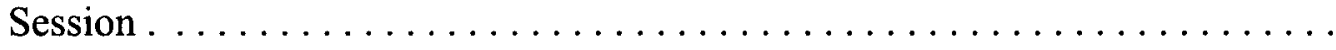

Table 33. Post-Survey Industry Professional A Assessment of Technology ....... 83

Table 34. Post-Survey Industry Professional B Assessment of Technology . . . . . . 83

Table 35. Post-Survey Industry Professional C Assessment of Technology . . . . . . . 84

Table 36. Post-Survey Collective Industry Professional Assessment of

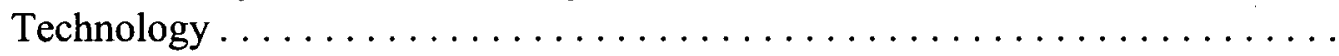




\section{ACKNOWLEDGMENTS}

First, I wish to thank my advisor, Dr. Douglas Fisher, for all his guidance, encouragement, and support throughout this dissertation process. His immediate responses to my questions and his encouraging feedback is acknowledged and genuinely appreciated. Also, I would like to thank my committee members, Dr. Susan Zgliczynski and Dr. Bernie Dodge, who have given me very helpful insights, comments, and suggestions.

I want to thank those instructors and industry professionals who believed in my project enough to become a participant and to the students whose responses formed the foundation of my dissertation, I am truly grateful.

I would also like to thank and acknowledge Logitech, Inc. for donating web cams to me early in the dissertation process.

Finally, I would like to thank my peer graduate students (affectionately known as the “car pool group"): Susan Toma-Berge, Craig Talbot, Dr. Sabine Lawless-Reljic, and Katherine Davis who, on those long drives to and from San Diego, made the commute memorable, pleasant, and filled with wonderful conversations, laughter, and encouragement. 


\section{CHAPTER 1}

\section{INTRODUCTION}

In the $21^{\text {st }}$ century, fashion students require a knowledge and practical use of technology to communicate in the ever increasing globalization of the fashion industry/apparel field. Through computer technology, workers connect with global partners for garment fittings, vendor communication, and production issues. Students who become familiar with this technology and its benefits will be better candidates for employment offers when they finish their studies (Medlin, Schneberger, \& Hunsinger, 2007). Colleges and universities can act as a conduit to prepare students to be competent in their use of this technology. Technology and interactions with experts can play a direct role in creating experiences for students in contexts that can be applied in the "real world" (Petersen, 2000).

\section{BACKGROUND}

With increasing availability and advances in technology, instructors have resources accessible to them, such as videos, DVDs and the Internet (Zarotsky \& Jaresko, 2000). These technology tools can dramatically impact how students are informed and educated. Use of the Internet affords many exciting opportunities for student learning, information, and interaction.

Videoconferencing is technology designed to connect parties that are not in the same physical location, in such a way that they can see and talk with each other in real-time. Videoconferencing technology has evolved from a time when the only place to conduct a 
videoconferencing session would be in a studio specially fitted with expensive equipment. Frequently, participants who wanted to be involved in a videoconferencing session had to travel far distances to find such a studio. Now with Internet capability, a computer, and a web camera, videoconferencing through the Internet, provides those same affordances to parties without having to travel past their own office or personal computer. This makes videoconferencing accessible to virtually anyone in a classroom or office with a computer, the Internet, and a web cam. Guest speakers from the apparel industry and fashion students can connect and interact via this medium with most of the benefits and fewer of the hassles formerly required for this type of interaction.

Having videoconferencing experiences in school can familiarize students with the concept, practice, and benefits of using this technology as a business communication tool. The fashion/apparel industry is highly globalized and communication with parties from all over the world is commonplace. Students would be prepared to work for companies who have vendors and manufacturers from around the world, who might communicate on a regular basis through videoconferencing (Paprika \& Ozcelik, 2007).

Videoconferencing technology can be used to bring guest speakers into the classroom without the guest speaker having to visit the classroom in person. Because apparel industry professionals are usually very busy, many times they do not have the time to travel to the classroom to act as guest speakers. Hindrances may include, for example, distance, travel and time limitations, and presentation issues. Arrangements for guest speakers to travel to school can be difficult logistically (Klemm \& Tuthill, 2003). If guest speakers desire to connect via Internet videoconferencing, the set-up for this arrangement could work in almost any classroom that has a computer, Internet connection, projection system, and a web camera. 
The guest speaker, who can be anywhere in the world, can engage and converse with the audience of students (Cogburn, n.d.). These guest speakers can help students to connect theory and practice. Students can interact with apparel industry professionals who can serve as mentors, role models, and content experts in their discipline. These experts can expose students to different perspectives on course content and can provide valuable networking opportunities (Weber \& Lieberman, n.d.).

Partnerships between the school and the apparel industry guest speaker can provide benefits for both the school and the industry professional partner. The school benefits by having resources (people) available to them who can disseminate current and relevant information (Pachnowski, 2002). The school also benefits by having professionals available to them who can influence curriculum and program direction (Pachnowski). The industry partner benefits by having the opportunity to interact with their possible "future" employees and develop a relationship with students who might serve as interns for their industry firm (Pachnowski).

\section{Problem Statement}

College or university instructors could benefit from the ability to invite an unlimited number of content area experts or apparel industry professionals as guest speakers into their classrooms. Instructors are not always experts in all aspects of their discipline. Instructors who have contacts with individuals, who may be experts in certain aspects of their discipline, could use these experts to help enrich their students' education and experiences. Sometimes these experts who might be willing to serve as guest speakers are not in a geographically 
common locality. The use of videoconferencing could make interaction possible between this industry professional guest speaker and the classroom.

Educators gathering at the 2007 Annual International Textile \& Apparel Association Annual Conference (ITAA) in Los Angeles, California, were able to choose to attend workshops about multimedia Internet-based learning experiences. Workshops entitled Current Issues in the Global Fashion Industry, Bringing Industry into the Classroom, and Around the World: Encouraging Global Cultural Study and Exchange were offered. ITAA is a professional organization of scholars, educators, and students in the textile, apparel, and merchandising disciplines in higher education (ITAA, n.d.).

Leading a discussion amongst various participants at ITAA, the researcher elicited comments from college/university instructors regarding the use of videoconferencing to connect their classrooms with apparel industry professionals. What was learned was that this technology was not widely utilized. Reasons offered for this lack of utilization included not knowing how to set up a videoconference and that they were too busy to "figure it all out." Some instructors thought the concept was excellent and one even offered her school as a pilot participant when she learned that the researcher had interest in researching this area. Currently, fashion students have interaction with the apparel industry professional through field trips, guest speakers physically visiting the classroom, and projects with firms in the industry.

The problem under investigation in this study is whether connecting the classroom and an apparel industry professional through the technology of videoconferencing using the Internet and a web camera can practically and cost effectively facilitate a positive and 
beneficial learning experience for students. Also being investigated is whether the participating apparel industry professional would also find this interaction beneficial.

\section{Purpose of The Study}

The purpose of this study is to explore the efficacy, benefits, and student perceptions of using Internet videoconferencing and a web camera to connect college and university fashion students with apparel industry professionals. Benefits described in the purpose statement is defined as content specific knowledge acquisition (Inaba \& Mizoguchi, 2004).

This is a multiple (three) case study using sets of partner participants which include the instructor/student set as the school partner and the apparel industry professional as the industry partner. This study has a threefold focus.

The primary focus will be how students report perceptions of their experience from the videoconferencing session with the apparel industry professional. If students benefit from the experience, more fashion instructors might be willing to employ this technology and have this experience in their own classrooms. Having more instructors setting up videoconferencing sessions with industry professionals could potentially help make students in the classroom more well rounded and knowledgeable about the industry and current business communication methods. The learning and professional engagement from interacting with real world professionals could make students feel more competent when they enter into the work world after their formal education.

The second focus will be to explore the instructor's perception of the videoconference experience. Instructors will reveal if student learning objectives can be met as a result of the 
videoconferencing experience. If a benefit to the instructor and students can be discovered, more fashion instructors might consider having this experience in their classrooms.

The third focus will be to explore how apparel industry professionals report perceptions from the experience of Internet videoconferencing with students. If a benefit to the apparel industry professional can be discovered, more apparel industry professionals might express an interest in becoming a partner with schools in this interaction.

This exploratory study hopes to reveal the nature of the developed process of using Internet videoconferencing with web cameras to connect fashion students with apparel industry professionals. It also hopes to allow the researcher to discover challenges or hindrances that exist within the set-up process. This study, additionally, hopes to suggest early generalizations within real world contexts and to provide a means by which this exercise of videoconferencing between college and university students and apparel industry professionals can be evaluated for effectiveness.

There are five research questions:

1. What are students', instructors', and apparel industry professionals' expectations before participating in an Internet videoconferencing session?

2. What are students' perceptions of their interaction with apparel industry professionals who visited the classroom via Internet videoconferencing?

2.1 Were student expectations met after the videoconferencing session?

2.2 How do the students rate the fashion industry professional's perceived personality traits?

2.3 What are the students' perception of the fashion industry professional's effectiveness and content knowledge?

2.4 How did technology impact the experience for the students?

2.5 What was the students' overall perception of the experience? 
3. What are fashion instructors' perceptions of the Internet videoconferencing experience between their students and apparel industry professionals?

3.1 Were instructor's expectations met?

3.2 According to the instructors, what session objectives were met?

3.3 How did instructors rate the technology of the session?

3.4 How did instructors rate student benefits of the session?

3.4 How did instructors rate the feasibility of the Internet session?

3.5 What was the instructors' overall perception of the experience?

4. What are apparel industry professionals' perceptions of interacting with fashion students via Internet videoconferencing?

4.1 How did apparel industry professionals feel that they benefited the students as a result of the videoconference session?

4.2 What was the apparel industry professionals' overall perception of the experience?

4.3 What factors motivate the fashion industry professional to participate in the Internet videoconferencing session?

4.4 What factors hinder the fashion industry professional in engaging in the Internet videoconferencing interaction with the students?

5. What are hindrances to setting up Internet videoconferencing guest speaking sessions in the college or university classroom?

\section{Significance OF THE STUdy}

Three audiences could benefit from the findings of this study. They include the apparel industry professional, the instructor, and the students of the instructor. If the findings from the study reveal benefit from the videoconferencing experience, these audiences could use the information as a justification for perusing additional Internet videoconferencing experiences. The apparel industry professional could benefit "socially" by being connected to 
and aware of what was happening in fashion education (Pachnowski, 2002). By interacting with students, the industry professional could get a pulse on what is happening in the classroom. These students may very well be their future employees and co-workers. The connection with the schools might foster their interest in becoming members of the school's advisory board committees where they could influence curriculum and directly influence students' career path and mentoring opportunities (Pachnowski).

Students would benefit by getting an "inside look" into the fashion world. They could find out about what it is like to work in the industry and learn the duties and responsibilities of various apparel employee positions. By having a beneficial videoconference experience with apparel industry professionals, students could have a head start with networking and knowing who to contact for employment leads.

The instructor would benefit by having support and alliance from the industry professional. The instructor could use this experience as part of a teaching strategy that could provide positive experiences for their students and the instructor could also have an additional teaching tool that could facilitate the connection between the school curriculum and the work world by connecting theory with practice.

This study could contribute to the body of research in this field by: (a) establishing a way that schools can be connected with apparel industry professionals; and (b) documenting any benefits or challenges of the videoconferencing interaction from the perspective of students, instructors, and the apparel industry professional.

Communication, interactional, and the acquisition of content knowledge are important aspects of the learning process. Using the technology of videoconferencing with Internet 
software and a web camera by college and university classrooms has the exciting potential to facilitate desired outcomes and has potential benefit for several stakeholders.

\section{DEFINITION OF TERMS}

The following definitions are provided to ensure understanding of their use throughout this study.

Apparel industry professional: Employee of an apparel industry firm or selfemployed person working in the apparel industry. In this study, the term may be used interchangeably with industry professional.

Bandwidth: "The quantity of information transmittable over an information channel" (AT\&T Knowledge Network Explorer, 2008).

Fashion students: Students enrolled in fashion design, fashion marketing, or other fashion related courses.

Globalization: An ideal in which there is a fully integrated, borderless world market which is controlled by individual firms without government intervention (Julius, 1997).

Guest speaker: For this study, the guest speaker is the apparel industry professional who was invited to connect with fashion students via Internet videoconferencing.

Internet connectivity: The capability to successfully connect to the Internet (AT\&T Knowledge Network Explorer, 2008).

Skype: A popular, proprietary, free VoIP system developed by Skype Technologies S.A. (Balint, 2007; Garfinkel, 2005; Holtz, 2005). It is one of several VoIP services available in the marketplace. 
Videoconferencing: Communication across distances by way of video and audio contact and includes a wide range of situations from live video lecturing, to point-to-point, individual-to-individual computer chats (AT\&T Knowledge Network Explorer, 2008; Coventry, n.d.).

VoIP-Voice over Internet Protocol (VoIP): One of services available in the marketplace (Holtz, 2005). With a VoIP system, two people can speak with each other by using computer connected headsets and microphones (Garfinkel, 2005).

Web camera: Device that can be connected to the computer to facilitate video communication and connection over the Internet. Used interchangeably with the term "Web cam" or "webcam." 


\section{CHAPTER 2}

\section{REVIEW OF LITERATURE}

The purpose of this study is to explore the efficacy, benefits, and student perceptions of using Internet videoconferencing and a web camera to connect college and university fashion students with apparel industry professionals.

Chapter 2 provides a review of the literature related to the topic of using guest speakers via videoconferencing in the classroom. The chapter will be divided into the following sections: School/Industry Partnerships, Guest Speakers, Videoconferencing in Education, Using Skype for Videoconferencing, Skype Studies, and Summary.

\section{SCHOOL/IndUSTRY PARTNERShIPS}

This section will discuss school/industry partnerships and their structure, benefits, and successful strategies. In this manuscript, school/industry partnerships are equivalent to classroom/industry partnerships.

\section{Benefits}

Dedmond (1991) states that regardless of the size or scope of the partnership, school/industry partnerships that are strategically planned, offer benefits to both parties. Working together, these partnerships have developed innovative approaches, some of which have influenced changes in school curriculum (Hirsch, 1992). 
Barnes, Morley, and Sayers (2002) report that during 1986, numerous schools became involved in establishing links between education and industry. Schools saw economic, social, and political benefits (Barnes et al.). Economic benefits occurred because students were vocationally prepared for enhancing industry, social benefits occurred because respect of industry occurred which encouraged positive attitudes toward working in industry, and political benefits occurred because there was a focus on the value to society of more young people being readily employable immediately out of high school (Barnes et al.).

Industry professionals (and industry firms) benefit by becoming acquainted with the types of students they will be hiring in the future (Hirsch, 1992). A benefit from that relationship might mean that firms or industry professionals that interact with schools might adapt (favorably) how they judge and view young job applicants (Hirsch).

Schools benefit by having industry professionals act as advisors, supporters, and mentors along with attracting financial support (Blais \& Adelson, 1998). These relationships can help the school achieve its educational mission (Blais \& Adelson). Schools can also benefit by having a relationship with an industry firm or professional who might contribute equipment to the school, provide for additional guest speakers, and provide work-study placements (Michielli, 2000).

Classroom instructors benefit by the ability to gain access to otherwise restricted resources, being able to keep up with developments in their field and by sometimes receiving recognition and support from the community (Dedmond, 1991). This partnership can also enhance the teachers' awareness on the relevance, application, and timeliness of what they are teaching (Michielli, 2000). Instructors may also benefit from the partnership by understanding industry's skill needs, acquiring contacts from within industry, providing an 
awareness of new trends or changes in industry, referral of appropriate guest speakers, and evaluation of curriculum from an industry perspective (Michielli, 2000).

Students benefit from school/industry partnerships by having the opportunity to expand their awareness of work and careers (Dedmond, 1991). Students can apply concepts to practical problems, and develop self-confidence from interaction with adults met in these interactions (Dedmond).

\section{Structure}

School/industry partnerships can be of several structures. Melville and Hawke (2002) identified factors that relate to school industry partnerships. They include: (a) the initiating source which may be the school, industry personnel, the enterprise, or the community; (b) the purpose for which the partnership is established, which may be to benefit the work-learning experiences of the students, to assist the economic development of the industry or community, or to mutually benefit both groups; (c) the location, which may be the school, the workplace, a third party, or a structured combination of all three; and (d) the management leadership of the program, which may be a single educator or a group of educators (or schools), an industry body, a community or regional organization, or a jointly operated management structure.

According to Melville and Hawke (2002), an organization called the Enterprise and Career Education Foundation supported structured workplace learning organized according to five different basic models. The models include: (a) educational models which are small and medium size enterprise/school-led models or single schools models; (b) industry models, which are any size enterprise/industry led models; (c) community or regional models, which 
are regional industry concentrations; (d) intermediary models, and (e) jointly-operated models.

This discussion focuses on the educational model of which there are several configurations. They include the small and medium size enterprise/school-led models: (a) cooperative or community clusters where a group of schools collaborate in the delivery of a workplace learning program, (b) community networks where a group of schools establish a networking arrangement, and (c) workplace delivery partnerships which are partnerships or clusters of schools with an established and effective work placement network (Melville \& Hawke, 2002):

For this dialogue, the single school model will be discussed with concentration on the general model (Melville \& Hawke, 2002). The general model involves a commitment to establish links to the community and often relies on the labor of dedicated teachers or on their principals (or in the higher education, deans) to support instructors in their efforts to develop contacts with employers (Melville \& Hawke).

One partnership strategy is the internship, which enables students to assume a position with an organization for a specified period of time and receive school credit (Adams, n.d.; Bengtson, 2006; Dedmond, 1991). The aim of the internship is for students to gain work experience and develop an enhanced understanding of the industry while undertaking work that is of value to the host organization (Adams). Students find internships rewarding. Adams" study gives an account of the South Australian School of Art Arts Industry Internship Program, which gave undergraduate students the opportunity to intern with an arts organization or business. 
One of the students who was chosen for the internship opportunity said that the placement had been the most beneficial thing he had done (Adams, n.d.). Another student commented that the internship had given him his first taste of real world experience (Adams).

In addition to internships, additional partnership strategies can include arrangements for students to handle outside projects with the company and/or to receive specialized training (Bengtson, 2006). Partnerships can also include the presentation of lectures or teaching series from the industry firm's employees (Bengtson). Other types of school/industry partnerships include shadowing, mentoring, youth service, and job placement programs (Dedmond, 1991).

\section{Strategies}

Successful school/industry/ partnerships are based on effective strategies (Dedmond, 1991). Collaborative planning is often considered the single most needed element for successful school/community relationships programs and activities (Dedmond). The choice of leadership from each sector of the partnership is among the most important considerations (Dedmond). Building a program on carefully determined needs facilitates establishing needed competency measurements and performance objectives (Dedmond).

Keitel's (n.d.) study was aimed at the development of a model of partnership between a higher education institution and industry. From six partnership cases, a model emerged (Keitel). The partnership from Keitel's study was a call center. This relationship arrangement was defined as formal, collaborative, and mutually beneficial where resources were shared, trust and respect initiated and sustained to ensure a consistent source of qualified industry ready personnel and employment opportunities for students (Keitel). The partnership model's 
major categories included causal conditions, contextual conditions, initiating strategies, sustaining strategies, and consequences (Keitel).

The causal conditions are the events that triggered the development of the partnership (Keitel, n.d.). The contextual conditions refer to the conditions in which the partnership is situated (Keitel). The initiating strategies refer to the actions deliberately aimed at starting the partnership, while the sustaining strategies refer to actions and responses that occur as the result of the partnership (Keitel). Finally, the consequences are the outcomes of the strategies and the facilitating conditions (Keitel).

In Keitel's (n.d.) study, the causal conditions that prompted the formation of the call center/school partnership were the felt needs experienced by both parties. The call center industry looked at higher education institutions as sources of qualified manpower for their business operations and the school looked forward to having on-the-job training exposure for their students as well as the opportunity to conduct a training program for faculty who would implement the curriculum (Keitel). Strategies to initiate and sustain the partnership were employed, with the goal of realizing mutually beneficial consequences for each partner.

The contextual conditions refer to the conditions in which the partnership is situated. In this study, the industry partners were two separate entities, the higher education institute and the call center. The contextual condition examines who is in charge of initiating the partnership. In other instances, both partners belong to the same company and a relationship is already assumed.

Initiating strategies are described by Dedmond (2001) and include nine steps:

1. Start small.

2. Design a specific program in response to a particular need. 
3. Survey community resources by checking with other educators, chambers of commerce, retail merchants associations, private industry councils, and professional organizations to identify potential partners.

4. Define and design the partnership to correspond with other processes such as educational performance appraisals and educational standards and philosophies.

5. Obtain management support and plan partnership activities.

6. Establish program effectiveness indicators.

7. Implement plans.

8. Conduct periodic evaluations and report results.

9. Decide to continue, revise, or terminate the plan.

Sustaining strategies are employed once the partnership is formed. Methods to sustain the partnership may include a third party who may or may not have participated in the initiation of the partnership (Keitel, n.d.). Strategies may also include instructor or employee training, incentives for students including scholarships or part-time jobs and first considerations for full-time jobs after graduation (Keitel). Also documentation may be drawn up which may spell out the responsibilities for each partner (Keitel).

The consequences for the partners of Keitel's (n.d.) study were mutually beneficial. The need to have qualified candidates for employment (call center needs) was met along with giving the students first priority in the recruitment effort (student needs). Keitel's study concluded that the employment opportunities for graduates was the foremost benefit derived from the partnership.

According to Keitel's (n.d.) study, the answers to several questions are needed in order to evaluate the success in establishing a viable partnership. The questions are: (a) what are the factors that caused the formation of their partnership? (b) what criteria were used in 
the choice of the partner institutions? (c) what strategies were employed to start and sustain the partnership? (d) what conditions, if any, have influenced the employment of those strategies? and (e) what have been the consequences or outcomes of the partnership?

From the six partnership cases examined by Keitel's (n.d.) study, the following inferences were drawn: (a) there were common causal conditions that triggered the formation of the partnerships; (b) the partners, whether by themselves, or with the help of a third party, had the capability to establish and sustain the partnership; (c) school/call center partnerships were beneficial to both parties, and most especially to the students and graduates of the school partner; and (d) the facilitation of a third party contributed to the strengthening and continuity of the partnership.

Finally, based on the results of Keitel's (n.d.) research of comparison with the relevant literature, it was inferred that the model of the school/call center partnership developed in this study had external validity. A recommendation for future research was suggested to further validate and to extend the model.

\section{GUEST SPEAKERS}

When college students are given the opportunity to explore career choices, research revealed that they tend to have more clarity and make more realistic decisions about their careers (Lane, 1977, as cited in Threlkeld, 1935). College career orientation courses (also sometimes called career opportunity classes or career survey classes) can help students develop accurate perceptions of their field of interest and can help them determine career goals (Cockrell, 2002). Cockrell, in a study with the purpose of determining nursing career perceptions of prenursing students enrolled in a university prenursing program, found that 
most students were unclear about their perceptions of that profession. A Cockrell-Punter Nursing Perception Scale Instrument was used for data collection in that study which measured the nursing perceptions of 207 students. Cockrell also found that direct experience enhances the ability of students to make career decisions and the stability of that decision and that direct experience with healthcare experts impacted student decisions about nursing.

Industry professionals acting as guest speaker experts can be a valuable resource to students who are exploring career options. Guests can help build student interest in the subject matter (Pajares, 2004). Professionals that actually work in "the field" can provide realistic perceptions of what a particular employment position entails.

Guest speakers can serve as professional role models for students (Sniezek, 2005). The concept of social modeling (explained by psychologist Albert Bandura) refers to behavior changes resulting from the observation of a model (Pajares, 2004). Pajares suggested that modeling affects motivation by instilling behavioral outcome expectations. This especially true when the model is someone who is significant to the observer, i.e., a purposed expert or someone who is effective at doing what the observer would like to see in his own life (Mikulas, n.d.). Consequently, in serving as role models, these guest experts can have an important influence on their student audiences.

Students' direct experiences with professionals can be accomplished by having guest experts come into the classroom as guest speakers. Research shows that guest speaker visits are beneficial for improving student learning and making connections between school and the work world (Sniezek, 2005; WGBH Educational Foundation, 2006). Guest speakers can enhance student learning and foster connections between academia and the practitioner and can supply information that is cannot typically be found in a textbook (Metrejean, Pittman, \& 
Zarzeski, 2002; Sniezek, 2005; WGBH Educational Foundation, 2006). In Metrejean et al.'s (2002) study which outlined a guest speaker event which occurred in several junior-level accounting classes, guest speakers were called a "specific tool" to enhance the educational experiences of accounting students. Guest speakers increase student confidence in career choices, help prepare students for job interviews and provide opportunities for informal networking with professionals (Metrejean et al.).

There are many sources of guest speakers. In Metrejean et al.'s (2002) study, a database of local professionals were identified. Suggestions for developing the database included contacting advisory board members, professional societies, trade association listings, alumni directories, and academic staff and student referrals along with former students (Metrejean et al.).

There are strategies that maximize the benefits of guest speakers. In Metrejean et al.'s (2002) study, the guest speaker event followed a set of sequences. Prior to the guest speaker coming to the school, the instructor gave students a short biography of the speaker's education and career background (Metrejean et al.). With that information, students were instructed to develop two written questions for the speaker to address during the event (Metrejean et al.). The students e-mailed their questions to the instructor, who sorted the questions into categories (Metrejean et al.). The questions were then sent to the speakers so that they discovered students' interests (Metrejean et al.). These questions helped to ensure that the speakers addressed issues that were of interest to the students (Metrejean et al.). Students' written responses to a survey which was administered for feedback after the event were summarized into four categories including: (a) career choices, (b) motivation, (c) r22eal world experiences, and (d) event specific experiences. 
Finding experts who are able to come to the classroom as a guest speaker can sometimes be problematic. These potential guest speakers are sometimes prevented from coming into the classroom physically, because of time commitments and logistical constraints (Penn State, n.d.). In other instances, budgets do not provide funds to accommodate travel costs to the classroom nor the cost of lodging for a guest speaker (Penn State).

Rowland (2007) conducted a study of a guest lecturing program set up by a School of Marketing at an Australian University. This program established relationships between the marketing school and marketing corporations with the purpose to improve the students' knowledge of contemporary business practices and career prospects (Rowland). Corporations were asked to deliver a problem based learning lecture (Rowland). Funding was obtained to establish a group who arranged and coordinated guest lecture appearances. Eighty students who attended a Consumer Behavior guest lecture completed a questionnaire at the end of the lecture (Rowland). An in-depth interview was conducted with the guest lecturer where students were asked whether they had expectations of the guest lecturer (Rowland). Sixty percent of students who indicated they did have expectations of the lecturer were asked to list those expectations. They listed comments in reference to expecting to learn about real-world/practical applications, they anticipated presentation style, and hoped that the lecture would help with their assessment tasks. They also expected that the guest lecturer might be engaging and interesting. Some thought that the guest lecturer might promote their company (Rowland).

Eighty-three percent of students had their expectations met by the guest lecturer (Rowland, 2007). The main categories which emerged in the responses directly expressed 
that expectations had been met by $64 \%$ of the students. Comments stated that the guest lecturer was "helpful," "engaging," "well prepared," "knowledgeable," and other related positive comments. A few (5\%) of the comments were slightly negative in nature (Rowland).

Rowland's (2007) study revealed that $98 \%$ of the students felt that the guest lecturer helped them gain a better understanding of how marketing concepts are applied in "real-life" situations; $86 \%$ indicated that the guest speaker inspired them to learn more about marketing careers; $99 \%$ considered the guest lecture to be a positive experience, while $96 \%$ expressed that they wanted more guest lecturers.

The guest lecturer's perspective of the session was also positive, seeing this as an opportunity to "give something back" to the students and to his profession as a whole (Rowland, 2007).

Methods by which the guest lecturers were recruited in Rowland's (2007) study included: (a) personal contacts, (b) former students and alumni, and (c) cold-calling. The availability of lecturers was limited by the lack of incentives and a lack of established contacts.

\section{VIDEOCONFERENCING IN EDUCATION}

Bringing guest speakers into the classroom virtually is now possible with the technology of videoconferencing. Various delivery methods to bring these virtual guest speakers into the classroom have been used with success in distant and online courses. Varvel (2001) and Cotlar \& Shimabukuro (1993) agree that computer mediated communication in education can improve the quality of instruction. One such technology is videoconferencing. Videoconferencing used effectively in the traditional classroom could facilitate interaction 
between experienced experts and students. Students could have almost unlimited access to professionals from around the world which could broaden their perspectives and create networking opportunities.

Videoconferencing was first introduced in 1964 and was mainly used for business communication (Roberts, 2004; Video Conferencing History, n.d.). Use of this technology served as a way to have parties speak to and see each other in real time (synchronous) regardless of the distance between the two parties.

The year 2003 saw a rise in the use of videoconferencing for off-campus classrooms (Roberts, 2004). Interactive classrooms became more fashionable as the quality of streaming video improved and the former transmission delays decreased (Roberts).

Isaacs and Tang (1993) conducted a case study with the goal of understanding how to make effective use of video in a remote collaboration. They compared a small team's interactions through a desktop videoconferencing prototype with face-to-face interactions and telephone phone conversations (Isaacs \& Tang). It was found that compared with audio only, a video channel adds or improves the ability to show understanding, forecast responses, give non-verbal information, enhance verbal descriptions, manage pauses, and express attitudes (Isaacs \& Tang). Compromises to using video over face-to-face meetings were noted which included the inability to control the floor, to have side conversations, and difficulty in noticing peripheral cues (Isaacs \& Tang). The authors felt that when weighting these disadvantages with the ability to connect with people not formerly available due to time, budget, and distance constraints, videoconferencing can be a valuable alternative to face to face meetings (Isaacs \& Tang). 
Earlier, videoconferencing's practicality in the classroom was inhibited by the requirement of expensive equipment and high connecting costs (Video Conferencing History, n.d.). Some schools have dedicated facilities for videoconferencing that link directly with other videoconferencing outfitted classrooms in other locations. These classrooms and the necessary equipment are expensive to build and maintain. For example, in Lim and Freed's (2009) study to identify concerns of educators currently involved in videoconferencing, 34 educators posted comments online. Teacher concerns and administrative support were the major areas of discovery. One comment from a distance learning coordinator was that they had a wonderful $\$ 125,000$ room, with a $\$ 2,500$ a month connect charge.

In research conducted on virtual guest speakers, several "for future study" recommendations emerged. While Cotlar and Shimabukuro (1993) studied the use of electronic guest lecturers to stimulate student and guest speaker interaction, Kumari (2001) studied an experience in a graduate course where three virtual guests were invited to interact with students in the classroom. Their studies suggested a need for additional research to uncover students' individual perceptions of the benefits of virtual guest speakers, to study how students benefit from active involvement in dialogue with guest experts, to evaluate students' reactions to the virtual guest experience, and to discover the value attached to these interactions (Cotlar \& Shimabukuro; Kumari). This study addresses these study recommendations.

Several software programs are now available that can be used to bring the videoconferencing experience into the classroom using the Internet with very little or no cost. Internet-based software has emerged as a practical and inexpensive alternative to building and maintaining videoconferencing studios. 
In a study by Tabata and Johnsrud (2008), 4,534 individuals (full- and part-time faculty, lecturers, and graduate assistants) were surveyed to examine faculty participation in relation to their technology use, attitudes toward technology and distance education, and their adoption of innovations at a public postsecondary, 10-campus system. The findings identified core issues underlying faculty participation and non-participation in distance and related education including videoconferencing. The findings indicated that faculty participation was associated with their skill in using technology, their attitude toward technology and distance education, their adoption of innovations, and the demographic variables of age, ethnicity, and institutional affiliation. Having a positive attitude and knowledge of the technology of videoconferencing can help students begin to understand the thought processes of experts and thus enhance their educational experiences and critical thinking skills (Petersen, 2000).

Two positive comments made by K-12 teachers in Lim \& Freed's 2009 study which had the purpose of identifying K-12 educator concerns of those involved in videoconferencing. included: "I have learned a lot of wonderful things, and I hope to be making videoconferencing a regular part of my curriculum ...," and "... it is in the use of videoconferencing that teachers become aware of the possibilities to enhance their curriculum" (p. 439).

Educational uses of videoconferencing is growing. Daley, Spalla, Arndt, and Warnes (2008) conducted a study on a teaching-learning strategy using videoconferencing between university nursing students in the United States and in the United Kingdom. Study objectives centered around diversity, technology, communication, and collaboration and experience of novel educational approaches (Daley et al.). A Likert scale questionnaire was used to gather data about the experience with the results that students were very positive about the 
experience, stating that the experience enhanced their learning, exposed them to diverse thinking, increased their ability to collaborate, and made them more likely to work with others in their nursing careers (Daley et al.). These students, though, were critical of technology. They pointed out issues of pixilation, echo, feedback, and delay in auditory feed (Daley et al.).

Zerr and Pulcher (2008) conducted a pilot study in 2008 which analyzed the benefits of using interactive technology with nursing professionals who evaluate graduating senior nursing students during a university Leadership Assessment Day. The purpose of the study was to determine whether videoconferencing technology promoted recruitment and retention of these nursing professionals without compromising student learning (Zerr \& Pulcher). The advantages and disadvantages of using interactive videoconferencing technology in education were discussed (Zerr \& Pulcher). A convenience sample of four volunteer students were asked mock questions by the nursing professionals and quantitative data was collected as well as Likert scale responses (Zerr \& Pulcher).

The results indicated that interactive videoconferencing is an effective, accepted format for educational opportunities (Zerr \& Pulcher, 2008). Students were satisfied with the audio component of the videoconferencing, stating it was adequate to communicate efficiently and effectively (Zerr \& Pulcher). The students also strongly agreed that interactive videoconferencing was a comfortable method of interaction (Zerr \& Pulcher). Additionally, all four students highly recommended the continued use of this method for the Leadership Assessment Day (Zerr \& Pulcher). One student commented, "I felt I was less nervous [than] I would have been if I [were] in the assessor's (professional's) presence" (p. 90). Another student commented that it was fun and interesting and a great way to communicate and 
educate upcoming registered nurses or nursing students (Zerr \& Pulcher). One of the professionals that interacted with the student commented, "What a great idea. I felt like I could give encouragement and feedback as if I were in the room. I see this being a big part of the assessment process for future classes" (p. 90).

Sedgwick and Spiers (2009) conducted a study with the purpose of describing the experience of nursing students and mentors during a hospital-based clinical practicum. Videoconferencing technology was used for conducting in-depth qualitative interviews between students and mentors (Sedgwick \& Spiers). The authors concluded that videoconferencing provided them with a cost-effective alternative to in-person interviewing (Sedgwick \& Spiers). As a result of the study, they recommended the use of higher bandwidth connections when using videoconferencing technology since they generally resulted in greater satisfaction with the videoconferencing experience (Sedgwick \& Spiers). Low bandwidth resulted in poorer image quality and transmission lag (Sedgwick \& Spiers). This was evidenced where sudden movements appeared jerky and blurred (Sedgwick \& Spiers). Also, at times during the interviews, the participant's face was less clear depending on the camera angle and how the person was sitting, reducing the ability to see the participant's facial cues and to establish eye contact (Sedgwick \& Spiers). Sedgwick and Spiers also reported on issues with setting up the videoconferencing sessions. Before a service was established, there was a need for several contacts to confirm the videoconference session bookings and to perform a test run to ensure connection stability (Sedgwick \& Spiers). Setting up the videoconference was time intensive, taking a few days to a few weeks to confirm the booking and then even after confirmation, a short notice cancellation took place because of higher priority meetings (Sedgwick \& Spiers). 


\section{USING SKYPE FOR VIDEOCONFERENCING}

When businesses wanted to communicate via videoconferencing they had to either build a videoconferencing studio or travel to a studio to connect with other businesses. With the availability of high-speed ("broadband") Internet connectivity, which now makes this technology available for anyone, the masses are now using this technology to communicate with their friends and family (Garfinkel, 2005). This technology uses the Internet for voice telephony and is called Voice over Internet Protocol (VoIP; Garfinkel).

Today's technology uses a VoIP system. VoIP can be defined as a telephone service which is delivered through the computer (Holtz, 2005). With a VoIP system, two people can speak with each other using headsets and microphones connected directly to their computers (Garfinkel, 2005). VoIP systems take independent digital streams, compresses them and breaks the streams into packets, and sends those packets over the Internet (Garfinkel, 2005). Several VoIP services are available in the marketplace.

One of the more popular VoIP services is Skype. Skype is a proprietary VoIP system developed by Skype Technologies S.A. (Garfinkel, 2005). The company was founded by Janus Friis and Niklas Zennstrom (Garfinkel). Within Skype's first week of operation in August 2003, over 60,000 people downloaded the Skype client (Garfinkel). In October 2004, Skype's creators boasted of more than a million users (Garfinkel). A market research company predicted that in 2008 , worldwide users were expected to be between 140 million and 245 million (Garfinkel, 2005; Holtz, 2005).

Skype offers several services including VoIP which allows two Skype users to establish two-way audio streams with each other (supports audio conferences of up to four users), IM which allows two or more Skype users to exchange small text messages in 
real-time, and the ability to search and file transfer (Guha, Daswani, \& Jain, 2006). One of Skype's software features is its ability to be used for video chat or videoconferencing (Balint, 2007). Twenty percent of its 171 million registered users make video calls using Skype (Balint). Skype is free or very inexpensive to its users because the video and audio travel over high-speed Internet connections (Balint). Previously these connections traveled over telephone lines (Balint). Skype software and use of the Skype network is free except for a nominal charge for calls made using the "Skype Out" and "Skype In" features that connect Skype to the world-wide Public Switch Telephone Network (Garfinkel, 2005). Skype is free of adware and spyware and does not get its revenue from advertisements (Garfinkel). With Skype, the caller and the person on the receiving end only need a computer, a web camera, microphone, and Internet access (Balint). Many web cameras that are sold separately are bundled with videoconferencing software (Balint). Most home videoconference users use their web cams to visit with distant family members (Balint).

Skype is based on peer-to-peer technology (Garfinkel, 2005). While some services transmit voice calls through a central server, Skype, users seek other Skype users. Additionally, based on the users, a searchable network is built and other users can send messages (Garfinkel). Skype is available for Windows, MacOS, PocketPC and Linux (Garfinkel).

\section{Benefits}

The two main benefits of Skype are its quality and its cost (Holtz, 2005).The basic software is free and can be downloaded within a few minutes from the Skype website (Holtz). 
In the area of quality, Skype is distinct from most other VOIP services in that it is a peer-to-peer (P2P) application (Holtz, 2005). Since there are no servers, the community of Skype users share the computing power from their own computers to process information (Holtz). The reliability of the Skype service exceeds that of a regular telephone (Holtz, 2005). Since the sound is delivered digitally rather than through the analog process, the quality of the audio is near quality of a CD (Holtz). Skype's excellent voice compressor gives fidelity that can surpass traditional telephone systems when used with a high bandwidth connection (Garfinkel, 2005). One exception to this rule appears to be when Skype is used over an 802.11 wireless network where in this case, voice quality suffers considerably (Garfinkel).

Two recorded uses by Skype include a deployed soldier who watched the birth of his baby over a web camera and a couple who lived in different states who "dated" via Skype's videoconferencing service (Balint, 2007).

\section{Security}

Skype claims to encrypt (scramble) all its communications (Garfinkel, 2005). They do this with a 128-bit or better cryptography ciphers, which makes it impossible for someone who passively intercepts a Skype conversation from deciphering or listening to its contents (Garfinkel). The overall security of a Skype conversation depends on many factors, including the security of the computer and network on which Skype is running (Garfinkel). Because Skype is a peer to peer system, the overall security can be affected by third parties that are in the network (but unknown to those in a particular phone conversation). The Skype program can update itself each time it runs and so the security over the overall system can change without warning (Garfinkel). Since the Skype protocol is both proprietary and secret, the only 
sources of security information are from statements from the company itself and also what can be learned by reverse-engineering the software (Garfinkel).

\section{Requirements for Use}

Skype is very easy to use. It requires a high-speed Internet connection, installed Skype software, and equipment to talk and listen (Holtz, 2005). To talk and listen, one can use a USB microphone or built in microphone and set of speakers or a headset that integrates headphones and a microphone, or even a regular-looking telephone handset that plugs into a USB port (Holtz). Every Skype user has a username and a password and each username has a registered e-mail address (Garfinkel, 2005). To log into the Skype system, the user must provide their username and password (Garfinkel). Other than choosing a username, no other configuration is required (Garfinkel); as long as the individual being called also has the same required equipment, one can call anyone anywhere in the world and talk as long as desired at no cost except for the normal Internet service fee (Holtz).

When downloading the Skype software to a computer, one must make sure that the computer is free of all spyware, adware, remote-control programs, worms, and computer viruses (Garfinkel, 2005). All PCs running the Windows operating system should be equipped with an up-to-date anti-virus and anti-spyware program (Garfinkel).

Given the cost, ease of use, and availability, Skype software can be used quite practically to host videoconferencing sessions between an apparel industry professional and the classroom. 


\section{SKYPE STUdiES}

Ryobe (2008) conducted a study which examined how video chat activity between Japanese students and online Filipino English teachers through Skype improved students' oral communication skills and motivation toward autonomous learning. Fifty-five university students engaged in 25-minute video chats and were interviewed and questioned via surveys about their perceptions and attitudes. The results revealed better performances than a previous 40 students who had engaged in voice chats in an earlier year. The study revealed that one drawback to using Skype for classroom use is that of sound quality, which was poorer in a university environment than at home. Additionally, sound and video image problems occurred frequently in Ryobe's study. In summary, $100 \%$ of the video chat students' open comments were positive compared to $90 \%$ of the voice chat groups that were conducted in the previous year.

Some comments from the students who were a part of the video chat group included: "This Skype class was fun and useful even if it was frequently interrupted by faulty connections and sound problems" and "Talking ... via Skype is valuable amusing time and a great experience" (Ryobe, 2008, n.p.).

Another study (Paprika \& Ozcelik, 2007) was conducted to test a teaching module that brought out emotions and emotional awareness. The participants were students from a Hungarian Budapest and an American university. The results of the study suggested that videoconferencing was a viable tool "to create real-time interactions between students in different countries in which they can experience, express, and observe emotions" (n.p.) 


\section{SUMMARY}

A review of the literature related to the purpose of this study revealed that school/industry partnerships are very important strategies that hold benefit for both the industry partner (apparel industry professional) and the student/school partnership. Various models have been developed to help partners maximize the benefits of this collaboration. Guest speakers have been shown to be an excellent resource that can benefit both the students and the instructor. Guest speaker benefits are maximized when well planned strategies are executed. The problem of access to valuable guest speakers or experts can be mitigated when these speakers visit the classroom through the use of videoconferencing technology. Videoconferencing was essentially unavailable to the classroom because of its high cost and logistical concerns. Now, with the use of Internet software programs, this communication technology and its benefits can be easily available to all classrooms with a minimal amount of equipment. Skype, a proprietorial software program used on the Internet, is a vehicle by which instructors can link to guest speakers and industry professionals. Skype's benefits surpass other VoIP services with its low cost and high quality components. Using Skype can facilitate the interaction between the apparel industry professional and the classroom. Giving students maximum exposure to current technology will help them be more aware of how the business world works and can give them maximum networking possibilities. 


\section{CHAPTER 3}

\section{METHODOLOGY}

The purpose of this study was to explore the efficacy, benefits, and student perceptions of using Internet videoconferencing and a web camera to connect college and university fashion students with apparel industry professionals.

This study had a threefold focus. This was a multiple (three) case study using sets of partner participants which included the instructor/student group as the school partner and the fashion industry professional as the industry partner. This study examined perceptions from the perspective of instructors, students, and fashion industry professionals. There were five research questions:

1. What are students', instructors', and apparel industry professionals' expectations before participating in an Internet videoconferencing session?

2. What are students' perceptions of their interaction with apparel industry professionals who visited the classroom via Internet videoconferencing?

2.1 Were student expectations met after the videoconferencing session?

2.2 How do the students rate the fashion industry professional's perceived personality traits?

2.3 What are the students' perception of the fashion industry professional's effectiveness and content knowledge?

2.4 How did technology impact the experience for the students?

2.5 What was the students' overall perception of the experience?

3. What are fashion instructors' perceptions of the Internet videoconferencing experience between their students and apparel industry professionals? 
3.1 Were instructor's expectations met?

3.2 According to the instructors, what session objectives were met?

3.3 How did instructors rate the technology of the session?

3.4 How did instructors rate student benefits of the session?

3.4 How did instructors rate the feasibility of the Internet session?

3.5 What was the instructors' overall perception of the experience?

4. What are apparel industry professionals' perceptions of interacting with fashion students via Internet videoconferencing?

4.1 How did apparel industry professionals feel that they benefited the students as a result of the videoconference session?

4.2 What was the apparel industry professionals' overall perception of the experience?

4.3 What factors motivate the fashion industry professional to participate in the Internet videoconferencing session?

4.4 What factors hinder the fashion industry professional in engaging in the Internet videoconferencing interaction with the students?

5. What are hindrances to setting up Internet videoconferencing guest speaking sessions in the college or university classroom?

This chapter describes the research design, participants, instruments, procedure, data analysis, and limitations of this study. This was an exploratory study.

\section{ReSEARCh Design}

This study adopted a mixed methods qualitative and quantitative method approach. The qualitative portion was analyzed by finding common themes and trends while the quantitative data was computed with statistics. Creswell (1998) believes that there are several compelling reasons for using a qualitative approach. The reasons include the nature of the 
research question(s) (Creswell). Some of this study's research question starts with a "how." Creswell believes that if a topic needs exploration, a qualitative approach is indicated. Creswell also recommends a qualitative study when one wants to present a detailed view of a topic and when individuals are studied in their natural settings.

According to Leedy and Ormrod (2001) and Isaac and Michael (1997), qualitative research focuses on phenomena which takes place in natural settings. Isaac and Michael refer to this research as naturalistic inquiry. In this study, the natural setting was the school classroom. Isaac and Michael state that in naturalistic inquiry, the primary instrument is the human. In a qualitative study, the outcomes can show multiple realities which is differentiated from a quantitative study where only one reality is established (Isaac \& Michael). Peshkin (1993, cited in Leedy \& Ormrod, 2001) states that qualitative research serves several purposes. These purposes include description, interpretation, verification, and evaluation (Peshkin, in Leedy \& Ormrod). This study hoped to reveal the nature of the developed process (description); allow the researcher to discover and explain any benefits and challenges that exist within the phenomena (interpretation); develop generalizations within real world contexts (verification); and provide a means by which the phenomena can be evaluated for effectiveness (evaluation). Additionally, quantitative methodology will be used for data analysis from the Likert scale data collected. The three cases were compared among and between cases. Predicting or explaining cause and effect relationships suggests a quantitative research design (Leedy \& Ormrod).

The qualitative research design that was used for this study was the case study. Leedy and Ormrod (2001) point out that in a case study, an event is deeply studied for a particular period of time. The case in this study consisted of the school partner (instructor and his 
students) and the apparel industry professional (industry firm representative). Three cases were studied. This multiple case study explored the experiences of school and industry partners working together to bring a videoconferencing session to fashion students. The multiplicity of the case study allowed for comparisons, theory building or proposed generalizations, and can be used to provide preliminary support for hypothesis (Creswell, 1998; Leedy \& Ormrod).

Isaac and Michael (1997) stated that the preferred mode for naturalistic inquiry is case study because of its adaptability to multiple realities. Even though, according to Isaac and Michael, naturalist inquiry studies have findings that are likely to be regarded as tentative, the findings in this study provided a body of knowledge from which to launch other studies.

The concept of creditability for the case study explains criteria for establishing trust, confidence, and believability in research results (Isaac \& Michael, 1997; Lincoln \& Guba, 1985). Lincoln and Guba suggest several techniques that will be employed in this study to assure credibility of research:

1. Prolonged engagement which means being present where the study is being performed long enough to build trust, experience the depth of variation and to overcome distortions.

2. Triangulation which is the verification of findings through:(a) multiple sources of data, (b) using multiple methods of data collection, and (c) acquiring observations from multiple researchers. Several sources will confirm findings at different points in time.

\section{Participants}

There were three groups of participants in this study. They were school instructors, the instructors' students, and the apparel industry professionals which may or may not have represented a firm. These three participants were divided into two groups: the instructor and 
his students who constituted the first group which will be referred to as the school partner and the apparel industry professional who will be referred to as the industry partner.

Isaac and Michael (1997) stated that the data sampling method most appropriate for naturalistic studies are purposeful samples. These are designed to understand the individual case(s) exclusively and not to generalize to a population (Isaac \& Michael). Patton (as cited in Isaac \& Michael) states that in this type of sampling, one must select "information-rich cases." Convenience sampling is one type of purposive sampling that Isaac and Michael describe as using a sample that is easily available. Although Isaac and Michael state this is the weakest of other types of purposive samples, convenience sampling is essential for this study since the participants' interest in the project and their availability is vital to conducting the research.

Participants were chosen from a convenience sample. The schools were selected from several sources including researcher acquaintances, referrals, and interest inquiry open invitations. The industry partner was chosen from a list of referred apparel industry professionals who showed interest in being a part of the study as well as referrals through online professional networks. The schools and the industry partner professionals were invited to participate through respective Instructor Invitation to Participate in Research Study letters (Appendix A) and Industry Professional Invitation to Participate in Research Study letters (Appendix B). The schools who responded affirmatively to the invitation were considered as one of the school partners in each of the sets of participants. The apparel industry professionals (industry partner) were chosen based on the requests of the instructors. The Instructor's Pre-Survey (Appendix C) asked instructors to choose the employment position of the guest speaker industry professional that they wanted to interact with their class. The 
researcher acted as a coordinator and liaison between the school partner and the industry partner professional and developed notes of the interactions and set up.

\section{INSTRUMENTS}

Leedy and Ormrod (2001) and Creswell (1998) stated that methods of data collection for the qualitative portion of studies should include observations, interviews, appropriate written documents, and/or audio-visual material. The data collection focused in three areas:

(a) student's perception and experience of the videoconferencing session, (b) instructor's perception and experience of the videoconferencing session, and (c) apparel industry professional's perception and experience of the videoconferencing session.

The instrument used to recruit the instructor/school participants was the Instructor Invitation to Participate in Research Study document (Appendix A). A similar document, Industry Professional Invitation to Participate in Research Study (Appendix B), was sent to apparel industry professionals to invite them to become a part of the study. Both documents were sent via e-mail.

Please note that all study instruments located in the Appendices reflect what was sent/given to study participants. The research questions found on the consent forms and invitations have since been revised/reworded for greater clarity. The revised/reworded research questions appear in the body of this manuscript.

Researcher observations included notes on each of the three interactions of the three cases with the school and the industry partner.

The instruments were developed by the researcher partially based on instrument items found in literature based on guest speakers. In Rowland's (2007) study on guest lecturers, 
survey items asked students to comment on guest lecture expectations. Some of the statements about student, instructor, and industry professional expectations for this study were found in Rowland's study. The instruments for this study were piloted in December 2008, and a few questions/statements, for better clarification of findings, were added or rephrased as a result.

There were two instructor study instruments. The first was the Instructor's Pre-Survey (Appendix C) which collected demographic and profile information on the school and on the instructor. This 20 -item on-line survey ascertained the instructors' experience with computer technology, guest speakers, session expectations, and student learning objectives that could be met during the session. Instructors were given the opportunity to request a guest speaker industry professional from several different areas. They were also asked if they needed a researcher-supplied web cam. Questionnaire elements included open-ended questions, Likert scale statements, and multiple choice items.

The second instructor instrument was the Instructor Post-Survey (Appendix D) which was entitled Instructor's Assessment of Videoconferencing Experience—Post Session Questionnaire. This survey was completed in the classroom, immediately after the videoconferencing session. This questionnaire uncovered the instructors' perceptions of the experience and asked for areas of suggestions or improvement for future videoconferencing experiences. This 47 -item questionnaire asked the instructors to choose responses from a 5point Likert scale ranging from strongly disagree to strongly agree on various statements about expectations, perceptions of perceived speaker personality traits, presentation content and effectiveness, technology, session objectives, and feasibility. Additional open-ended questions asked instructors about what they liked best and least about the session, how they 
described the session in one word, how they would find guest speakers to conduct additional videoconferencing sessions, and in what other ways they could use videoconferencing to benefit their students. The instructors were also given the opportunity to share other issues, suggestions, or questions about the experience.

There were two student instruments. The first instrument was the Student Pre-Session Survey (Appendix E), which was a paper survey with three Likert scale statements for students to rate their level of agreement. The survey also contained one open-ended question which asked the students to list the most important thing they wanted to gain out of the videoconferencing experience. This survey was completed by the students right before the videoconferencing session.

The second student instrument was the Student Post-Session Survey (Appendix F) which was entitled Student Assessment of Post Video Conferencing Experience. This 60item paper questionnaire was given to students immediately after the videoconferencing session. Questions 1 through 3 asked students to respond to a set of statements that were matched to their original pre-session survey (Appendix E). Five-point Likert scale statements were ranked from strongly disagree to strongly agree. Statement areas included perceived speaker personality traits, teaching presentation in terms of content and effectiveness, technology assessment, session objectives, questions that relate to student learning objectives and open-ended questions about the part of the session that they liked most and least, the one word they felt described the session, the most important thing they learned in the session, and their opinion of the benefit of the experience. Demographic information and their web cam or videoconference background/experience was requested at the end of the post-survey 
(Appendix F). Students were also given the opportunity to share any comments they had about the experience.

There were two apparel industry professional surveys. The first survey, the Industry Professional Pre-Survey (Appendix G) was a 12-item online survey that asked about the industry professional's number of years in the apparel industry and the number of years at their present position. The survey also asked the industry professional's educational attainment, videoconference experience, and if they had ever been a guest speaker or worked with students. The survey asked if they needed a researcher-supplied web cam The survey also gave the industry professional an opportunity to list any questions they had and asked for factors that hindered them from or encouraged them to participation in a videoconference session.

The second industry professional survey was the Industry Professional Post-Survey (Appendix H). This 15-item online survey contained Likert scale statements and open-ended questions. Professionals were asked about the objectives they felt were met during the session. They were asked to rate the effectiveness of the technology, their assessment of their teaching presentation in terms of content and effectiveness, and how they felt they were perceived by the students. They were also asked about what they felt was the worst and best part of the session. The survey asked if they would be willing to participate in another videoconferencing session and asked what factors would motivate them and what factors would hinder them in participating in another videoconferencing session. Additionally, they were asked to list the benefits they gained as a result of the session and how they thought the session benefitted the students. In the final survey item, they were asked to share any comments, suggestions, or comments about the videoconferencing session they experienced. 
The researcher kept notes on the experiences which occurred while setting up the partnership between the school and the industry professional in areas such as room set up , participant follow through, etc.

\section{Procedures}

Procedure steps for this study follow. Metrejean et al. (2002) listed strategies that maximize the benefits of guest speakers. In their study, they developed a guest speaker event through a set of sequences. This study followed similar steps. Prior to the guest speaker coming to the school, the instructor gave students a short biography of the speaker's education and career background (sources for speaker background might be a copy of their resume, social networking pages, and news sources). With that information, students were instructed to develop two written questions based on the guest's background (Metrejean et al.). The students or instructor e-mailed student questions to the researcher who sorted the questions into categories and sent the two sets of questions to the guest speaker. The first set of questions were general information questions that the speaker addressed in his opening statement and the second set were questions that students were to individually ask, speaking to the guest speaker (camera to camera). Metrejean et al. did this also to ensure that the speakers addressed issues that were of interest to the students.

The procedure for data collections consisted of the following steps:

1. Instructor participants were identified by the researcher and contacted to inquire of their interest in participating in the study.

2. If they showed interest, an Instructor Consent Form (Appendix I) was sent to the instructor.

3. Once the consent form was completed and faxed or scanned and e-mailed to the researcher, the researcher sent a link to the instructor to complete the online pre- 
session survey (Appendix C). This survey identified the type of guest speaker that they desired.

4. The researcher invited a matched industry professional via the Internet to participate in the study. If they showed interest, they were also sent a consent form (Appendix J).

5. Once the consent form was faxed back to the researcher, the researcher sent a link for the industry professional to complete a Pre-Session Survey (Appendix G).

6. Next, a date and time were confirmed with each partner. A test call with Skype was made between the researcher and the school and/or between the researcher and the apparel industry professional or both. This was to insure that the industry professional and the instructor were familiar with how to connect using Skype and that an outside call could get into the classroom without being blocked on the school's website/network.

7. Instructors introduced the activity to the classroom by providing a background on the industry partner. Students were asked to generate two questions of their choosing, to gain information about the industry professional.

8. Researcher accumulated questions that were sent by the instructor or from the students to the researcher directly, who then synthesized and categorized the questions. The questions were sent to the industry professional with the instruction to answer selected questions as a part of their opening statement and to hold the balance of the questions which was asked by individual students. The questions that were to be asked by the students were brought to the school on the day of the videoconference session to be given to the students who asked the guest speaker her/his question.

9. On event day, the researcher was present in the classroom. The classroom's computer had a built-in web cam or a web cam installed before the session. The researcher and industry partner performed a test call within 30 minutes of the session time to make sure that the Skype connection could be made. The live image of the industry professional was projected by a classroom projection system onto a large screen and the school classroom image appeared on the screen of the industry professional's computer screen. Instructors were encouraged to have their school's help desk available in case of unexpected technical issues.

10. Immediately prior to the videoconferencing session, the researcher distributed the Student Pre-Session Surveys. A Student Consent Form (Appendix K) was either printed on the back of the pre-survey or distributed as a single sheet. Students were asked to read the consent form and to ask any questions they had before beginning the survey. The Student Pre-Session Surveys contained a two-part ticket with numbers they wrote on their pre- and post-surveys in order to facilitate 
pre- and posttest response matching. The pre-surveys were collected by the instructor prior to the videoconferencing session. The students pulled off the ticket before turning in the pre-survey.

11. The room was set up with the school's computer screen on a wall with a chair in front of the web camera. The industry professional opened with her talk by answering the questions sent to her by the researcher. The industry professional was prompted by the researcher to say when she was ready for student questions. Students made their way up to ask their questions while sitting in front of the camera. Meanwhile, the other the students were viewing the guest speaker on the projection screen.

12. After the videoconferencing event, students completed the second survey (Student Post-Session Survey; Appendix F) after writing their ticket number on the front page of the second survey. When the survey was completed and submitted, the student gave one part of his ticket into a bowl for a drawing. This drawing/contest was an incentive for students to complete the survey.

13. The instructor pulled two tickets and called out the number. Those two student winners were each given an envelope containing a five dollar bill.

14. The researcher collected all materials and the session was completed.

15. After the session, a link was sent to the apparel industry professional to complete the online Industry Professional Post-Survey (Appendix H).

\section{Data ANalysis}

This study incorporated a mixed method analysis. Because of the instructor $(N=3)$

and apparel industry professional $(N=3)$ small sample sizes, the responses from these sample participants were analyzed qualitatively and with descriptive statistics. Student responses were analyzed using qualitative and quantitative methods.

For student responses to Likert style questions, frequencies and percentages were tabulated. Chi-square test statistics were computed to determine whether student responses in the different areas researched differed significantly. Paired $t$ tests were conducted on pre- and post-student surveys (Appendix F) that measured expectations before the session and whether 
those expectations were met after the session. The data was tested for the best choice of analyses (parametric vs. non-parametric tests). Parametric tests allowed for deeper testing using post hoc analysis procedures. For the study's open-ended questions, frequencies were computed and data was sorted and categorized to discover trends or themes. A one-way analysis of variance (ANOVA) was conducted to test for differences among responses from the three school groups.

The main focus of this study were the student perceptions of the videoconferencing experience for which there were three groups, one group from each school. Descriptive statistics were conducted for student demographic and profile characteristics; quantitative statistics were conducted on associations between variables.

A Student Pre-Survey (Appendix E) assessed student expectations before the videoconferencing session and a section of the Student Post-Survey (Appendix F) assessed whether or not those original expectations were met after the session.

Students chose levels of agreement based on a 5-point Likert scale for the following areas: expectations, perceived guest speaker personality traits, teaching content and effectiveness, technology, session objectives, and overall perceptions. Descriptive statistics in the form of frequencies and percentages of responses were calculated and compared among and between the three student groups (who represent the three schools).

Qualitative statistics were conducted on the open-ended survey questions. The data was collected, coded, and categorized into meaningful groups, with any emerging patterns and themes identified and discussed. These statistics were conducted using the Word processing software, Microsoft Word. Using Microsoft Word can be equivalent to using 
dedicated Qualitative Data Analysis Software for basic qualitative analysis (La Pelle, 2004). Qualitative responses were also compared across and between the three different groups.

Data from the investigator's notes on the experience of setting up the videoconference sessions was also organized and categorized using qualitative techniques to discover any patterns and themes. 


\section{CHAPTER 4}

\section{RESULTS AND FINDINGS}

This chapter presents results and findings from data gathered through student, instructor, and apparel industry professional pre- and post-session surveys (Appendices G and H). Three sets of students were used, each set from a different school identified as school A $(N=21)$, school B $(N=22)$, and school C $(N=27)$ for a total of 70 students. Each group consisted of one guest speaker (industry professional), one instructor, and the instructor's students. Findings will be discussed using individual group sets and the collective three group set. The order of presentation will be sample characteristics, research questions for students, instructors, and apparel industry professionals.

The purpose of this study was to explore the efficacy, benefits and student perceptions of using Internet videoconferencing and a web camera to connect college and university fashion students with apparel industry professionals.

There were five research questions:

1. What are students', instructors', and apparel industry professionals' expectations before participating in an Internet videoconferencing session?

2. What are students' perceptions of their interaction with apparel industry professionals who visited the classroom via Internet videoconferencing?

2.1 Were student expectations met after the videoconferencing session?

2.2 How do the students rate the fashion industry professional's perceived personality traits? 
2.3 What are the students' perception of the fashion industry professional's effectiveness and content knowledge?

2.4 How did technology impact the experience for the students?

2.5 What was the students' overall perception of the experience?

3. What are fashion instructors' perceptions of the Internet videoconferencing experience between their students and apparel industry professionals?

3.1 Were instructor's expectations met?

3.2 According to the instructors, what session objectives were met?

3.3 How did instructors rate the technology of the session?

3.4 How did instructors rate student benefits of the session?

3.4 How did instructors rate the feasibility of the Internet session?

3.5 What was the instructors' overall perception of the experience?

4. What are apparel industry professionals' perceptions of interacting with fashion students via Internet videoconferencing?

4.1 How did apparel industry professionals feel that they benefited the students as a result of the videoconference session?

4.2 What was the apparel industry professionals' overall perception of the experience?

4.3 What factors motivate the fashion industry professional to participate in the Internet videoconferencing session?

4.4 What factors hinder the fashion industry professional in engaging in the Internet videoconferencing interaction with the students?

5. What are hindrances to setting up Internet videoconferencing guest speaking sessions in the college or university classroom? 


\section{SCHOOL INFORMATION}

Students from three schools were used in this study. The schools will be identified respectively as School A, School B, and School C. School A is a public university in a suburban city in the western United States with a student population of over 36,000 students. School B is a public university in a different suburban city in the western United States with a student population of over 20,000 students, and school C is a public 2-year community college in another suburban city in the western United States with a student population of over 18, 000 students (Table 1).

Table 1. School Information

\begin{tabular}{cllc}
\hline School & \multicolumn{1}{c}{ Type of Institution } & \multicolumn{1}{c}{ Location } & Student Population \\
\hline A & Public university & $\begin{array}{l}\text { Suburban U.S. west } \\
\text { coast city }\end{array}$ & Over 36,000 \\
B & Public university & $\begin{array}{l}\text { Suburban U.S. west } \\
\text { coast city }\end{array}$ & Over 20,000 \\
C & Two-year community college & $\begin{array}{l}\text { Suburban U.S. west } \\
\text { coast city }\end{array}$ & Over 18,000 \\
\hline
\end{tabular}

\section{Student Participants}

The sample population (which includes three sets) of students included at total of 70 participants. Frequency distributions were used to define the sample for each student group Collectively, of those responding (all three student groups), $N=68 ; 63(93 \%)$ were female, 5 (7.1\%) were male. Fourteen (20\%) were Caucasian, 10 (14.3\%) were African American, 23 (32.9\%) were Hispanic, $10(14.3 \%)$ were Asian, $1(1.4 \%)$ was Pacific Islander, $1(1.4 \%)$ was a Native American, and $9(12.9 \%)$ identified themselves as other. Most $(72 \%)$ of the students 
were in the age range from 18-25 years old, $12(17.1 \%)$ were between 26 and 35 years of age, $3(4.3 \%)$ were between 36 and 50 , and $1(1.4 \%)$ was over 50 . When asked the highest level of education completed, $1(1.4 \%)$ listed less than high school, $38(54.3 \%)$ listed high school or GED, $18(25.7 \%)$ had attained an AA degree, 4 (5.7\%) had attained a bachelor's degree, and $6(8.6 \%)$ listed other. Thirty (45.4\%) students listed fashion merchandising as their major, 14 (21.2\%) listed fashion design, while 22 (33.3\%) listed other majors (Table 2).

Regarding student experience with prior video communication, most (55.7\%) had never been involved in a videoconference, $10(14.3 \%)$ were involved once, $8(11.4 \%)$ had been involved twice, and $10(14.3 \%)$ had been involved with a videoconference three or more times. Most students (72.9\%) reported having used a web cam while 15 (21.4\%) had not. Half the students reported that they had used Skype previously, while the other half had not (Table 3, p. 53).

\section{INSTRUCTOR PARTICIPANTS}

Two of the instructors were full- time professors and one was a full-time lecturer at the professor level. Two instructors had attained a master's degree and one had obtained a doctorate. All three instructors had been teaching fashion courses for 15 or more years (Table 4, p. 53).

In the past 5 years, two of the instructors had guest speakers come to their classrooms between 6 and 10 times, one had guest speakers come 1 to 5 times, and for all the instructors, the guest speakers had been face to face meetings with the guest speaking physically coming to the classroom (Table 5, p. 53). 
Table 2. Student Demographics

\begin{tabular}{|c|c|c|c|c|}
\hline & School A & School B & School C & Total \\
\hline \multicolumn{5}{|l|}{ Gender } \\
\hline Male & $1(5 \%)$ & $1(5 \%)$ & $3(12 \%)$ & $5(7 \%)$ \\
\hline Female & $19(5 \%)$ & $21(95 \%)$ & $23(88 \%)$ & $63(93 \%)$ \\
\hline Total & $20(100 \%)$ & $22(100 \%)$ & $26(100 \%)$ & $68(100 \%)$ \\
\hline \multicolumn{5}{|l|}{ Ethnicity } \\
\hline Caucasian & $31(15 \%)$ & $6(27 \%)$ & $4(15 \%)$ & $13(19 \%)$ \\
\hline African American & $3(15 \%)$ & $1(5 \%)$ & $6(23 \%)$ & $10(15 \%)$ \\
\hline Hispanic & $7(35 \%)$ & $7(32 \%)$ & $9(35 \%)$ & $23(34 \%)$ \\
\hline Asian & $1(5 \%)$ & $4(18 \%)$ & $5(19 \%)$ & $10(15 \%)$ \\
\hline Pacific Islander & 0 & 0 & $1(4 \%)$ & $1(1 \%)$ \\
\hline Native American & $1(5 \%)$ & 0 & $1(4 \%)$ & $2(3 \%)$ \\
\hline Other & $5(25 \%)$ & $4(18 \%)$ & 0 & $9(13 \%)$ \\
\hline Total & $20(100 \%)$ & $22(100 \%)$ & $26(100 \%)$ & $68(100 \%)$ \\
\hline \multicolumn{5}{|l|}{ Age } \\
\hline $18-25$ & $19(90 \%)$ & $14(64 \%)$ & $18(75 \%)$ & $51(76 \%)$ \\
\hline $26-335$ & $1(4.5 \%)$ & $7(32 \%)$ & $4(17 \%)$ & $12(18 \%)$ \\
\hline $36-50$ & $1(4.5 \%)$ & $1(5 \%)$ & $2(8 \%)$ & $4(5 \%)$ \\
\hline Over 50 & 0 & 0 & 0 & 0 \\
\hline Total & $21(100 \%)$ & $22(100 \%)$ & $24(100 \%)$ & $67(100 \%)$ \\
\hline \multicolumn{5}{|l|}{ Education } \\
\hline Less than high school & 0 & 0 & $1(4 \%)$ & $1(1 \%)$ \\
\hline High school or GED & $13(62 \%)$ & $9(41 \%)$ & $16(67 \%)$ & $38(58 \%)$ \\
\hline Associate's degree & $6(29 \%)$ & $10(45 \%)$ & $2(8 \%)$ & $18(27 \%)$ \\
\hline Bachelor's degree & $2(9 \%)$ & 0 & $4(17 \%)$ & $6(9 \%)$ \\
\hline Other & 0 & $3(14 \%)$ & $1(4 \%)$ & $4(6 \%)$ \\
\hline Total & $21(100 \%)$ & $22(100 \%)$ & $24(100 \%)$ & $67(100 \%)$ \\
\hline \multicolumn{5}{|l|}{ Major } \\
\hline Fashion design & $4(19 \%)$ & $3(14 \%)$ & $7(29 \%)$ & $14(21.2 \%)$ \\
\hline Fashion merchandising & $7(33 \%)$ & $17(81 \%)$ & $6(25 \%)$ & $30(45.4 \%)$ \\
\hline Other & $10(48 \%)$ & $1(5 \%)$ & $11(52 \%)$ & $22(33.3 \%)$ \\
\hline Total & $21(100 \%)$ & $21(100 \%)$ & $24(100 \%)$ & $66(100 \%)$ \\
\hline
\end{tabular}


Table 3. Frequencies for Student Technology Experiences

\begin{tabular}{lcccc}
\hline & School A & School B & School C & Total \\
\hline Video participation & & & & \\
Never & $15(71 \%)$ & $10(45 \%)$ & $14(58 \%)$ & $39(54 \%)$ \\
1 time & $1(5 \%)$ & $5(23 \%)$ & $4(17 \%)$ & $10(15 \%)$ \\
2 times & $2(9 \%)$ & $4(18 \%)$ & $2(8 \%)$ & $8(12 \%)$ \\
3 or more times & $3(14 \%)$ & $3(14 \%)$ & $4(17 \%)$ & $10(15 \%)$ \\
Total & $21(100 \%)$ & $22(100 \%)$ & $24(100 \%)$ & $67(100 \%)$ \\
Previous use of a web cam & & & & \\
Yes & $17(81 \%)$ & $17(77 \%)$ & $17(74 \%)$ & $51(77 \%)$ \\
No & $4(19 \%)$ & $5(23 \%)$ & $6(26 \%)$ & $15(23 \%)$ \\
Total & $21(100 \%)$ & $22(100 \%)$ & $23(100 \%)$ & $66(100 \%)$ \\
Previous use of Skype & & & & \\
Yes & $9(43 \%)$ & $15(68 \%)$ & $11(48 \%)$ & $35(53 \%)$ \\
No & $12(57 \%)$ & $7(32 \%)$ & $12(52 \%)$ & $31(47 \%)$ \\
Total & $21(100 \%)$ & $22(100 \%)$ & $23(100 \%)$ & $66(100 \%)$ \\
\hline
\end{tabular}

Table 4. Instructor Demographics

\begin{tabular}{cllc}
\hline Instructor & \multicolumn{1}{c}{ Title } & $\begin{array}{c}\text { Highest Education } \\
\text { Accomplishment }\end{array}$ & How Long Teaching \\
\hline A & $\begin{array}{l}\text { Full-time lecturer at Assistant } \\
\text { Professor level }\end{array}$ & Master's degree & 15 years and over \\
B & Full-time Professor & Doctorate & 15 years and over \\
C & Full time Professor & Master's degree & 15 years and over \\
\hline
\end{tabular}

Table 5. Instructor Experiences with Guest Speaker

\begin{tabular}{ccc}
\hline & How many guest speakers in class in past & \\
Instructor & 5 years? & Were all face to face speakers? \\
\hline A & $6-10$ & Yes \\
B & $1-5$ & Yes \\
C & $6-10$ & Yes \\
\hline
\end{tabular}


Two of the instructors had taught a course over the Internet, while one had not. None of the instructors had used Skype for personal or teaching purposes (Table 6).

Table 6. Instructor Internet Experiences

\begin{tabular}{ccc}
\hline Instructor & Videoconferencing Experience & Used Skype for Videoconferencing \\
\hline A & Yes & No \\
$B$ & Yes & No \\
C & No & No \\
\hline
\end{tabular}

\section{Industry Professional Participants}

The three industry professionals represented the positions of Apparel Designer, Sr.

Vice President of Merchandising, and Textile Designer. All had attained an educational level of bachelor's degree. The distance between where they were and the school they spoke to varied between 19 and 987 miles (Table 7).

Table 7. Speaker Title, Education, and Distance

\begin{tabular}{lllc}
\hline $\begin{array}{c}\text { Industry } \\
\text { Professional }\end{array}$ & \multicolumn{1}{c}{ Title } & Education & $\begin{array}{c}\text { Approximate Distance } \\
\text { from Speaker Location to } \\
\text { Classroom }\end{array}$ \\
\hline A & Apparel Designer & B.A. Fashion Design & 19 miles \\
B & $\begin{array}{l}\text { Sr. Vice President of } \\
\text { Merchandising }\end{array}$ & B.S. Marketing & 987 miles \\
C & Textile Designer & B.A. Fine Arts & 368 miles \\
\hline
\end{tabular}


Industry professionals had various experiences of being a guest speaker and various experiences with Skype. Two industry professionals had been a guest speaker, one had not. Two of the industry professionals had used Skype and one had not (Table 8).

\section{Table 8. Guest Speaker and Skype Experience}

\begin{tabular}{ccc}
\hline Industry Professional & Pervious Guest Speaker Experience & Previous Skype Use \\
\hline A & Yes & No \\
B & No & Yes \\
C & Yes & Yes \\
\hline
\end{tabular}

\section{ReSEARCh Questions Results}

Research Question One: What are students', instructors', and apparel industry professionals' expectations before participating in an Internet videoconferencing session?

Frequencies and percentages of student expectation responses before the session were analyzed by school as well as the total sample (Table 9). Most (54\%) of the students across all groups agreed or strongly agreed that they expected to learn about real world relationships. Most (57\%) agreed or strongly agreed that they would find the guest speaker to be engaging and interesting and only $40 \%$ agreed or strongly agreed that they would find that the guest speaker promoted his/her company. A chi-square analysis was conducted and no differences in answers were found across or between the schools.

\section{Instructor Expectations}

The instructor from school A strongly agreed that she believed the students would learn about real world relationships and that the guest speaker would be engaging and 
interesting. The instructor was undecided if she believed that the guest speaker would promote his firm/company (Table 10).

The instructor from school B strongly agreed that she believed that the guest speaker would promote his company/firm while only agreeing that she believed that the guest speaker would cause the students to learn about real world relationships and be interesting and engaging (Table 11).

Table 9. Students' Pre-Expectations Ratings

\begin{tabular}{|c|c|c|c|c|c|c|}
\hline & & School A & School B & School C & Total & $\chi^{2}(d f)$ \\
\hline \multicolumn{7}{|c|}{ Will learn about real world relationships } \\
\hline & Disagree & $1(5.0 \%)$ & $0(0.0 \%)$ & $0(0.0 \%)$ & $1(1.5 \%)$ & $5.91(6)$ \\
\hline & Undecided & $4(20.0 \%)$ & $2(9.5 \%)$ & $6(23.1 \%)$ & $12(17.9 \%)$ & \\
\hline & Agree & $10(50.0 \%)$ & $16(76.2 \%)$ & $14(53.8 \%)$ & $40(59.7 \%)$ & \\
\hline & Strongly agree & $5(2.0 \%)$ & $3(14.3 \%)$ & $6(23.1 \%)$ & $14(20.9 \%)$ & \\
\hline Total & & $20(100 \%)$ & $21(100 \%)$ & $26(100 \%)$ & $67(100 \%)$ & \\
\hline \multicolumn{7}{|c|}{ Guest will be engaging and interesting } \\
\hline & Disagree & $1(5.0 \%)$ & $0(0.0 \%)$ & $0(0.0 \%)$ & $1(1.5 \%)$ & $3.78(6)$ \\
\hline & Undecided & $4(20.0 \%)$ & $2(9.5 \%)$ & $3(11.5 \%)$ & $9(13.4 \%)$ & \\
\hline & Agree & $7(35.0 \%)$ & $10(47.6 \%)$ & $12(46.2 \%)$ & $29(43.3 \%)$ & \\
\hline & Strongly agree & $8(40.0 \%)$ & $9(42.9 \%)$ & $11(42.3 \%)$ & $28(41.8 \%)$ & \\
\hline Total & & $20(100 \%)$ & $21(100 \%)$ & $26(100 \%)$ & $67(100 \%)$ & \\
\hline \multicolumn{7}{|c|}{ Guest will promote firm } \\
\hline & Strongly disagree & $1(4.8 \%)$ & $0(0.0 \%)$ & $0(0.0 \%)$ & $1(1.5 \%)$ & $7.78(8)$ \\
\hline & Disagree & $0(0.0 \%)$ & $0(0.0 \%)$ & $1(3.8 \%)$ & $1(1.5 \%)$ & \\
\hline & Undecided & $5(23.8 \%)$ & $8(38.1 \%)$ & $13(50.0 \%)$ & $26(38.2 \%)$ & \\
\hline & Agree & $8(38.1 \%)$ & $7(33.3 \%)$ & $8(30.8 \%)$ & $23(33.8 \%)$ & \\
\hline & Strongly agree & $7(33.3 \%)$ & $6(28.6 \%)$ & $4(15.4 \%)$ & $17(25.0 \%)$ & \\
\hline Total & & $21(100 \%)$ & $21(100 \%)$ & $26(100 \%)$ & $68(100 \%)$ & \\
\hline
\end{tabular}

Note. None of the percentages differed by guest speaker. 
Table 10. Instructor A Pre-Survey Expectations

\begin{tabular}{llccc}
\hline \multicolumn{1}{c}{ School A } & $\begin{array}{l}\text { Strongly } \\
\text { Disagree }\end{array}$ & Disagree & Undecided & $\begin{array}{c}\text { Agree } \\
\text { Agree }\end{array}$ \\
\hline $\begin{array}{l}\text { 1. I believe the students will learn } \\
\text { about real world relationships. }\end{array}$ & & $\mathrm{X}$ \\
$\begin{array}{l}\text { 2. I believe that the guest speaker } \\
\text { will be engaging and interesting. }\end{array}$ & & $\mathrm{X}$ \\
$\begin{array}{l}\text { 3. I believe the guest speaker will } \\
\text { promote his company/firm. }\end{array}$ & $\mathrm{X}$ & \\
\hline
\end{tabular}

\section{Table 11. Instructor B Pre-Survey Expectations}

\begin{tabular}{|c|c|c|c|c|c|}
\hline School B & $\begin{array}{l}\text { Strongly } \\
\text { Disagree }\end{array}$ & Disagree & Undecided & Agree & $\begin{array}{l}\text { Strongly } \\
\text { Agree }\end{array}$ \\
\hline $\begin{array}{l}\text { 1. I believe the students will learn } \\
\text { about real world relationships. }\end{array}$ & & & & $X$ & \\
\hline $\begin{array}{l}\text { 2. I believe that the guest speaker } \\
\text { will be engaging and interesting. }\end{array}$ & & & & $X$ & \\
\hline $\begin{array}{l}\text { 3. I believe the guest speaker will } \\
\text { promote his company/firm. }\end{array}$ & & & & & $\mathrm{X}$ \\
\hline
\end{tabular}

The instructor from school $\mathrm{C}$ agreed that he believed that the students will learn about real world relationships and that the guest speaker would be engaging and interesting. He was undecided about whether he believed that the guest speaker would promote his company/firm (Table 12).

Collective instructor expectations from all three instructor pre-surveys (Appendix C) included the following: two instructors agreed that they believed the students will learn about real world relationships. One instructor strongly agreed. Two instructors agreed that they believed that the guest speaker will be engaging and interesting, one instructor strongly 
agreed. Two instructors were undecided if they believed the guest speaker would promote his company/firm, one strongly agreed that they believed that the guest speaker would promote his company/firm (Table 13).

\section{Table 12. Instructor C Pre-Survey Expectations}

\begin{tabular}{llccc}
\hline \multicolumn{1}{c}{ School C } & $\begin{array}{l}\text { Strongly } \\
\text { Disagree }\end{array}$ & Disagree & Undecided & $\begin{array}{c}\text { Agree } \\
\begin{array}{c}\text { Strongly } \\
\text { Agree }\end{array}\end{array}$ \\
\hline $\begin{array}{l}\text { 1. I believe the students will learn } \\
\text { about real world relationships. }\end{array}$ & $\mathrm{X}$ \\
$\begin{array}{l}\text { 2. I believe that the guest speaker } \\
\text { will be engaging and interesting. }\end{array}$ & $\mathrm{X}$ \\
$\begin{array}{l}\text { 3. I believe the guest speaker will } \\
\text { promote his company/firm. }\end{array}$ & $\mathrm{X}$ & \\
\hline
\end{tabular}

Table 13. Instructor A, B, and C Pre-Survey Expectations

\begin{tabular}{|c|c|c|c|c|c|}
\hline $\begin{array}{l}\text { Collective Instructor } \\
\text { Expectations }\end{array}$ & $\begin{array}{l}\text { Strongly } \\
\text { Disagree }\end{array}$ & Disagree & Undecided & Agree & $\begin{array}{l}\text { Strongly } \\
\text { Agree }\end{array}$ \\
\hline $\begin{array}{l}\text { 1. I believe the students will learn } \\
\text { about real world relationships. }\end{array}$ & & & & 2 & 1 \\
\hline $\begin{array}{l}\text { 2. I believe that the guest speaker } \\
\text { will be engaging and interesting. }\end{array}$ & & & & 2 & 1 \\
\hline $\begin{array}{l}\text { 3. I believe the guest speaker will } \\
\text { promote his company/firm. }\end{array}$ & & & 2 & & 1 \\
\hline
\end{tabular}

\section{Industry Professional Expectations}

Two of the industry professionals strongly agreed that they would help students learn about the real world, while one industry professional simply agreed. Two of the industry professionals disagreed that they would promote their company, while one professional 
strongly disagreed. Two of the industry professionals were undecided that they would find potential employees, while one professional disagreed (Table 14).

Table 14. Collective Industry Professional Expectations

\begin{tabular}{lccccc}
\hline & $\begin{array}{c}\text { Strongly } \\
\text { Disagree }\end{array}$ & Disagree & Undecided & $\begin{array}{c}\text { Agree } \\
\text { Strongly } \\
\text { Agree }\end{array}$ \\
\hline $\begin{array}{l}\text { 1. I would help the students learn } \\
\text { about the real world. }\end{array}$ & & & 1 & 2 \\
2. I would promote my company. & 1 & 2 & & \\
$\begin{array}{l}\text { 3. I would find potential future } \\
\text { employees. }\end{array}$ & & 1 & 2 & \\
\hline
\end{tabular}

Research Question Two: What are students' perceptions of their interaction with apparel industry professionals who visited the classroom via Internet videoconferencing?

Sub question 2.1 asks: Were student expectations met after the videoconferencing session?

Frequencies and percentages of whether the expectations of students were met after the session are presented by group as well as for the total sample in Table 15. Most all of the students across all groups agreed or strongly agreed that they (a) learned about real world relationships, (b) found the guest speaker to be engaging and interesting, and (c) found that the guest speaker promoted her company; however, there were more undecided answers for the promotion question. There were no differences in answers across the groups.

To further address whether student expectations were met, paired $t$ tests were computed between the ratings before and after the sessions for the total sample. Table 16 (p. 61) presents the results of the paired $t$ tests. As can be seen in Table 16, the students' expectations for learning about the real world and whether the speaker would be interesting 
were exceeded. The ratings for learning about real world relationships were significantly

higher after the session than the expectations ratings before the session. The same held for the ratings of how interesting the speaker would be. For whether the speaker would promote her company, Table 16 (p. 61) shows that the post sessions ratings were slightly lower, but this difference was not significant.

Table 15. Student Post-Expectations Ratings

\begin{tabular}{|c|c|c|c|c|c|c|}
\hline & & School A & School B & School C & Total & $\chi^{2}(d f)$ \\
\hline \multicolumn{7}{|c|}{ Learned about real world relationships } \\
\hline & Disagree & 0 & 0 & 1 & 1 & $3.92(6)$ \\
\hline & Undecided & 0 & 0 & $1(3.7 \%)$ & $1(1.4 \%)$ & \\
\hline & Agree & $13(61.9 \%)$ & $11(50 \%)$ & $14(51.9 \%)$ & $38(54.3 \%)$ & \\
\hline & Strongly agree & $8(38.1 \%)$ & $11(50 \%)$ & $11(40.7 \%)$ & $30(42.9 \%)$ & \\
\hline Total & & $21(100 \%)$ & $22(100 \%)$ & $27(100 \%)$ & $70(100 \%)$ & \\
\hline \multicolumn{7}{|c|}{ Guest was engaging and interesting } \\
\hline & Undecided & 0 & $2(9.1 \%)$ & 0 & $2(2.9 \%)$ & $5.86(4)$ \\
\hline & Agree & $3(14.3 \%)$ & $3(13.6 \%)$ & $7(25.9 \%)$ & $13(18.6 \%)$ & \\
\hline & Strongly agree & $18(85.7 \%)$ & $17(77.3 \%)$ & $20(71.4 \%)$ & $55(78.6 \%)$ & \\
\hline Total & & $21(100 \%)$ & $22(100 \%)$ & $27(100 \%)$ & $70(100 \%)$ & \\
\hline \multicolumn{7}{|c|}{ Guest promoted firm } \\
\hline & Strongly disagree & 0 & $2(9.1 \%)$ & $2(7.5 \%)$ & $4(5.7 \%)$ & $10.60(8)$ \\
\hline & Disagree & $2(9.5 \%)$ & $4(18.2 \%)$ & $4(14.8 \%)$ & $10(14.3 \%)$ & \\
\hline & Undecided & $1(4.8 \%)$ & $5(22.7 \%)$ & $5(18.5 \%)$ & $11(15.7 \%)$ & \\
\hline & Agree & $9(42.9 \%)$ & $2(9.1 \%)$ & $9(33.3 \%)$ & $20(28 \%)$ & \\
\hline & Strongly agree & $9(42.9 \%)$ & $9(40.9 \%)$ & $7(25.9 \%)$ & $25(35.7 \%)$ & \\
\hline Total & & $21(100 \%)$ & $22(100 \%)$ & $27(100 \%)$ & $70(1005 \%)$ & \\
\hline
\end{tabular}

Note. None of the percentages differed by guest speaker.

Nonparametric Wilcoxon tests were computed for the same pre/post comparisons since the items used were Likert type items and are thus measured on an ordinal scale. The same levels of significance were found using the Wilcoxon tests, such that the first two 
comparisons were significant at $p<.001$ and the third was not significant. Thus, only the parametric paired $t$ test results are shown.

Table 16. Paired $t$ Tests Comparing Student Pre- and Post-Expectations for All Groups

\begin{tabular}{lcccc}
\hline & Pre & Post & Difference & \\
& $M(S D)$ & $M(S D)$ & $M(S D)$ & $t(d f)$ \\
\hline Learn & $4.00(0.67)$ & $4.40(0.60)$ & $0.40(0.72)$ & $4.59(66)^{*}$ \\
Interest & $4.24(0.80)$ & $4.76(0.50)$ & $0.52(0.82)$ & $5.20(66)^{*}$ \\
Promote & $3.79(0.89)$ & $3.72(1.26)$ & $-0.07(1.25)$ & $0.48(67)$ \\
\hline
\end{tabular}

Note. $N=67$ for Learn and Interest and $N=68$ for Promote.

${ }^{*} p<.001$.

Three Likert scale questions were asked of students before the videoconferencing session. Students were asked similar questions after the session in order to measure if their expectations were met. There was there a difference in the pre and post perception of the videoconference sessions. Difference scores were computed by subtracting the pre-session ratings of Learn, Interest, and Promote from the post-session ratings of the same items such that positive differences indicate an increase in ratings from before to after the session, and negative differences indicate a decrease in ratings. Table 17 presents the mean difference scores for each group. In general, all ratings were higher after the sessions than before, indicating that the sessions exceeded the students' expectations except for the "promote" ratings for Groups B and C, which decreased.

The next step was to compute one-way ANOVAs to compare the difference scores across the groups. None of the ANOVAs indicated any significant differences in ratings across groups. Since the item ratings were ordinal in nature, the nonparametric 
Kruskal-Wallis test was also computed for each measure. The Kruskal-Wallis tests provided the same nonsignificant results; thus, only the ANOVA results are presented. In sum, there were no differences in the post minus pre expectations ratings by school or by guest speaker.

Table 17. ANOVAs Comparing the Difference in Student Pre- and Post-Expectations

\begin{tabular}{lcccc}
\hline & School A & School B & School C & \\
& $M(S D)$ & $M(S D)$ & $M(S D)$ & $F\left(d f_{\mathrm{N}}, d f_{\mathrm{D}}\right)$ \\
\hline Learn & $0.45(0.89)$ & $0.48(0.51)$ & $0.31(0.74)$ & $0.37(2,64)$ \\
Interest & $0.80(1.06)$ & $0.33(0.73)$ & $0.46(0.65)$ & $0.17(2,64)$ \\
Promote & $0.24(1.34)$ & $-0.43(1.29)$ & $-0.04(1.11)$ & $0.22(1,65)$ \\
\hline
\end{tabular}

Note. The means did not differ by guest speaker. For guest $\mathrm{A}, N=207$ for Learn and Interest, $N=21$ for Promote; for guest $\mathrm{B}, N=21$; for guest C, $N=26$.

Sub question 2.2 asks: How do the students rate the fashion industry professional's perceived personality traits?

Table 18 presents the ratings of the guest speakers' personalities separately by group as well as for the total sample. In general, all speakers were given very good perceived personality ratings such that almost all perceived personality traits were rated overwhelmingly with agree or strongly agree. Significant differences were found for "The guest speaker was creative and imaginative" and "The guest speaker was energetic, positive, and enthusiastic." For creativity and imagination, the differences mostly occurred between the agree and strongly agree ratings; however, guest speaker B had a greater frequency of undecideds and disagrees. For energy, again, most of the differences occurred between agree and strongly agree, such that guest speaker A received $90.5 \%$ strongly agree, guest speaker B received $68.2 \%$ strongly agree and guest speaker $\mathrm{C}$ received $44.4 \%$ strongly agree. 
Table 18. Student Personality Ratings of Industry Professional

\begin{tabular}{|c|c|c|c|c|c|c|}
\hline & & $\begin{array}{c}\text { School A } \\
\text { Guest A }\end{array}$ & $\begin{array}{c}\text { School B } \\
\text { Guest B }\end{array}$ & $\begin{array}{l}\text { School C } \\
\text { Guest C }\end{array}$ & Total & $\chi^{2}(d f)$ \\
\hline \multicolumn{7}{|c|}{ The guest speaker was pleasant } \\
\hline & Agree & $2(9.5 \%)$ & $8(36.4 \%)$ & $9(33.3 \%)$ & $19(27.1 \%)$ & \multirow[t]{3}{*}{$4.77(2)$} \\
\hline & Strongly agree & $19(90.5 \%)$ & $14(63.6 \%)$ & $18(66.7 \%)$ & $51(72.9 \%)$ & \\
\hline Total & & $21(100 \%)$ & $22(100 \%)$ & $27(100 \%)$ & $70(100 \%)$ & \\
\hline \multicolumn{7}{|c|}{ The guest speaker was creative and imaginative } \\
\hline & Disagree & 0 & $1(4.5 \%)$ & 0 & $1(1.4 \%)$ & \multirow[t]{5}{*}{$16.82(6)^{*}$} \\
\hline & Undecided & 0 & $4(18.2 \%)$ & $2(7.4 \%)$ & $6(8.6 \%)$ & \\
\hline & Agree & $5(23.8 \%)$ & $7(31.8 \%)$ & $17(36.0 \%)$ & $29(41.4 \%)$ & \\
\hline & Strongly agree & $16(76.2 \%)$ & $10(45.5 \%)$ & $8(16.6 \%)$ & $34(48.6 \%)$ & \\
\hline Total & & $21(100 \%)$ & $22(100 \%)$ & $27(100 \%)$ & $70(100 \%)$ & \\
\hline \multicolumn{7}{|c|}{ The guest speaker was self-disciplined and conscientious } \\
\hline & Disagree & 0 & $0(0.0 \%)$ & $1(3.7 \%)$ & $1(1.4 \%)$ & $6.07(6)$ \\
\hline & Undecided & 0 & $0(0.0 \%)$ & $2(7.4 \%)$ & $2(2.9 \%)$ & \\
\hline & Agree & $5(23.8 \%)$ & $6(27.3 \%)$ & $9(33.3 \%)$ & $20(28.6 \%)$ & \\
\hline & Strongly agree & $16(76.2 \%)$ & $16(72.7 \%)$ & $15(55.6 \%)$ & $47(67.1 \%)$ & \\
\hline Total & & $21(100 \%)$ & $22(100 \%)$ & $27(100 \%)$ & $70(100 \%)$ & \\
\hline \multicolumn{7}{|c|}{ The guest speaker was energetic, positive, and enthusiastic } \\
\hline & Undecided & 0 & $1(4.5 \%)$ & $1(3.7 \%)$ & $2(2.9 \%)$ & $11.64(4)^{* *}$ \\
\hline & Agree & $2(9.5 \%)$ & $6(27.3 \%)$ & $14(51.9 \%)$ & $22(31.4 \%)$ & \\
\hline & Strongly agree & $19(90.5 \%)$ & $15(68.2 \%)$ & $12(44.4 \%)$ & $46(65.7 \%)$ & \\
\hline Total & & $21(100 \%)$ & $22(100 \%)$ & $27(100 \%)$ & $70(100 \%)$ & \\
\hline \multicolumn{7}{|c|}{ The guest speaker was compassionate and friendly } \\
\hline & Agree & $1(4.8 \%)$ & $5(22.87 \%)$ & $4(14.8 \%)$ & $10(14.3 \%)$ & $2.84(2)$ \\
\hline & Strongly agree & $20(95.2 \%)$ & $17(77.3 \%)$ & $23(85.2 \%)$ & $60(85.7 \%)$ & \\
\hline Total & & $21(100 \%)$ & $22(100 \%)$ & $27(100 \%)$ & $70(100 \%)$ & \\
\hline \multicolumn{7}{|c|}{ The guest speaker was calm and relaxed } \\
\hline & Undecided & 0 & 0 & $1(3.7 \%)$ & $1(1.4 \%)$ & $4.23(4)$ \\
\hline & Agree & $2(9.5 \%)$ & $1(4.5 \%)$ & $5(18.5 \%)$ & $8(11.4 \%)$ & \\
\hline & Strongly agree & $19(90.5 \%)$ & $21(95.5 \%)$ & $21(100 \%)$ & $61(87.1 \%)$ & \\
\hline Total & & $21(100 \%)$ & $22(100 \%)$ & $27(100 \%)$ & $70(100 \%)$ & \\
\hline
\end{tabular}




\begin{tabular}{lccccc}
\hline & $\begin{array}{c}\text { School A } \\
\text { Guest A }\end{array}$ & $\begin{array}{c}\text { School B } \\
\text { Guest B }\end{array}$ & $\begin{array}{c}\text { School C } \\
\text { Guest C }\end{array}$ & Total & $\chi^{2}(d f)$ \\
\hline \multicolumn{6}{c}{ The guest speaker was humorous } \\
Disagree & 0 & 0 & $1(3.7 \%)$ & $1(1.4 \%)$ & $9.07(6)$ \\
Undecided & $1(4.8 \%)$ & $4(18.2 \%)$ & $3(11.1 \%)$ & $8(11.46 \%)$ & \\
Agree & $6(28.6 \%)$ & $9(40.9 \%)$ & $15(55.6 \%)$ & $30(42.9 \%)$ & \\
Strongly agree & $14(66.7 \%)$ & $9(40.9 \%)$ & $8(29.6 \%)$ & $31(44.3 \%)$ & \\
Total & $21(100 \%)$ & $22(100 \%)$ & $27(100 \%)$ & $70(100 \%)$ & \\
\hline
\end{tabular}

${ }^{*} p<.01 . \quad * * p<.05$.

Sub question 2.3 asks: What are the students' perception of the fashion industry professional's effectiveness and content knowledge?

Table 19 presents the ratings of the guest speakers' content and effectiveness separately by group and for the total sample. In general, all speakers were given very good effectiveness ratings such that most ratings were in the agree or strongly agree categories. Significant differences were found only for "I would like to have more sessions like this." Surprisingly, $100 \%$ of Group C answered agree or strongly agree, $86.3 \%$ of Group B answered agree or strongly agree, but only $61.9 \%$ of Group A answered agree or strongly agree.

Sub question 2.4 asks: How did technology impact the experience for the students?

Table 20 (p. 69) presents the ratings of technology separately by schools as well as for the total sample of three schools. In general, the quality of the audio had some lower ratings across all sessions. Significant differences across groups were found for the ratings of the video quality and the ratings for whether the technology functioned properly. The video ratings tended to be lower for Group B, and the overall technology ratings were best for Group A and were a little worse for Groups B and C. 
Table 19. Student Content and Effectiveness Ratings for Industry Professional

\begin{tabular}{|c|c|c|c|c|c|c|}
\hline & & $\begin{array}{c}\text { Guest } \\
\text { Speaker A }\end{array}$ & $\begin{array}{c}\text { Guest } \\
\text { Speaker B }\end{array}$ & $\begin{array}{c}\text { Guest } \\
\text { Speaker C }\end{array}$ & Total & $\chi^{2}(d f)$ \\
\hline \multicolumn{7}{|c|}{ The guest speaker dressed professionally } \\
\hline Total & $\begin{array}{l}\text { Disagree } \\
\text { Undecided } \\
\text { Agree } \\
\text { Strongly agree }\end{array}$ & $\begin{array}{c}0 \\
2(9.5 \%) \\
13(61.9 \%) \\
6(28.6 \%) \\
21(100 \%)\end{array}$ & $\begin{array}{c}0 \\
4(18.2 \%) \\
18(36.4 \%) \\
10(45.5 \%) \\
22(100 \%)\end{array}$ & $\begin{array}{c}1(3.7 \%) \\
9(33.3 \%) \\
14(51.9 \%) \\
3(11.1 \%) \\
27(100 \%)\end{array}$ & $\begin{array}{c}1(1.4 \%) \\
15(21.4 \%) \\
35(50.0 \%) \\
19(27.1 \%) \\
70(100 \%)\end{array}$ & $11.60(6)$ \\
\hline \multicolumn{7}{|c|}{ The guest speaker was well prepared } \\
\hline Total & $\begin{array}{l}\text { Disagree } \\
\text { Undecided } \\
\text { Agree } \\
\text { Strongly agree }\end{array}$ & $\begin{array}{c}0 \\
0 \\
6(28.6 \%) \\
15(71.4 \%) \\
21(100 \%)\end{array}$ & $\begin{array}{c}1(4.5 \%) \\
0 \\
6(27.3 \%) \\
15(68.2 \%) \\
22(100 \%)\end{array}$ & $\begin{array}{c}0 \\
3(11.1 \%) \\
7(25.9 \%) \\
17(63.0 \%) \\
27(100 \%)\end{array}$ & $\begin{array}{c}1(1.4 \%) \\
3(4.3 \%) \\
19(27.1 \%) \\
47(65.1 \%) \\
70(100 \%)\end{array}$ & $7.12(6)$ \\
\hline \multicolumn{7}{|c|}{ The guest speaker was organized } \\
\hline Total & $\begin{array}{l}\text { Undecided } \\
\text { Agree } \\
\text { Strongly agree }\end{array}$ & $\begin{array}{c}0 \\
8(38.1 \%) \\
13(61.9 \%) \\
21(100 \%)\end{array}$ & $\begin{array}{c}0(0.0 \%) \\
7(31.8 \%) \\
15(68.2 \%) \\
22(100 \%)\end{array}$ & $\begin{array}{c}1(3.7 \%) \\
12(44.4 \%) \\
14(51.9 \%) \\
27(100 \%)\end{array}$ & $\begin{array}{c}1(1.4 \%) \\
27(38.6 \%) \\
42(60.0 \%) \\
70(100 \%)\end{array}$ & $2.65(4)$ \\
\hline \multicolumn{7}{|c|}{ The guest speaker obviously knew her material } \\
\hline Total & $\begin{array}{l}\text { Undecided } \\
\text { Agree } \\
\text { Strongly agree }\end{array}$ & $\begin{array}{c}0 \\
2(9.5 \%) \\
19(90.5 \%) \\
21(100 \%)\end{array}$ & $\begin{array}{c}0 \\
4(18.2 \%) \\
18(81.8 \%) \\
22(100 \%)\end{array}$ & $\begin{array}{c}1(3.7 \%) \\
5(18.5 \%) \\
21(77.8 \%) \\
27(100 \%)\end{array}$ & $\begin{array}{c}1(1.49 \%) \\
11(15.7 \%) \\
58(82.09 \%) \\
70(100 \%)\end{array}$ & $2.56(4)$ \\
\hline \multicolumn{7}{|c|}{ The guest speaker was intelligent } \\
\hline Total & $\begin{array}{l}\text { Agree } \\
\text { Strongly agree }\end{array}$ & $\begin{array}{l}31(14.3 \%) \\
18(85.7 \%) \\
21(100 \%)\end{array}$ & $\begin{array}{c}7(31.8 \%) \\
15(68.2 \%) \\
22(100 \%)\end{array}$ & $\begin{array}{c}7(15.9 \%) \\
20(74.1 \%) \\
27(100 \%)\end{array}$ & $\begin{array}{l}17(24.3 \%) \\
53(75.7 \%) \\
70(100 \%)\end{array}$ & $1.86(2)$ \\
\hline \multicolumn{7}{|c|}{ The guest speaker was interesting } \\
\hline Total & $\begin{array}{l}\text { Undecided } \\
\text { Agree } \\
\text { Strongly agree }\end{array}$ & $\begin{array}{c}0 \\
2(9.5 \%) \\
19(90.5 \%) \\
21(100 \%)\end{array}$ & $\begin{array}{c}1(4.5 \%) \\
6(27.3 \%) \\
15(68.2 \%) \\
22(100 \%)\end{array}$ & $\begin{array}{c}0 \\
10(37.0 \%) \\
17(63.0 \%) \\
27(100 \%)\end{array}$ & $\begin{array}{c}1(1.4 \%) \\
18(25.7 \%) \\
51(72.9 \%) \\
70(100 \%)\end{array}$ & $7.01(4)$ \\
\hline
\end{tabular}


Table 19 (continued)

\begin{tabular}{|c|c|c|c|c|c|c|}
\hline & & $\begin{array}{c}\text { Guest } \\
\text { Speaker A }\end{array}$ & $\begin{array}{c}\text { Guest } \\
\text { Speaker B }\end{array}$ & $\begin{array}{c}\text { Guest } \\
\text { Speaker C }\end{array}$ & Total & $\chi^{2}(d f)$ \\
\hline \multicolumn{7}{|c|}{ The guest speaker captured and held my attention } \\
\hline & Disagree & 0 & $1(4.5 \%)$ & 0 & $1(2.4 \%)$ & $6.24(6)$ \\
\hline & Undecided & 0 & $1(4.5 \%)$ & $2(4.3 \%)$ & $3(4.3 \%)$ & \\
\hline & Agree & $4(19.0 \%)$ & $6(27.3 \%)$ & $10(37.0 \%)$ & $20(28.6 \%)$ & \\
\hline & Strongly agree & $1781.0 \%)$ & $14(63.6 \%)$ & $15(55.6 \%)$ & $46(65.7 \%)$ & \\
\hline Total & & $21(100 \%)$ & $22(100 \%)$ & $27(100 \%)$ & $70(100 \%)$ & \\
\hline \multicolumn{7}{|c|}{ The presentation was thought-provoking } \\
\hline & Strongly disagree & 0 & 0 & $1(3.7 \%)$ & $1(1.4 \%)$ & $5.97(8)$ \\
\hline & Disagree & 0 & 0 & $1(3.7 \%)$ & $1(1.4 \%)$ & \\
\hline & Undecided & $2(9.5 \%)$ & $6(27.3 \%)$ & $57(18.5 \%)$ & $13(11.4 \%)$ & \\
\hline & Agree & $9(42.9 \%)$ & $6(27.3 \%)$ & $8(29.6 \%)$ & $23(32.9 \%)$ & \\
\hline & Strongly agree & $10(47.6 \%)$ & $10(45.5 \%)$ & $12(44.4 \%)$ & $32(45.7 \%)$ & \\
\hline Total & & $21(100 \%)$ & $22(100 \%)$ & $27(100 \%)$ & $70(100 \%)$ & \\
\hline
\end{tabular}

The guest speaker communicated at a level that I understood

$\begin{array}{ccccc}\text { Disagree } & 0 & 0 & 1(3.7 \%) & 1(1.4 \%) \\ \text { Undecided } & 0 & 0 & 2(7.4 \%) & 2(2.9 \%) \\ \text { Agree } & 4(19.0 \%) & 6(27.3 \%) & 4(14.8 \%) & 14(20.0 \%) \\ \text { Strongly agree } & 17(81.0 \%) & 16(72.7 \%) & 20(74.1 \%) & 53(75.7 \%) \\ \text { Total } & 21(100 \%) & 22(100 \%) & 27(100 \%) & 70(100 \%)\end{array}$

$5.84(6)$

The guest speaker was relaxed

$\begin{array}{cccccc}\text { Undecided } & 1(4.8 \%) & 0 & 0 & 1(1.4 \%) & 2.85(4) \\ \text { Agree } & 3(14.3 \%) & 5(11.7 \%) & 6(22.2 \%) & 14(20.0 \%) & \\ \text { Strongly agree } & 17(81.0 \%) & 17(77.3 \%) & 21(77.8 \%) & 55(78.6 \%) & \\ \text { Total } & 21(100 \%) & 22(100 \%) & 27(100 \%) & 70(100 \%)\end{array}$

The guest speaker effectively communicated his/her subject of expertise

$\begin{array}{ccccc}\text { Undecided } & 0 & 0 & 2(7.4 \%) & 2(2.9 \%) \\ \text { Agree } & 1(4.8 \%) & 4(18.2 \%) & 5(18.5 \%) & 10(14.3 \%) \\ \text { Strongly agree } & 20(95.2 \%) & 18(81.8 \%) & 2(7.4 \%) & 58(82.9 \%) \\ \text { Total } & 21(100 \%) & 22(100 \%) & 27(100 \%) & 70(100 \%)\end{array}$

I would like to see ths guest speaker invited back to speak to another class

Undecided

Agree Total
Strongly agree

$\begin{array}{cccc}0 & 0 & 2(7.4 \%) & 2(2.9 \%) \\ 6(28.6 \%) & 7(31.8 \%) & 8(29.6 \%) & 21(30.0 \%) \\ 15(71.4 \%) & 15(68.2 \%) & 17(63.0 \%) & 47(67.1 \%) \\ 21(100 \%) & 22(100 \%) & 27(100 \%) & 70(100 \%)\end{array}$

$5.73(4)$

$3.36(4)$ 


\begin{tabular}{lccccc}
\hline & $\begin{array}{c}\text { Guest } \\
\text { Speaker A }\end{array}$ & $\begin{array}{c}\text { Guest } \\
\text { Speaker B }\end{array}$ & $\begin{array}{c}\text { Guest } \\
\text { Speaker C }\end{array}$ & Total & $\chi^{2}(d f)$ \\
\hline \multicolumn{7}{c}{ I would like to have more sessions like this } \\
Disagree & $2(9.5 \%)$ & $1(4.5 \%)$ & 0 & $3(4.3 \%)$ & $16.06(6)^{*}$ \\
Undecided & $6(28.6 \%)$ & $2(9.1 \%)$ & 0 & $8(11.4 \%)$ & \\
Agree & $5(23.8)$ & $3(13.6 \%)$ & $10(37.0 \%)$ & $18(25.7 \%)$ & \\
Strongly agree & $8(38.1 \%)$ & $16(72.7 \%)$ & $17(63.0 \%)$ & $41(58.6 \%)$ & \\
Total & $21(100 \%)$ & $22(100 \%)$ & $27(100 \%)$ & $70(100 \%)$ &
\end{tabular}

Total

$\begin{array}{lccccc}\text { Disagree } & 2(9.5 \%) & 1(4.5 \%) & 1(3.7 \%) & 4(5.7 \%) & 4.26(6) \\ \text { Undecided } & 7(33.3 \%) & 5(22.7 \%) & 6(22.2 \%) & 18(25.7 \%) & \\ \text { Agree } & 8(38.1 \%) & 9(40.9 \%) & 8(29.6 \%) & 25(35.7 \%) & \\ \text { Strongly agree } & 4(19.0 \%) & 7(31.8 \%) & 12(44.4 \%) & 23(32.9 \%) & \\ & 21(100 \%) & 22(100 \%) & 27(100 \%) & 70(100 \%) & \end{array}$

This experience was beneficial for me

$\begin{array}{cccccc}\text { Undecided } & 0 & 1(4.5 \%) & 2(7.4 \%) & 3(4.3 \%) & 3.24(4) \\ \text { Agree } & 11(52.4 \%) & 7(31.8 \%) & 10(37.0 \%) & 28(40.0 \%) & \\ \text { Strongly agree } & 10(47.6 \%) & 14(63.6 \%) & 15(55.6 \%) & 39(55.7 \%) & \\ \text { Total } & 21(100 \%) & 22(100 \%) & 27(100 \%) & 70(100 \%) & \end{array}$

Overall, the presentation was a worthwhile, educational experience

$\begin{array}{lccccc}\text { Agree } & 5(29.4 \%) & 5(22,7 \%) & 6(23.1 \%) & 16(24.6 \%) & 0.29(2) \\ \text { Strongly agree } & 12(70.6 \%) & 17(77.3 \%) & 20(76.9 \%) & 49(75.4 \%) & \\ \text { Total } & 17(100 \%) & 22(100 \%) & 26(100 \%) & 65(100 \%) & \end{array}$

The guest speaker was easy to talk to

Total

Undecided

Agree

Strongly agree

Total

\begin{tabular}{ccccc}
\multicolumn{1}{c}{ Undecided } & 0 & 0 & $1(3.7 \%)$ & $1(1.4 \%)$ \\
Agree & $2(9.5 \%)$ & $3(13.6 \%)$ & $9(33.3 \%)$ & $14(20.0 \%)$ \\
\multirow{2}{*}{ Strongly agree } & $19(90.5 \%)$ & $19(86.4 \%)$ & $17(63.0 \%)$ & $55(78.6 \%)$ \\
Total & $21(100 \%)$ & $22(100 \%)$ & $27(100 \%)$ & $70(100 \%)$ \\
& Guest A & Guest B & Guest C & Total
\end{tabular}


Table 19 (continued)

\begin{tabular}{|c|c|c|c|c|c|}
\hline & $\begin{array}{c}\text { Guest } \\
\text { Speaker A }\end{array}$ & $\begin{array}{c}\text { Guest } \\
\text { Speaker B }\end{array}$ & $\begin{array}{c}\text { Guest } \\
\text { Speaker C }\end{array}$ & Total & $\chi^{2}(d f)$ \\
\hline \multicolumn{6}{|c|}{ The speaker was a good role model for me } \\
\hline Disagree & 0 & $1(4.5 \%)$ & 0 & $1(1.4 \%)$ & $5.41(6)$ \\
\hline Undecided & 0 & $1(4.5 \%)$ & $3(11.1 \%)$ & $4(5.7 \%)$ & \\
\hline Agree & $6(28.6 \%)$ & $7(31.8 \%)$ & $9(33.3 \%)$ & $22(31.4 \%)$ & \\
\hline Strongly agree & $15(71.4 \$)$ & $13(59.1 \%)$ & $15(55.6 \%)$ & $43(61.4 \%)$ & \\
\hline Total & $21(100 \%)$ & $22(100 \%)$ & $27(100 \%)$ & $70(100 \%)$ & \\
\hline
\end{tabular}

$* p<.05$.

Sub question 2.5 asks: What was the students' overall perception of the experience?

Table 21 (p. 70) presents the ratings of overall perceptions separately by schools as well as for the total sample of three schools. In general, the overall perception ratings were almost all in the agree or strongly agree categories and there were no differences across groups. The students seemed to find the overall experience motivating, entertaining, and informational, and they felt that they learned from it.

In addition to the Likert ratings that were presented for each survey item in Tables 18-21, Likert ratings for the items from each section (i.e., personality, content and effectiveness, technology, and overall perceptions) were averaged to form total scores for each category. Each total score was then assessed for normality by computing measures of skewness and kurtosis for each scale. Skewness and kurtosis values of 0 are indicative of a normal distribution, and values between -2 and +2 signify no problematic deviations from normality All measures of skewness and kurtosis for all scales were between the values of -2 and +2 ; thus, parametric statistics could be appropriately applied to the scales. 
Table 20. Student Technology Ratings for Industry Professional

\begin{tabular}{|c|c|c|c|c|c|c|}
\hline & & School A & School B & School C & Total & $\chi^{2}(d f)$ \\
\hline \multicolumn{7}{|c|}{ The quality of the audio was excellent } \\
\hline & Disagree & $5(23.8 \%)$ & $10(45.5 \%)$ & $10(37.0 \%)$ & $25(46.7 \%)$ & $5.61(6)$ \\
\hline & Undecided & $4(19 . .0 \%)$ & $2(9.1 \%)$ & $7(25.9 \%)$ & $13(18.6 \%)$ & \\
\hline & Agree & $10(47.6 \%)$ & $7(31.8 \%)$ & $9(33.3 \%)$ & $26(37.1 \%)$ & \\
\hline & Strongly agree & $3(9.5 \%)$ & $3(13.6 \%)$ & $1(3.7 \%)$ & $6(8.6 \%)$ & \\
\hline Total & & $21(100 \%)$ & $22(100 \%)$ & $27(100 \%)$ & $70(100 \%)$ & \\
\hline \multicolumn{7}{|c|}{ The quality of the video was excellent } \\
\hline & Strongly disagree & 0 & $4(18.25 \%)$ & 0 & $4(5.7 \%)$ & $27.24(8)^{*}$ \\
\hline & Disagree & $4(19.0 \%)$ & $8(36.4 \%)$ & $2(7.4 \%)$ & $14(20.0 \%)$ & \\
\hline & Undecided & $5(23.8 \%)$ & $7(31.8 \%)$ & $3(11.1 \%)$ & $15(21.4 \%)$ & \\
\hline & Agree & $10(47.6 \%)$ & $3(13.6 \%)$ & $18(66.7 \%)$ & $31(44.3 \%)$ & \\
\hline & Strongly agree & $2(9.5 \%)$ & 0 & $4(14.8 \%)$ & $6(8.6 \%)$ & \\
\hline Total & & $21(100 \%)$ & $22(100 \%)$ & $27(100 \%)$ & $70(100 \%)$ & \\
\hline
\end{tabular}

The projection screen was large enough to see the guest speaker comfortably

$\begin{array}{lccccc}\text { Undecided } & 0 & 1(4.5 \%) & 0 & 1(1.4 \%) & 3.46(4) \\ \text { Agree } & 10(47.6 \%) & 7(31.8 \%) & 13(48.1 \%) & 30(42.9 \%) & \\ \text { Strongly agree } & 11(52.4 \%) & 14(63.6 \%) & 14(51.9 \%) & 39(55.7 \%) & \\ & 21(100 \%) & 22(100 \%) & 27(100 \%) & 70(100 \%) & \end{array}$

During the session, the technology functioned properly

\begin{tabular}{lccccc} 
Strongly disagree & 0 & $1(4.5 \%)$ & $2(7.4 \%)$ & $3(4.3 \%)$ & $34.63(8)^{*}$ \\
Disagree & 0 & $7(31.8 \%)$ & $13(48.1 \%)$ & $20(28.6 \%)$ & \\
Undecided & $2(9.5 \%)$ & $7(31.8 \%)$ & $8(29.6 \%)$ & $17(24.3 \%)$ & \\
Agree & $14(66.7 \%)$ & $7(31.8 \%)$ & $4(14.8 \%)$ & $25(35.7 \%)$ & \\
& Strongly agree & $5(23.8 \%)$ & 0 & 0 & $5(7.1 \%)$ \\
Total & $21(100 \%)$ & $22(100 \%)$ & $27(100 \%)$ & $70(100 \%)$ \\
\hline
\end{tabular}

${ }^{*} p<.001$. 


\section{Table 21. Overall Student Perception Ratings for Industry Professional}

\begin{tabular}{|c|c|c|c|c|c|c|}
\hline & & School A & School B & School C & Total & $\chi^{2}(d f)$ \\
\hline \multicolumn{7}{|c|}{ This session motivated me } \\
\hline & Undecided & $1(4.8 \%)$ & 0 & $3(11.1 \%)$ & $4(15.7 \%)$ & $5.05(4)$ \\
\hline & Agree & $11(52.4 \%)$ & $9(40.9 \%)$ & $15(55.6 \%)$ & $35(50.0 \%)$ & \\
\hline & Strongly agree & $9(42.9 \%)$ & $13(59.1 \%)$ & $9(33.3 \%)$ & $31(44.3 \%)$ & \\
\hline Total & & $21(100 \%)$ & $22(100 \%)$ & $27(100 \%)$ & $70(100 \%)$ & \\
\hline \multicolumn{7}{|c|}{ This session entertained me } \\
\hline & Undecided & $2(9.5 \%)$ & $2(9.1 \%)$ & $5(18.5 \%)$ & $6(12.9 \%)$ & $2.68(4)$ \\
\hline & Agree & $11(52.4 \%)$ & $10(45.5 \%)$ & $15(55.6 \%)$ & $36(51.4 \%)$ & \\
\hline & Strongly agree & $8(38.1 \%)$ & $10(45.5 \%)$ & $7(25.9 \%)$ & $25(35.7 \%)$ & \\
\hline Total & & $21(100 \%)$ & $22(100 \%)$ & $27(100 \%)$ & $70(100 \%)$ & \\
\hline \multicolumn{7}{|c|}{ This session informed me } \\
\hline & Agree & $9(42.9 \%)$ & $7(31.8 \%)$ & $12(3.8 \%)$ & $28(40.0 \%)$ & $0.91(2)$ \\
\hline & Strongly agree & $12(57.1 \%)$ & $15(68.2 \%)$ & $15(55.6 \%)$ & $42(60.0 \%)$ & \\
\hline Total & & $21(100 \%)$ & $22(100 \%)$ & $27(100 \%)$ & $70(100 \%)$ & \\
\hline \multicolumn{7}{|c|}{ I felt that I learned something important during the session } \\
\hline & Undecided & 0 & 0 & $1(3.8 \%)$ & $1(1.4 \%)$ & $1.693(4)$ \\
\hline & Agree & $7(33.3 \%)$ & $7(31.8 \%)$ & $8(30.8 \%)$ & $22(31.9 \%)$ & \\
\hline & Strongly agree & $14(66.7 \%)$ & $15(68.2 \%)$ & $17(65.4 \%)$ & $46(66.7 \%)$ & \\
\hline Total & & $21(100 \%)$ & $22(100 \%)$ & $27(100 \%)$ & $70(100 \%)$ & \\
\hline
\end{tabular}

Table 22 presents the means and standard deviations for each scale broken apart by schools. As can be seen in Table 22, mean ratings for personality, content and effectiveness, and overall perceptions are all between 4 and 5 , but the technology ratings are noticeably lower (between 3 and 4). One-way Analyses of Variance (ANOVAs) were computed to compare the mean ratings across groups. Significant differences were found for the personality ratings, $F(2,67)=4.99, p<.01$, as well as for the technology ratings, $F(2,67)=$ $7.97, p<.001$. Post hoc Scheffé tests were then computed to determine which specific groups were different from each other. The post hoc test for personality indicated that Group A was 
rated significantly higher than Guest $\mathrm{C}(p<.05)$, but neither $\mathrm{A}$ nor $\mathrm{C}$ differed from $\mathrm{B}$ on personality. For technology, Group A was rated significantly higher than both Group B ( $p<$ $.001)$ and $\mathrm{C}(p<.05)$, but $\mathrm{B}$ and $\mathrm{C}$ were not different from each other.

Table 22. ANOVAs Comparing Student Overall Scores for Industry Professional

\begin{tabular}{lcccc}
\hline & $\begin{array}{c}\text { School A } \\
(N=21)\end{array}$ & $\begin{array}{c}\text { School B } \\
(N=22)\end{array}$ & $\begin{array}{c}\text { School C } \\
(N=27)\end{array}$ & \\
& $M(S D)$ & $M(S D)$ & $M(S D)$ & $F(2,67)$ \\
\hline Personality & $4.83(0.19)$ & $4.59(0.44)$ & $4.49(0.43)$ & $4.99^{*}$ \\
Content/Effectiveness & $4.62(0.28)$ & $4.60(0.38)$ & $4.51(0.44)$ & 0.59 \\
Technology & $3.89(0.50)$ & $3.26(0.60)$ & $3.49(0.48)$ & $7.97^{* *}$ \\
Overall perception & $4.48(0.43)$ & $4.58(0.45)$ & $4.36(0.47)$ & 1.41 \\
\hline
\end{tabular}

${ }^{*} p<01 . \quad{ }^{* *} p<001$.

\section{QuAlitative Findings}

This section will look at student responses from open-ended questions on the Student Post Survey (Appendix F). Qualitative method was used to analyze data. Data was entered in a Word table, responses were sorted and common themes or patterns were noted. Themes and patterns were entered into a Word table for ease in interpretation.

Further answering the second research question of, "What are the students' perceptions of their interaction with apparel industry professional who visited the classroom via Internet videoconferencing?" the following sub question (2.5) is specifically being addressed in these qualitative findings: What was the students' overall perception of the experience? Open-ended questions/items will be listed with responses categorized into themes with student response examples.

The first question/item was: What was the best part of using videoconferencing this session? 
After tabulation, four themes emerged in the findings. They are (a) student convenience; (b) personal gain or attention; (c) technology affordances (what technology could do); and (d) meeting a professional or mentor. Sixty-nine students responded out of 70 . Collectively, almost half (46\%) of the students reported that the technology affordances was the best part of the session, $13(19 \%)$ felt that the interaction with an industry professional was the best part of the session. Similarly, $12(17 \%)$ felt that convenience for the student was the best part. Lastly, $8(12 \%)$ felt that the personal gain they got from the session was the best part.

Student convenience was exampled by a comment from one student who said, "We got a chance to avoid traffic and still get information and still learn a lot." An example of personal gain was a comment by a student that said, "Getting to ask questions and the answers I got back." An example of the technology affordances theme was one statement by a student who said, "It was a pretty new experience." Another student said, "We could meet with her even though her busy schedule requires that she be present in another state" (Table 23).

Table 23. Themes from Students' Assessment of the Best Part of the Videoconferencing Session

\begin{tabular}{lcccccc}
\hline $\begin{array}{c}\text { Student } \\
\text { Groups }\end{array}$ & $\begin{array}{c}\text { Student } \\
\text { Convenience }\end{array}$ & $\begin{array}{c}\text { Personal } \\
\text { Gain }\end{array}$ & Technology & $\begin{array}{c}\text { Interaction } \\
\text { with a } \\
\text { Mentor }\end{array}$ & $\begin{array}{c}\text { Other/ } \\
\text { Missing }\end{array}$ & Total \\
\hline A & 10 & 4 & 4 & 3 & 0 & 21 \\
B & 2 & 3 & 13 & 3 & 1 & 22 \\
C & 0 & 1 & 16 & 7 & 2 & 26 \\
Totals & 12 & 8 & 32 & 13 & 3 & 69 \\
\hline
\end{tabular}


The second question/item was: What was the part you liked least about using videoconferencing this session?

After tabulation, two main themes emerged in the findings about the part they liked least of the videoconferencing session. They were (a) technical problems, and (b) feeling impersonal.

Sixty out of 70 students responded with single comments, one student responded with two comments. Collectively, half (50\%) of the students reported that the technology was the part they liked least of the session, $8(11 \%)$ felt that the impersonal feeling was the part they liked least of the session.

Technical problems was exampled by two comments: "The video lagged and froze, so I started to feel a disconnect, especially when I asked my question" and "The sound kept messing up." An example of the feeling impersonal theme were the following two comments: "That if she have been present, we would all interact more as a class ..." and "It seemed a little less personal. I think I prefer seeing someone in person." Table 24 lists findings.

Table 24. Themes from Students' Assessment of the Part They Liked Least of the Videoconferencing Session

\begin{tabular}{lcccccc}
\hline $\begin{array}{c}\text { Student } \\
\text { Groups }\end{array}$ & $\begin{array}{c}\text { Technology } \\
\text { Problems }\end{array}$ & Impersonal & Time & Other & Missing & Total \\
\hline A & 12 & 6 & 0 & 1 & 3 & $22^{\mathrm{a}}$ \\
B & 19 & 1 & 2 & 1 & 1 & $24^{\mathrm{a}}$ \\
C & 21 & 1 & 0 & 2 & 3 & 27 \\
Totals & 52 & 8 & 2 & 4 & 7 & 73 \\
\hline
\end{tabular}

${ }^{a}$ Three students made two comments which fell into two categories. 
The third question/item was: What is the most important thing you learned from this videoconferencing session?

After tabulation, six themes emerged in the findings. They were (a) industry professional perspectives; (b) technology possibilities; (c) career possibilities/job duties; (d) personal ethics; (e) industry preparation and skills; and (f) encouragement to go for your dreams.

Sixty-six students responded out of 70 . Sixteen $(24 \%)$ of the students reported that the most important thing they learned in the session was personal advice or ethics; $15(23 \%)$ felt that the most important thing they learned was industry needed skills/preparation; $11(17 \%)$ felt the most important thing they learned was career possibilities/job duties; and $9(14 \%)$ felt the most important thing they learned was encouragement to go for their dreams. Similarly, $9(14 \%)$ felt the most important thing they learned was being exposed to the industry professional perspective. Only $2(3 \%)$ felt that the technology affordances was the most important thing they learned.

Personal advice or ethics was exampled by a comment from one student who said, "Give your $100 \%$ in your work, be flexible always have a willingness and commitment to your employer." Another example was to "Be passionate and show intelligence in no matter what you do carry and develop a strong reputation ...." An example of industry professional perspectives was a comment by a student that said, "That is was not easy being a designer," another student wrote that they "learned the view of the industry from a professional's standpoint."

An example of the technology possibilities is one statement by a student who said "The possibilities are endless when connecting through the Internet." An example of the 
industry needed skills/preparation theme is a comment from a student that said "[I need to] continue what I am doing, learning everything I can and take networking seriously." Another student said "[I need to] learn computer aided software." An example of the encouragement theme to go for your dreams was a statement: "She reinforced following your heart" and "It's key to make sure you are passion about your job and not be in it just for the money." Table 25 lists findings.

Table 25. Themes from Student Responses of the Most Important Thing They Learned in the Videoconferencing Session

\begin{tabular}{|c|c|c|c|c|c|c|c|c|c|}
\hline $\begin{array}{l}\text { Student } \\
\text { Groups }\end{array}$ & $\begin{array}{c}\text { Industry } \\
\text { Professional } \\
\text { Perspectives }\end{array}$ & $\begin{array}{l}\text { Technol- } \\
\text { ogy } \\
\text { Possibili- } \\
\text { ties }\end{array}$ & $\begin{array}{c}\text { Career } \\
\text { Possibili- } \\
\text { ties/Job } \\
\text { Duties }\end{array}$ & $\begin{array}{l}\text { Personal/ } \\
\text { Advice } \\
\text { Ethics }\end{array}$ & $\begin{array}{c}\text { Industry } \\
\text { Needed } \\
\text { Skills/ } \\
\text { Prep }\end{array}$ & $\begin{array}{l}\text { Go for } \\
\text { Your } \\
\text { Dreams }\end{array}$ & Other & Missing & Totals \\
\hline A & 3 & 1 & 3 & 6 & 6 & 1 & 1 & & 21 \\
\hline B & 2 & 0 & 1 & 8 & 5 & 3 & 2 & 1 & 22 \\
\hline $\mathrm{C}$ & 2 & 1 & 7 & 2 & 4 & 5 & 1 & 3 & 27 \\
\hline Totals & 9 & 2 & 11 & 16 & 15 & 9 & 4 & 4 & 70 \\
\hline
\end{tabular}

The fourth question/item asked students to choose one word that described the session.

Sixty-eight out of 70 students responded. Eleven (16\%) listed the single word to describe the session as "informative," $10(15 \%)$ listed the single word as "interesting," 5 $(8 \%)$ listed the word as "great," $3(4 \%)$ "educational," and $3(4 \%)$ as "beneficial." Other oneword descriptions included "motivational," "awesome," "fun," and "good" (Table 26).

The fifth question/item was students were asked to share any other questions or comments that they would like. Some of the comments included, "This was a fun, new, interesting experience," "I really enjoyed it and would love to do it again," "I think these should be done more often. Real experiences from the work field motivate students to take 
their education seriously," "I think this is a great idea to have in classrooms," "Just because we get book information but it's important for us to know real life stuff and being able to reach people who would normally be too busy to come out is awesome on top of that interaction and asking them real questions is awesome." Additional comments included, "It was really exciting, the speaker was great!" "I enjoyed this experience and feel that it has well informed me. I am glad that I was able to be a part of this experience" and "Thank you."

The most negative comment was: "I participated in many webinars through work and it seem that the issue is always the same-technical issues. this time was the volume. I have no problems with webinars if all technology is working properly."

\section{Table 26. Students' Choice of Single Word Describing the Session}

\begin{tabular}{ccccccc}
\hline $\begin{array}{c}\text { Collective Student } \\
\text { Choice of Single } \\
\text { Word That Described } \\
\text { the Session }\end{array}$ & Informative & Interesting & Great & Educational & Beneficial & Totals \\
\hline & $11(16 \%)$ & $10(15 \%)$ & $5(8 \%)$ & $3(4 \%)$ & $3(4 \%)$ & 32 \\
\hline
\end{tabular}

Research Question Three: What are fashion instructors' perceptions of the Internet videoconferencing experience between their students and apparel industry professionals?

Sub question 3.1 asks: Were instructor's expectations met?

The instructors' expectation that students would learn about real world relationships was exceeded. Collectively, two instructors only agreed to the statement that students would learn about real world relationships; after the session, all three strongly agreed that the students learned about real world relationship. In the area of agreeing that the guest speaker would be engaging and interesting, collectively, two instructors only agreed to that statement. 
After the session, all three strongly agreed that the guest speaker was engaging and interesting. For the statement from the pre-survey (Appendix C) about the guest speaker promoting his own company, two instructors were undecided, while one strongly agreed that they expected the guest speaker to promote his company. After the session, only one strongly agreed that the industry professional had promoted their company while the other two instructors strongly disagreed (Tables 27 and 28).

\section{Table 27. Pre-Session Collective Instructor Expectations}

\begin{tabular}{|c|c|c|c|c|c|}
\hline & $\begin{array}{l}\text { Strongly } \\
\text { Disagree }\end{array}$ & Disagree & Undecided & Agree & $\begin{array}{l}\text { Strongly } \\
\text { Agree }\end{array}$ \\
\hline $\begin{array}{l}\text { 1. I believe the students will learn } \\
\text { about real world relationships. }\end{array}$ & & & & 2 & 1 \\
\hline $\begin{array}{l}\text { 2. I believe that the guest speaker will } \\
\text { be engaging and interesting. }\end{array}$ & & & & 2 & 1 \\
\hline $\begin{array}{l}\text { 3. I believe the guest speaker promoted } \\
\text { his company/film. }\end{array}$ & & & 2 & & 1 \\
\hline
\end{tabular}

Table 28. Post-Session Collective Instructor Expectations

\begin{tabular}{|c|c|c|c|c|c|}
\hline & $\begin{array}{l}\text { Strongly } \\
\text { Disagree }\end{array}$ & Disagree & Undecided & Agree & $\begin{array}{c}\text { Strongly } \\
\text { Agree }\end{array}$ \\
\hline $\begin{array}{l}\text { 1. The students learned about real } \\
\text { world relationships. }\end{array}$ & & & & & 3 \\
\hline $\begin{array}{l}\text { 2. The guest speaker was engaging and } \\
\text { interesting. }\end{array}$ & & & & & 3 \\
\hline $\begin{array}{l}\text { 3. The guest speaker promoted his } \\
\text { company/film. }\end{array}$ & 2 & & & & 1 \\
\hline
\end{tabular}

Sub question 3.2 asks: According to the instructors, what session objectives were met? 
Session student learning objectives were developed by the researcher. Instructors were asked on the post-survey (Appendix F), via Likert scale, if they felt that those objectives had been met. Two instructors agreed that as a result of the session, they felt that the students would be able to describe the duties of an employment position in the apparel industry, one instructor strongly agreed. Two instructors agreed that as a result of the session, they felt that the students would be able to relate the theory they are learning in the classroom to real life application, one instructor strongly agreed. Two instructors agreed that as a result of the session, they felt that the students will be able to describe the attitudes necessary for career success, one instructor strongly agreed (Table 29).

Table 29. Post-Session Instructors' Assessment of Met Learning Objectives

\begin{tabular}{|c|c|c|c|c|c|}
\hline & $\begin{array}{l}\text { Strongly } \\
\text { Disagree }\end{array}$ & Disagree & Undecided & Agree & $\begin{array}{c}\text { Strongly } \\
\text { Agree }\end{array}$ \\
\hline $\begin{array}{l}\text { 1. As a result of this session, I feel that } \\
\text { the students will be able to describe the } \\
\text { duties of an employment position in the } \\
\text { apparel industry. }\end{array}$ & & & & 2 & 1 \\
\hline $\begin{array}{l}\text { 2. As a result of this session, } I \text { feel that } \\
\text { the students will be able to relate the } \\
\text { theory they are learning in the } \\
\text { classroom to real life application. }\end{array}$ & & & & 2 & 1 \\
\hline $\begin{array}{l}\text { 3. As a result of this session, I feel that } \\
\text { the students will be able to describe the } \\
\text { attitudes necessary for career success. }\end{array}$ & & & & 2 & 1 \\
\hline
\end{tabular}

Sub question 3.3 asks: How did instructors rate the technology of the session? Instructor post-surveys (Appendix D) reported instructors' ratings of technology during the session using Likert scale data items. 
Two instructors agreed that the audio was excellent, while one disagreed. Two instructors disagreed that the video was excellent, one instructor agreed. All three instructors agreed that the projection screen was large enough to see the guest speaker comfortably. When asked if during the session, the technology functioned properly, the responses were disagree, undecided and agree (Table 30).

Table 30. Instructor Post-Session Responses to Technology

\begin{tabular}{|c|c|c|c|c|c|}
\hline & $\begin{array}{l}\text { Strongly } \\
\text { Disagree }\end{array}$ & Disagree & Undecided & Agree & $\begin{array}{l}\text { Strongly } \\
\text { Agree }\end{array}$ \\
\hline The quality of the audio was excellent. & & 1 & & 2 & \\
\hline The quality of the video was excellent. & & 2 & & 1 & \\
\hline $\begin{array}{l}\text { The projection screen was large enough } \\
\text { to see the guest speaker comfortably. }\end{array}$ & & & & 3 & \\
\hline $\begin{array}{l}\text { During the session, the technology } \\
\text { functioned properly. }\end{array}$ & & 1 & 1 & 1 & \\
\hline
\end{tabular}

Sub question 3.4 asks: How did the instructors rate the student benefits of the session?

All three instructors felt that the guest speaker was a good role model for their students and that overall, the presentation was a worthwhile, educational experience. Two instructors strongly agreed that the guest speaker provided career options for their students, one agreed. Two instructors strongly agreed that the session motivated their students, one agreed. Two instructors agreed that the session entertained their students, one strongly agreed. Two instructors strongly agreed that the session informed their students, while one only agreed (Table 31 ). 


\section{Table 31. Instructors' Ratings on Student Benefits of the Session}

\begin{tabular}{|c|c|c|c|c|c|}
\hline & $\begin{array}{l}\text { Strongly } \\
\text { Disagree } \\
\end{array}$ & Disagree & Undecided & Agree & $\begin{array}{l}\text { Strongly } \\
\text { Agree }\end{array}$ \\
\hline $\begin{array}{l}\text { The guest speaker was a good role } \\
\text { model for my students. }\end{array}$ & & & & & 3 \\
\hline $\begin{array}{l}\text { The guest speaker provided career } \\
\text { options for my students. }\end{array}$ & & & & 1 & 2 \\
\hline $\begin{array}{l}\text { Overall, the presentation was a } \\
\text { worthwhile, educational experience. }\end{array}$ & & & & & 3 \\
\hline This session motivated my students. & & & & 1 & 2 \\
\hline This session entertained my students. & & & & 2 & 1 \\
\hline This session informed my students. & & & & 1 & 2 \\
\hline
\end{tabular}

Sub question 3.5 asks: How did instructors rate the feasibility of the Internet session?

Instructor post-surveys (Appendix D) reported their view of the feasibility of using internet videoconferencing with their students via a Likert scale.

Two instructors agreed that the session represented a practical and inexpensive way to bring in guest speakers to their classroom, one instructor strongly agreed. Two instructors strongly agreed that they would like to bring guests speakers into their classroom via Internet videoconferencing, one agreed. Two instructors strongly agreed that they planned to bring guest speakers into their classroom via Internet videoconferencing, one was undecided. One instructor was undecided that it would be easy for her to set up and execute a videoconferencing session like the one experienced without the help of the researcher, one instructor agreed and one instructor strongly agreed. Two instructors agreed that it would be easy to find guest speakers who would visit their students via Internet videoconferencing, one was undecided (Table 32). 
Table 32. Instructors' Rating for Feasibility of the Internet Videoconferencing Session

\begin{tabular}{|c|c|c|c|c|c|}
\hline & $\begin{array}{l}\text { Strongly } \\
\text { Disagree }\end{array}$ & Disagree & Undecided & Agree & $\begin{array}{c}\text { Strongly } \\
\text { Agree }\end{array}$ \\
\hline $\begin{array}{l}\text { The session represents a practical and } \\
\text { inexpensive way to bring in guest } \\
\text { speakers to my classroom. }\end{array}$ & & & & 2 & 1 \\
\hline $\begin{array}{l}\text { I would like to bring guest speakers } \\
\text { into my classroom via Internet } \\
\text { videoconferencing. }\end{array}$ & & & & 1 & 2 \\
\hline $\begin{array}{l}\text { I plan to bring guest speakers into my } \\
\text { classroom via Internet } \\
\text { videoconferencing. }\end{array}$ & & & 1 & & 2 \\
\hline $\begin{array}{l}\text { It would be easy for me to set up and } \\
\text { execute a videoconferencing session } \\
\text { like this one without the help of the } \\
\text { researcher. }\end{array}$ & & & 1 & 1 & 1 \\
\hline $\begin{array}{l}\text { It would be easy for me to find guest } \\
\text { speakers who would visit my students } \\
\text { via Internet videoconferencing. }\end{array}$ & & & 1 & 2 & \\
\hline
\end{tabular}

Sub question 3.6 asks: What was the instructors' overall perception of the experience? Instructor responses to post-survey (Appendix D) open-ended questions revealed that the part that they liked best about using videoconferencing session was the live interaction, that they were able to stay in class and not have to drive anywhere (reported as a big advantage), and the fact that a senior manager was talking to her class about career paths, career nurturing and team communication. Instructor responses to post-surveys (Appendix D) reported that the part that instructors liked least about using videoconferencing in the session were the choppy visual impact, low sound quality; unclear video image; and equipment. Lastly, instructors were asked to described their perspective of the session in one word. The responses were "wonderful," "educational." and "good." 
Research Question Four: What are apparel industry professionals' perceptions of interacting with fashion students via Internet videoconferencing?

Sub question 4.1 asks: How did apparel industry professionals feel that they benefited the students as a result of the videoconference session?

Responses included, “. . . it gave them hope that they can do it too," "I think it gave them a clearer idea of what to expect in the workplace; that in all likelihood they are not going to get rich as a textile designer; that designing textiles is not about what you personally think looks great but in meeting the needs of a particular company ... some of the biggest challenges are not in the work itself but in office politics. I hope I was able to convey the positive benefits of textile design ... doing something you are passionate about" and "[It] showed them one of the paths throughout their career."

Sub question 4.2 asks: What was the apparel industry professional's overall perception of the experience?

In terms of technology effectiveness, industry professionals reported their responses on a Likert scale rating (Tables 33, 34, and 35, pp. 83-84). Table 36 (p. 84) shows collective industry professional ratings. Two industry professionals rated the quality of the audio neutral, the statement that "the quality of the video was excellent" was rated neutral by two instructors and one instructor agreed that the video quality was excellent. When presented with the statement that the technology functioned properly during the session, one industry professional was neutral, and one agreed. One respondent did not rate this statement. For the statement, "I could see each student clearly as he asked his/her question," all three instructors agreed. 
Table 33. Post-Survey Industry Professional A Assessment of Technology

\begin{tabular}{|c|c|c|c|c|c|}
\hline & $\begin{array}{l}\text { Strongly } \\
\text { Disagree }\end{array}$ & Disagree & Neutral & Agree & $\begin{array}{l}\text { Strongly } \\
\text { Agree }\end{array}$ \\
\hline \multicolumn{6}{|l|}{ The quality of the audio was excellent. } \\
\hline The quality of the video was excellent. & & & $\mathrm{X}$ & & \\
\hline \multicolumn{6}{|l|}{$\begin{array}{l}\text { During the session, the technology } \\
\text { functioned properly. }\end{array}$} \\
\hline $\begin{array}{l}\text { I could see each student clearly as he } \\
\text { asked his/her question. }\end{array}$ & & & & $\mathrm{X}$ & \\
\hline Comments: "It's a fun experience." & & & & & \\
\hline
\end{tabular}

Table 34. Post-Survey Industry Professional B Assessment of Technology

\begin{tabular}{|c|c|c|c|c|c|}
\hline & $\begin{array}{l}\text { Strongly } \\
\text { Disagree }\end{array}$ & Disagree & Neutral & Agree & $\begin{array}{l}\text { Strongly } \\
\text { Agree }\end{array}$ \\
\hline The quality of the audio was excellent. & & & $\mathrm{X}$ & & \\
\hline The quality of the video was excellent. & & & $\mathrm{X}$ & & \\
\hline $\begin{array}{l}\text { During the session, the technology } \\
\text { functioned properly. }\end{array}$ & & & \multicolumn{3}{|c|}{$\mathrm{X}$} \\
\hline $\begin{array}{l}\text { I could see each student clearly as he } \\
\text { asked his/her question. }\end{array}$ & & & \multicolumn{3}{|c|}{$X$} \\
\hline $\begin{array}{l}\text { Comments: Researcher's note: The spe } \\
\text { it. }\end{array}$ & 's image $\mathrm{fr}$ & during the & sion. The & ker was & ware of \\
\hline
\end{tabular}




\section{Table 35. Post-Survey Industry Professional C Assessment of Technology}

\begin{tabular}{|c|c|c|c|c|c|}
\hline & $\begin{array}{l}\text { Strongly } \\
\text { Disagree }\end{array}$ & Disagree & Neutral & Agree & $\begin{array}{l}\text { Strongly } \\
\text { Agree }\end{array}$ \\
\hline The quality of the audio was excellent. & & & $\mathrm{x}$ & & \\
\hline The quality of the video was excellent. & & & & $\mathrm{x}$ & \\
\hline $\begin{array}{l}\text { During the session, the technology } \\
\text { functioned properly. }\end{array}$ & & & $\mathrm{X}$ & & \\
\hline $\begin{array}{l}\text { I could see each student clearly as he } \\
\text { asked his/her question. }\end{array}$ & & & & $X$ & \\
\hline
\end{tabular}

\section{Table 36. Post-Survey Collective Industry Professional Assessment of Technology}

\begin{tabular}{|c|c|c|c|c|c|}
\hline $\begin{array}{l}\text { Post-Survey Collective Industry } \\
\text { Professional Collective Assessment of } \\
\text { Technology }\end{array}$ & $\begin{array}{l}\text { Strongly } \\
\text { Disagree }\end{array}$ & Disagree & Neutral & Agree & $\begin{array}{c}\text { Strongly } \\
\text { Agree }\end{array}$ \\
\hline The quality of the audio was excellent. & & & 2 & & \\
\hline The quality of the video was excellent. & & & 2 & 1 & \\
\hline $\begin{array}{l}\text { During the session, the technology } \\
\text { functioned properly. }\end{array}$ & & & 1 & 1 & \\
\hline $\begin{array}{l}\text { I could see each student clearly as he } \\
\text { asked his/her question. }\end{array}$ & & & & 3 & \\
\hline
\end{tabular}

Comments: Researcher's note: The speaker's image froze during the session. The speaker was not aware of it. 
Responses from the industry professionals' post-survey, when asked a single word to describe the experience, reported the following, "cool," "interesting," and "positive."

When asked the best part of using videoconferencing in this session, the following was reported: "Questions that students asked," "Being able to communicate with students 1000 miles away" and "Hearing student questions and concerns and trying to answer them honestly."

When asked what part was liked least about the videoconferencing session and what improvements were needed, the following responses were given by the industry professionals: "Not sure where to look, should I look at the screen or the camera?" "The audio went in and out but I believe the bug was on my end, and it was an easy fix," and "[I] couldn't see the entire class, and would like a more professional setting."

When asked "Would you be willing to do this again," the responses were "Absolutely yes, because it is what the younger generation can relate to," "Yes, it was a fulfilling experience;" and "I would but scheduling is the most challenging part of it since I work off site four days a week."

When asked for industry professionals' perception or comments about the students that they worked with during the session, one response was: "They seemed quite intelligent by the questions they asked." Another industry professional stated that the students showed student mentality and asked intelligent questions, another stated that very few seemed engaged in with their major.

Sub question 4.3 asks: What factors motivate the fashion industry professional to participate in the Internet videoconferencing session? 
Responses were taken from industry professionals' pre- and post-surveys (Appendices $\mathrm{G}$ and $\mathrm{H}$ ) and reported qualitatively. Factors that motivate the fashion industry professional in engaging in the Internet videoconferencing interaction with the students were reported in the pre-survey (Appendix G). Responses were: “. . . love to help in any way, and this is easy, I can sit in front of a camera and not have to travel, but am still able to communicate the info," "I like working with people who have a passion for textile design and are willing to put their all into it. It can be an incredibly creative field. It is my hope to be able to expand my experiences in teaching," and "I am passionate about my industry and what I do, and I would like to spread that passion to entice the younger generation to join this industry." Post-survey (Appendix H) results report that they would be motivated to participate “. . because it's easy and effective," "To share their knowledge, experience and passion [with students]," and one industry professional wrote: "If the students felt it was worthwhile and gave them a glimpse into the real working world, I would do another videoconference."

Sub question 4.4 asks: What factors hinder the fashion industry professional in engaging in the Internet videoconferencing interaction with the students?

Responses were taken from industry professionals' pre- and post-surveys (Appendices $\mathrm{G}$ and $\mathrm{H}$ ). Factors that hindered the fashion industry professional in engaging in the Internet videoconferencing interaction with the students were reported in the pre-survey (Appendix G) are "People who are afraid of the technology because it sounded scary," and a "lack of time." Post- survey (Appendix H) results report, "Not having a webcam," "Scheduling conflict with my work," and "Time." 
Industry professionals were asked if they had other colleagues that would be willing to participate in guest speaking via Internet videoconferencing and what would motivate those colleagues to participate? Responses were "Yes, I have others who would participate. They are also motivated to help students," "Possibly. Motivation is about caring for others and helping students," and "Yes, the passion to share their experiences."

Research Question Five: What are the hindrances to the process of setting up Internet videoconferencing guest speaking sessions in the college or university classroom?

Responses are reported according to researcher notes. There were two main hindrances reported in setting up the videoconferencing sessions. They are scheduling issues and school technology issues.

In the area of scheduling issues, it was difficult to find industry professionals who were available at the same time that the class was normally held. One example was a potential industry professional that was very interested in speaking to students. He worked overseas and because of the time differences, was available only after 4:00 Pacific Standard. time. It was difficult to find classes (for which he was the best candidate to speak) that met after 4:00. For that reason, he could not be chosen as a participant in the study. Another example is of an industry professional that worked daily and had to take a day off work to be available to speak to the class. Other industry professionals could not be chosen because of their time commitment to their employer; they were not available during the class times.

In the area of school technology issues, one school had a policy where no outside person was allowed to use their computer technology or equipment on the campus computer systems, which impacted the researcher's ability to bring her own webcam to the school for the project. The instructor eventually purchased a webcam to use on her school issued laptop. 
Another potential issue was firewalls and access blockages. Fortunately, Skype software was loaded onto laptops for all three schools and webcam software was loaded onto a laptop for two of the schools while the other laptop had a built-in camera. 


\section{CHAPTER 5}

\section{SUMMARY, DISCUSSION, AND RECOMMENDATIONS}

This study was conducted to explore the efficacy, benefits and student perceptions of using videoconferencing with Internet software and a web camera to connect college and university fashion students with apparel industry professionals.

This chapter will elaborate on the results from the previous chapter and contains a summary, discussion, implications, limitations, future research recommendations, and conclusion. The findings are organized by each research question. The interpretation of the findings is based on the researcher's qualitative analysis and categorization of open-ended questions, the comparison of frequency distributions of responses, and quantitative statistics.

\section{SUMMARY OF THE STUdY}

This mixed-method introductory study examined the efficacy, benefits, and student perceptions of using videoconferencing with Internet software and a web camera to connect college and university fashion students with apparel industry professionals. This was a multiple (three) case study using sets of partner participants which include the instructor/student group as the school partner and the fashion industry professional as the industry partner. This study examined perceptions from the perspective of instructors, students, and fashion industry professionals. The data collection instruments were developed 
and piloted by the researcher. Surveys for the student, instructor, and apparel industry professionals used 5-point Likert scales of measurement, multiple choice, and open-ended questions. Additional notes were taken by the researcher to address one of the research questions.

There were five research questions:

1. What are students', instructors', and apparel industry professionals' expectations before participating in an Internet videoconferencing session?

2. What are students' perceptions of their interaction with apparel industry professionals who visited the classroom via Internet videoconferencing?

2.1 Were student expectations met after the videoconferencing session?

2.2 How do the students rate the fashion industry professional's perceived personality traits?

2.3 What are the students' perception of the fashion industry professional's effectiveness and content knowledge?

2.4 How did technology impact the experience for the students?

2.5 What was the students' overall perception of the experience?

3. What are fashion instructors' perceptions of the Internet videoconferencing experience between their students and apparel industry professionals?

3.1 Were instructor's expectations met?

3.2 According to the instructors, what session objectives were met?

3.3 How did instructors rate the technology of the session?

3.4 How did instructors rate student benefits of the session?

3.4 How did instructors rate the feasibility of the Internet session?

3.5 What was the instructors' overall perception of the experience?

4. What are apparel industry professionals' perceptions of interacting with fashion students via Internet videoconferencing? 
4.1 How did apparel industry professionals feel that they benefited the students as a result of the videoconference session?

4.2 What was the apparel industry professionals' overall perception of the experience?

4.3 What factors motivate the fashion industry professional to participate in the Internet videoconferencing session?

4.4 What factors hinder the fashion industry professional in engaging in the Internet videoconferencing interaction with the students?

5. What are hindrances to setting up Internet videoconferencing guest speaking sessions in the college or university classroom?

The review of literature discusses several areas including school/industry partnerships, guest speakers, videoconferencing in education, using Skype for videoconferencing, and Skype studies.

The population for this study were college and university fashion students, the instructors who teach fashion design courses, and apparel industry professionals. The convenience sample of three instructors was obtained through researcher acquaintances. The students of those instructors were the students used in this study. A convenience sample of three apparel industry professionals was obtained from researcher acquaintance, professional social networking site, and an Internet search engine.

\section{STUdY Findings}

Research Question One: What are students', instructors', and apparel industry professionals' expectations before participating in an Internet videoconferencing session?

In response to this question, student participants tended to respond similarly.

In Rowland's (2007) study with guest lecturers, Rowland asked students to develop a set of expectations that they had for a planned guest speaker. This study asked the students, 
instructors, and industry professionals to state their level of agreement with expectation statements adapted from Rowland's study. The statement topics that were rated by all study participants were that there would be learning about real world relationships, the guest speaker would be engaging and interesting, and that the guest speaker would promote his firm. Most (54\%) of the students across all groups agreed or strongly agreed that they expected to learn about real world relationships. Most (57\%) agreed or strongly agreed that they expected to find the guest speaker to be engaging and interesting and only $40 \%$ agreed or strongly agreed that they would find that the guest speaker promoted his/her company.

Research Question Two: What are students' perceptions of their interaction with apparel industry professionals who visited the classroom via Internet videoconferencing?

Sub question 2.1 asks. Were student expectations met after the videoconferencing session?

In this study, the expectations that there would be real world relationship learning and the guest speaker would be engaging and interesting were exceeded. The expectation that the guest speaker would promote his firm was not met. In Rowland's (2007) study on guest speaker expectations, he found that all student expectations of the guest speakers were met.

Sub question 2.2 asks: How do the students rate the fashion industry professional's perceived personality traits?

Almost all speaker perceived personality traits were rated overwhelmingly with agree or strongly agree. Significant differences were found for "The guest speaker was creative and imaginative" and "The guest speaker was energetic, positive, and enthusiastic." For creativity and imagination, the differences mostly occurred between the agree and strongly agree ratings; however, guest speaker B had a greater frequency of undecideds and disagrees. For 
the energy variable, most of the differences occurred between agree and strongly agree, such that guest speaker A received $90.5 \%$ strongly agree, guest speaker B received $68.2 \%$ strongly agree, and guest speaker $\mathrm{C}$ received $44.4 \%$ strongly agree. One possible explanation for the difference could be that guest speaker A was a fashion designer, a profession that almost all fashion students know about and many desire to become. The other two guest speakers had employment positions that were not well known, less "glamorous," and not as popular as a fashion designer. Pajares (2004) suggested that modeling affects motivation by instilling behavioral outcome expectations, especially when the model is someone who is significant to the observer, i.e., a purposed expert or someone who is effective at doing what the observer would like to see in his own life (Mikulas, n.d.). Becoming a designer is what many fashion students desire as a career goal. Being a designer is perceived as a coveted position; therefore, someone in that position would appear more captivating than someone in a less "glamorous" position. Mikulas suggests that guest experts can have an important influence on their student audiences. People tend to pay more attention to someone who has a position that they would like to obtain.

Sub question 2.3 asks What are the students' perception of the fashion industry professional's effectiveness and content knowledge? All speakers were given very good ratings on the variable of content and effectiveness; however, a surprising finding occurred. When students were asked if they would like to have more Internet videoconferencing events like the one they experienced, only $69 \%$ of the students from school A responded to this statement as agree or strongly agree. Interestingly, the same guest speaker (A) received the highest mean ratings in agreement in the area of personality and $99 \%$ of the students from 
school A agreed or strongly agreed that they would like to see this guest speaker invited back to speak to another class. This is inconsistent.

Sub question 2.4.asks: How did technology impact the experience for the students?

Technology issues received the lowest rating across all groups. This is consistent with the literature. In Daley et al.'s (2008) study, students were critical of technology issues. They pointed out issues of pixilation, echo, feedback, and delay in auditory feed. Ryobe, in 2008, revealed that one drawback to using Skype for classroom use is that of sound quality. He said that sound quality turned out to be poorer in a university environment than at home (Ryobe, 2008). Also in Ryobe's study, audio and video image problems occurred frequently as it did in this study. Most students in this study were tolerant of the sound and video problems even though they expressed their dislike of the issue. For the most part, the technology was adequate enough to communicate effectively. This is an area in the future that should be addressed so that maximum benefit can occur with this technology and interaction. More research is needed to find out what can be done to insure maximum and smooth interaction and transmission over the Internet.

Sub question 2.5. asks: What was the students' overall perception of the experience? The students in this study found overall experience to be very good. As in similar studies, student response was favorable. In a study by Ryobe (2008), students commented that the Skype class had been "fun and useful."

When students from this study were asked what they liked best about the interaction, $19 \%$ of the answers fell into the category of being able to interact and listen to an industry professional. Weber and Lieberman (n.d.) agree that guest experts can expose students to different perspectives on course content. Research revealed when college students are given 
the opportunity to explore career choices, they tended to have more clarity and make more realistic decisions about their careers (Threlkeld, 1935). Student comments from this study that evidenced its value and benefit include: "I think these should be done more often. Real experiences from the work field motivate students to take their education seriously," "I think this is a great idea to have in classrooms. Just because we get book information but it's important for us to know real life stuff, and being able to reach people who would normally be too busy to come out is awesome. On top of that interaction and asking them real questions is awesome!"

Research Question Three: What are fashion instructors' perceptions of the Internet videoconferencing experience between their students and apparel industry professionals?

Sub question 3.1 asks: Were instructors' expectations met?

All the instructors strongly agreed that their students had learned about real world relationships and that the guest speaker had been engaging and interesting. Instructor expectations in this area were exceeded. Related to the the topic about their students learning about real world relationships, one instructor commented that what she liked best about the session was that a senior manager was talking to her class about career paths, career nurturing and team communication. Almost any instructor would appreciate having their students hear this information. The instructors' expectation that the guest speaker would promote his firm were not met according to two of the instructors. They were undecided in their expectation before the session, and after the session, they disagreed that the guest speaker promoted his firm.

Sub question 3.2 asks: According to the instructors, what session objectives were met? 
All the instructors agreed or strongly agreed that student learning objectives could be met and that they were met during the study. A follow-up quiz could possibly be given to the students to further prove the fact that those objectives were met.

Sub question 3.3 asks: How did instructors rate the technology of the session?

This area received the lowest ratings among and between all participants. Instructors were more pleased with the audio than the video. As stated previously, this area needs improvement. Working with an IT person could help the school be able to troubleshoot minor Skype technology issues. Schools should purchase the very best web cams to get the maximum benefit from this technology.

Sub question 3.4 asks: How did instructors rate student benefits of the session?

There was unanimous strong agreement that the guest speaker provided a good role model for their students and the presentation was a worthwhile educational experience. The benefit of guest speakers has long been substantiated in research literature. Using Internet videoconferencing is a wonderful tool to bring those guest speakers into the classroom in order to benefit the students. Cockrell (2002) found that direct experience enhances the ability of students to make career decisions and the stability of that decision and that direct experience with healthcare experts (for his study) impacted student decisions about nursing (a chosen profession).

Sub question 3.5 asks: How did instructors rate the feasibility of the Internet session?

All instructors either agreed or strongly agreed that the session represented a practical and inexpensive way to bring guest speakers into their classroom. They also agreed or strongly agreed that they would like to bring guest speakers this way to their classroom in the future. They were undecided, though, if it would be easy to do so, or if it would be easy for 
them to bring guest speakers. The researcher taught two of the instructors how to download Skype and connect with the researcher via Skype. It took less than 10 minutes for each instructor to complete the download and connection. It would be easy for a school or department to provide training to its instructors on how to download and use Skype.

Sub question 3.6 asks: What was the instructors' overall perception of the experience? Instructors liked not having to travel to see a guest speaker who with this technology could be anywhere in the world, engaging and conversing with the audience of students (Cogburn, n.d.). Instructors also liked the new perspective that the industry professional brought into the classroom, especially when the guest speaker mentioned terms that students were learning about. In the Lim and Freed (2009) study, an instructor's comment was: “. . I hope to be making videoconferencing a regular part of my curriculum. This sounds so exciting!" Another comment was: "It is in the use of videoconferencing that teachers become aware of the possibilities to enhance their curriculum" (p. 439).

Research Question Four: What are apparel industry professionals' perceptions of interacting with fashion students via Internet videoconferencing?

Sub question 4.1 asks: How did apparel industry professionals feel that they benefited the students as a result of the videoconference session?

The industry professionals felt that they really helped the student. They liked working interacting with the students. In a study by Zerr and Pulcher (2008), professionals interacted with students in a mentor like position via Internet videoconferencing. They commented, "What a great idea. I felt like I could give encouragement and feedback as if I were in the room." "I see this being a big part of the assessment process for future classes" (p. 90). In this study, one of the industry professionals said, "I think I gave them a clearer idea of what to 
expect in the workplace." Pajares (2004) found that guest speakers can help build interest in the subject matter since these guests that actually work in "the field" can provide realistic perceptions of what particular employment positions entail. Another guest speaker in the Zerr and Pulcher study said, "It was fun and interesting, a great way to communicate and educate upcoming RNs or nursing students" (p. 90).

Sub question 4.2 asks: What was the apparel industry professional's overall perception of the experience?

Industry professionals loved the experience. They really wanted to "give back" and help the students. This was a pleasant, yet unexpected finding in this study that should increase the prospect that industry professionals may make themselves available to connect with students in this way.

Sub question 4.3 asks: What factors motivate the fashion industry professional to participate in the Internet videoconferencing session?

These guest speakers are motivated by the passion they have for their jobs or for the industry. They wanted to give back. They wanted to encourage students who are coming up in the field.

Sub question 4.3 asks: What factors hinder the fashion industry professional in engaging in the Internet videoconferencing interaction with the students?

Responses from participants included time constraints. Most industry professionals work full time and cannot take off from work to be a part of a videoconference. Some industry professionals may unjustifiably believe that the technology is too difficult to use. Instructors would have to work out times where their students and the guest speaker can connect. This might be able to occur after school or during certain school-wide free times. 
Some schools have, for example, around lunch time as university hour when classes are not scheduled. Instructors might also train their acquaintances (who may be guest speakers in the future) how to use Skype so that they won't be afraid of the technology.

Research Question Five: What are the hindrances of setting up Internet videoconferencing in the classroom with college and university fashion students?

In the Sedgwick and Spiers (2009) study, a service was established to set up appointments between the guest speaker and the classroom. Before the service was established, there was a need for several contacts to confirm the videoconference session bookings and to perform a test run to ensure connection stability (Sedgwick \& Spiers). Setting up the videoconference was time intensive, taking from a few days to a few weeks to confirm bookings and then even after confirmation, one speaker cancelled on short notice because of higher priority meetings (Sedgwick $\&$ Spiers). The researcher had the same issues with trying to secure speakers that were difficult to connect with a classroom because of time conflicts. A suggestion made by an instructor is that the instructor could start with a list of people they already knew. This might make it easier to find someone who would be sure to make themselves available.

Except for the reports of various technical difficulties, all participants of the study gave positive feedback on most survey items. Before the study, the researcher had a vague idea that bringing guest speakers into the classroom via Internet videoconferencing would be an interesting new strategy to bring variety into the classroom. The researcher was pleasantly surprised to learn that this strategy did so much more than bring variety into the classroom. This strategy brought something different, yet positive, to each participant group. What do all of these findings mean for each participant population group? 
For instructors, the videoconference session represented an inexpensive teaching tool (at their disposal) to add to their students' educational experience in the classroom. Any competent instructor would want their students to have positive learning opportunities and experiences In this day and time with budget slashes and cut-backs, this strategy provides an inexpensive way to bring high value with diminishing cost per use that has been shown in this study to benefit students. The price of a web cam in a room that already has a computer and projection system brings an excellent return on its investment. Additionally, when an instructor uses technology in the classroom, the instructor appears more savvy and contemporary in the eyes of the student.

Internet videoconferencing can help maximize student learning opportunities to relate to people from the "real world." It can provide immediacy, immediate feedback and connection with an industry professional without that person needing to physically be in the classroom. The guest speaker can be almost 1,000 miles away as was industry professional B in the current study. In fact, the guest speaker can be almost anywhere in the world with Internet connectivity.

Instructors should start today to invite their industry contacts into their classroom via Internet videoconferencing. As instructors use this technological strategy, they will become more comfortable with its use. Skype is very easy to learn and use. Instructors can expand the use of this strategy, for example, to set up panel discussions or create additional best practices. With this strategy, instructors can have the best speakers that time can "provide." For students, the findings from this study represent the ability to get a look into the "real world." One of the guest speakers from this study said it precisely. "It is a gift to the students of the 'real world." The study is replete with numerous quotes on how much 
students benefited from and enjoyed this experience. Each participant group, including the students, rated the technology as much less than perfect. One student even said that she lost interest when the sound malfunctioned. Students understand, relate to, and respect technology. Because students understand technology, they know that it sometimes fails. They live with that and accept that. When their cell phones drop a call, they accept it and call the person back. They understand the benefits of the technology and that it outweighs most technology glitches. As was found in the study, even though the technology failed in various ways, the students still had overwhelming praise for the videoconferencing session. Students themselves answered the "so what" of the study and "why the study matters." They commented that the Internet videoconferencing should be implemented in every class. Other students commented that they learned that one should have integrity and they learned how important it is do your best. Students from one of the sessions were informed that sometimes people in the industry don't practice ethical traits. The students got to hear facts and advice before they go out into the "real world." Students learned what was important in keeping a job and what to expect. Students new to the experience should ask their instructors to invite industry professionals into the classroom via the Internet. Students could also introduce the practice of Internet videoconferencing by using Skype interviews in their various class projects, if applicable.

For the industry professional guest speakers, study findings show that participating in such an interaction with students represents a way to give back to an industry that has been good to them. All the speakers expressed the value that it had for them to speak to the students. It may be difficult to generalize these findings because of the small number of industry professional participants in this study, but all three participants, for whom there is no 
known connection, living in different cities, with different professions, felt the same way in that they enjoyed the interaction with the students.

It seems as if the industry professionals felt the desire to connect on a deeper level than simply that of a guest speaker; maybe they felt more like a mentor or role model, and as result, they shared more than just content, they shared some of the things they learned after years of working in the industry about dealing with people, about doing your best, about following your passion, etc. These are concepts and information that, no doubt, any instructor or school administrator would love to be passed on to their students. Industry professionals could contact various college and university fashion departments and offer instructors their own time to speak to students via Internet videoconferencing.

The contribution of this study will impact and add to four different areas: guest speakers, industry/school partnerships, Internet videoconferencing, and fashion design instruction.

The researcher changed as a result of conducting this study. There was not a realization, before the study, of how important these industry professionals were to students who many times have little clue about how it is "out there." The researcher also learned how important it was that seasoned professionals meet and have conversation with students before they go out into the work world in their chosen profession, after graduation. According to some of the student responses, students had never had a conversation with adults who currently work in the apparel industry. The researcher realized what a gift the students had been given and can be given as a result of this teaching strategy. One of the guest speakers who expressed that the researcher was giving a gift of the "real world" to the students, actually, was the one who had given that gift. 
If our schools are to be student learning outcome focused as many administrations are demanding, this is a viable strategy, not costly, and does not require much effort or labor on anyone's part. This brings the world into the classroom and the classroom into the world.

Research reveals the benefits of the classroom and industry partnership (Keitel, n.d.). Research has revealed the benefits of guest speakers in the classroom (Metrejean et al., 2002; Sniezek, 2005; WGBH Educational Foundation, 2006). This current study has further revealed the benefit of the industry/school partnership, the fact that the partnership is win-win, and that using Internet videoconferencing to bring the two partners together is considered informative, interesting, great, etc., in the eyes of the students This study has revealed benefits to all the participant groups including the instructors, students, and industry professional guest speakers. All three sets of participants are available and interested, a protocol has been designed, tested, and found successful, the equipment is inexpensive, learning Skype is easy (set up in less than 10 minutes), and many classrooms already have a computer with Internet connection, a projection unit and screen, and most instructors know someone in the industry. In this day and time of severe educational budget cutbacks and the goal of getting more value for the dollar, What could prevent instructors from giving this "gift" to their students?

\section{IMPLICATIONS}

Findings from this study provide evidence that using videoconferencing in the classroom is a win-win for the three stakeholders which include the students, the instructor, and the industry professional. For classroom practice, study findings suggest a need to have instructors and industry professionals knowledgeable about how to use Skype. This study, as 
an introductory study, did not provide a large enough sample from the instructor or industry professional population but responses from those two populations' participants strongly suggest their positive attitudes toward the videoconferencing experience.

All fashion design departments should consider having at least one smart classroom or access to a classroom with a computer, computer projection system, large screen, and high quality web cam where such videoconference sessions can be conducted. This equipment, if not already available in the school, could be obtained through grant funding. Many schools already have access to a smart classroom (with a computer, the Internet, and a projection system and large screen) and would only have to invest in a high quality web cam. Administrators or instructors can start by writing grant proposals and referencing the results from this study. Another suggestion would be for instructors to begin to develop contact lists of apparel industry professionals who might be interested in guest speaking with students on this platform. One way of getting the word out would be through advisory board meetings. Study results can be disseminated at those meetings and members can be given the opportunity to provide feedback on their interest in providing themselves as resources for the students. Many of the advisory board members may already use Skype. The advisory board meeting can be a place where they are shown the benefits of Internet videoconferencing (via a live Skype call during the meeting) and can get immediate training. Most advisory board meetings have in attendance both instructors and industry professionals. If information about the benefits of Internet videoconferencing cannot be distributed through advisory board meetings, workshops or meetings such as those used for new semester orientations can be used to inform and train instructors on the benefits and procedure for using Skype. School IT personnel should also be trained on how to troubleshoot possible Skype issues. 
There is an implied need to train industry professionals on using Skype in this student interaction. There are agencies, professional groups, trade associations etc., where apparel industry members congregate. These organizations can introduce its members to the benefits of this type of student interaction through their meetings. They can also use the meetings to provide training on how to use Skype.

Two other areas where this platform can be used are (a) instructors can conduct a class session even if, for some reason, the instructor cannot be in the classroom physically; and (b) potential industry employers might use Internet videoconferencing to screen or interview potential student interns. If an instructor is, for example, away at a conference, the administration would not have to hire a substitute. The instructor can make arrangements to hold her class session via Internet videoconference. Perhaps a teacher's assistant can make or respond to the connection between the instructor and the class on the day of the session. The instructor could participate with her classroom, even though many miles away.

The best time to bring this Internet videoconferencing event to the classroom is near the last third of the semester or term. For the protocol that was used in this session, this is a preferred time because students have had the time to become familiar with class content and the guest speaker would be reinforcing some of the things that have been taught by the instructor. The student would see the relevancy of the information being shared later, rather than earlier in the term. If the guest speaker is being used to introduce information that is to be built upon later in the term, then bringing in the speaker earlier, rather than later might be more beneficial. 


\section{STUDY LIMITATIONS}

The results of this study must be interpreted in light of its limitations. The limitations include a small sample size of instructors and apparel industry professionals.

The small number of instructors and apparel industry professionals make it difficult to generalize the findings to the population of fashion instructors and apparel industry professionals. A larger data set would lead to a more generalizable results.

\section{FUTURE RESEARCH}

The findings in this introductory study lay a foundation for future research since the findings from this preliminary studies were very positive. There are six suggestions for future studies presented below.

The first suggestion for further study would be to duplicate this study with a larger sample, using more instructors and industry professionals which, concurrently, would raise the number of student participants. The current sample size does not allow for generalizability to the population of instructors and industry professionals.

The second suggestion is to research the equipment used for the technology. The study revealed mostly negative responses to issues concerning the technology (web cam) used in the study. All three schools reported negative technology issues. A study that compares web cams, school bandwidths, and computer maximum capabilities on smooth audio and visual transmission in the university and college classroom could be researched with the goal of providing equipment recommendations to address study issues with the technology.

Another important issue to consider for future study is developing an industry professional contact list. One of the issues that the researcher encountered was finding 
enough guest speakers that were available to speak to the classroom during normal class days and times. Many organizations have industry professionals who could be contacted to find out if they would be willing to be considered as guest speakers via Skype to various classrooms. The results of the study could provide a list of interested industry professionals who would be available and interested in speaking to students. Along with this suggestion, an organization could be developed that would set up the appointments between the school/instructor and the industry professional so that the instructor would have a ready base of guest speakers.

The fourth suggestion for future research can be conducted to discover how this type of interaction could be used for additional student learning opportunities. For example, one student participant suggested using this platform to bring an industry professional panel discussion to the classroom. Having a myriad of suggestions on expanded use of this platform could provide additional incentive for instructors to use this technology to benefit their students.

The fifth suggestion for future research would be to duplicate this study using all men as the industry professional guest speakers. In this study, all the guest speakers were women. The findings in that new study could be compared with the findings from this study to discover if the gender of the guest speaker makes a difference in student and instructor ratings and perceptions.

Finally, the sixth suggestion is that this study could be duplicated in 5 years to see how students respond to the same Likert scale statements. In this study, many students were awed by how technology could be used to bring guest speakers into the classroom. Many of the students in the study had not used a web cam or experienced a videoconference. In 
5 years, when this technology is commonplace and students possibly will have had several experiences with Internet videoconferencing, will student responses be the same?

\section{CONCLusion}

This mixed-method multiple case study investigated the efficacy, benefits, and student perceptions of using videoconferencing with Internet software and a web camera to connect college and university fashion students with apparel industry professionals. Literature on guest speakers showed that the industry professional could benefit as a guest speaker by being connected to and aware of what was happening in the classroom as well as being able to "give back." The instructor/students could benefit by having an "inside look" into the business world and students could benefit by having a head start with networking and contacts for future employment. This study agreed with previous related studies and provided additional evidence of the benefits of the videoconferencing experience between the classroom and the apparel industry professional guest speaker. The study showed that instructor has the additional teaching tool of the Internet and a web cam to facilitate the connection between the school curriculum and the industry in connecting theory with practice.

This study provided evidence that students and the instructors benefit from the experience. Instructors' student learning objectives can be met and students can see a window into their future, learn about career options, and get advice from industry professionals. The guest speaker also benefited by having the opportunity to encourage the students and provide a real world perspective. 
Implications suggest that colleges and universities should have smart classrooms and web cams, instructors and industry professionals should be informed about and trained on how to use Skype, and contact lists need to be developed to provide a reservoir of potential guest speakers.

Further research is needed to establish generalizability across all populations, to determine equipment (web cam) offerings and limitations, to develop industry professionals contact lists, and to provide additional learning opportunities for using Skype.

This study contributes to the body of research in this field by (a) establishing a method by which schools can be connected to apparel industry professionals, and by (b) documenting the benefits and challenges of using Internet videoconferencing between university and college fashion students and apparel industry professionals.

In conclusion, for the price of a web cam and equipment already in most classrooms, an important teaching tool is available. Internet videoconferencing can be used by instructors to bring industry professional guest speakers, from all over the world, into the classroom. These guest speakers can benefit students and assist the instructor in bringing real world content, context, and perspective. 


\section{REFERENCES}

Adams, J. (n.d.). Projects, placements and participation: The art industry internship program. Retrieved March 28, 2008, from http://www.acuads.com.au/conf2006/ papers_refereed/adams.pdf

AT\&T Knowledge Network Explorer. (2008). Videoconferencing glossary. Retrieved May 13, 2009, from http://www.kn.pacbell.com/wired/vidconf/glossary.html

Balint, K. (2007). Shall we Skype? Network Journal, 15(1), 42. Retrieved February 7, 2008, from Ethnic NewsWatch (ENW) database (Document ID: 1371145351).

Barnes, B., Morley J., \& Sayers, S. (Eds.). (2002). Issues in design and technology teaching. New York: Routledge Falmer.

Bengtson, S. (2006). Universities, companies benefit from partnerships. San Diego Business Journal, 27(22), 19. Retrieved March 27, 2008, from ProQuest Newsstand database (Document ID: 1049826091).

Blais, R., \& Adelson, G. (1998). Partnerships in education: Project Lead the Way models a program for changing technology education. Tech Directions, 58(4), 40-43.

Cockrell, E. (2002). Prenursing students' perceptions of the nursing profession. Unpublished master's thesis, Louisiana State University. Retrieved July 25, 2007, from http://etd.lsu.edu/docs/available/etd-0612102-103031/unrestricted/Cockrell_thesis.pdf

Cogburn, D. L. (n.d.). Globalization, knowledge, education and training in the information age. Retrieved February 20, 2008, from http://www.unesco.org/webworld/ infoethics_2/eng/papers/paper_23.rtf

Cotlar, M., \& Shimabukuro, J. N. (1993). Stimulating learning with electronic guest lecturing. Interpersonal Computing and Technology: An Electronic Journal for the 21st Century, 1(1). Retrieved November 15, 2006, from http://www. emoderators.com/ipct-j/1993/n1/cotlar.tx

Coventry, L. (n.d.). Conferencing in higher education. Retrieved February 24, 2008, from http://www.agocg.ac.uk/reports/mmedia/video3/video3.pdf

Creswell, J. (1998). Qualitative inquiry and research design: Choosing among five traditions. Thousand Oaks, CA: Sage Publications. 
Daley, L., Spalla, T., Arndt, M., \& Warnes, A. (2008). Videoconferencing and web-based conferencing to enhance learning communities. Journal of Nursing Education, 47(2), 78-81. Retrieved January 30, 2010, from Education Module (Document ID: 1419585451).

Dedmond, R. M. (1991). Establishing, coordinating school-community partnerships. National Association of Secondary School Principals. NASSP Bulletin, 75(534), 28. Retrieved March 27, 2008, from Research Library Core (Document ID: 31 15147).

Garfinkel, S. (2005). Skype security overview: VoIP and Skype security. Retrieved February 19, 2008, from http://www.cs.huji.ac.il/labs/danss/p2p/ resources/Skype-security.pdf

Guha, S., Daswani, N., \& Jain, R. (2006). An experimental study of the Skype peer-to-peer VoIP system. Retrieved February 19, 2008, from http:/www.iptps.org/papers-2006/ Guha-skype06.pdf

Hirsch, D. (1992). The schools/business partnership. Organisation for Economic Cooperation and Development. The OECD Observer, 174, 16. Retrieved March 27, 2008, from ABI/INFORM Global database (Document ID: 915236).

Holtz, S. (2005). Cutting the cost of calls with Skype. Strategic Communication Management, 10(1), 3. Retrieved February 7, 2008, from ABI/INFORM Global (Document ID: 947902151).

Inaba, A., \& Mizoguchi, R. (2004). Learner's role and predictable educational benefits in collaborative learning. Proceedings of International Conference on Intelligent Tutoring Systems, Alagoas, pp. 285-294. Retrieved February 6, 2010, from http://www.ei.sanken.osaka-u.ac.jp/pub/ina/ina_its04.pdf

International Textile and Apparel Association. (n.d.). The Global Organization of Textile and Apparel Scholars: About ITAA. Retrieved February 26, 2008 from http://www. itaaonline.org/www.default/index.cfm/about-itaa/

Isaac, S., \& Michael, W. (1997). Handbook in research and evaluation for educational and the behavioral sciences (3rd ed.). San Diego: EDITS.

Isaacs, E. A., \& Tang, J. C. (1993). What video can and can't do for collaboration: A case study. In MULTIMEDIA '93: Proceedings of the first ACM International Conference on Multimedia, pp. 199-206. New York: ACM Press. Retrieved July 29, 2007, from http://www.izix.com/pubs/Isaacs-VideoCollaboration-mm93.pdf

Julius, D. (1997). Globalization and stakeholder conflicts: A corporate perspective. International Affairs, 73(3), 453-468. 
Keitel, R. (n.d.). A proposed model of higher education institution-Call center industry partnership. Retrieved March 22, 2008, from http://www.unescobkk.org/fileadmin/ user_upload/apeid/Conference/1 1 thConference/papers/3E1_Robert_Keitel.pdf

Klemm, E. B., \& Tuthill, G. (2003). Virtual field trips: Best practices. International Journal of Instructional Media, 30(2), 177-193.

Kumari, D. S. (2001). Connecting graduate students to virtual guests through asynchronous discussions: An analysis of an experience. Journal for Asynchronous Learning Networks, 5(2). Retrieved November 15, 2006, from http://www.sloan-c.org/ publications/JALN/v5n2/v5n2_kumari.asp!

La Pelle, N. (2004). Simplifying qualitative data analysis, using general purpose software tools. Field Methods, 16(1), 85-108. Retrieved January 30, 2010, from http://club.fom.ru/books/Pelle04_1.pdf (doi: 10.1177/1525822X03259227)

Leedy, P., \& Ormrod, J. (2001). Practical research: Planning and design (7th ed.). Columbus, OH: Merrill Prentice Hall.

Lim, J., \& Freed, S. (2009). We have the videoconference equipment installed, now what? The Qualitative Report, 14(3), 433-453. Retrieved January 30, 2010, from Social Science Module (Document ID: 1913678211).

Lincoln, Y., \& Guba, E. (1985). Naturalistic inquiry. Beverly Hills: Sage Publications. Chapter 5-Standards for judging naturalistic inquiry. Retrieved March 30, 2008, from http://webpub.byu.net/ddw/qualitativebook/pdf/chapter5.pdf

Medlin, B., Schneberger, S., \& Hunsinger, D. S. (2007). Perceived technical information technology skill demands versus advertised skill demands: An empirical study. Journal of Information Technology Management, 18(3-4), 14-23.

Melville, B., \& Hawke, G. (2002). School/industry links and partnerships: A review. Working paper. Retrieved March 21, 2008, from http://www.oval.uts.edu.au/ working_papers/2001WP/0102melville.pdf

Metrejean, C., Pittman, J., \& Zarzeski, M. (2002). Guest speakers: Reflections on the role of accountants in the classroom. Accounting Education, 11(4), 347-364. Retrieved March 21, 2008. doi:10.1080/0963928021000031466

Michielli, M. (2000). Roboitics: Building bridges between industry and education. Tech Directions, 60(4), 16-19. Retrieved March 27, 2008, from Wilson Web

Mikulas, W. (n.d.). Behavior modification. Retrieved November 28, 2006, from http://www.uwf.edu/psych/bmikulas/Webpage/behavior/chaptereight.htm 
Pachnowski, L. M. (2002). Virtual field trips through videoconferencing. Learning \& Leading with Technology, 29(6), 10-13. Retrieved April 19, 2009, from http://www. iste.org/L\&L/archive

Pajares, F. (2004). Albert Bandura: Biographical sketch. Retrieved November 28, 2006, from http://des.emory.edu/mfp/bandurabio.html

Paprika, Z., \& Ozcelik, H. (2007). Utilizing videoconferencing to develop emotional awareness in cross-cultural communication. Retrieved January 30, 2010, from http://edok.lib.unicorvinus.hu/116/01/Paprika78.pdf

Penn State. (n.d.). Bringing guest speakers into your class using Adobe Connect (formerly Breeze Meeting). Retrieved July 29, 2007, from http://tlt.its.psu.edu/breeze/ TipsGuestSpeakers.htm

Petersen, R. (2000). "Real World" connections through videoconferencing-We're closer than you think! TechTrends, 44(6). Retrieved January, 2010. doi: 10.1007/ BF02763308

Roberts, L. (2004). The history of video conferencing-Moving ahead at the speed. Retrieved January 30, 2010, from http://www.articleslash.net/article_23175.pdf

Rowland, J. (2007). A guest lecturing program to improve students' applied learning. Reputation, responsibility, relevance. Conference proceedings, Anzmac 2007, University of Otago, Dunedin, New Zealand. Retrieved February 6, 2010, from NANZMAD2007/listByAuthor.html\#R

Ryobe, I. (2008). The effects of Skype-based video chats with volunteer Filipino English teachers (II): Discovering the superiority of videochat. Retrieved January 30, 2010, from http://www.j-let.org/ wcf/proceedings/d-088.pdf

Sedgwick, X., \& Spiers, J. (2009). The use of videoconferencing as a medium for the qualitative interview. Retrieved February 1, 2010, from http://creativecommons.org/ licenses/by/2.0

Sim, S. E. (1998). Characterizing how software maintainers work: Culture and habits. Proceedings of the workshop on empirical studies of software maintenance, 11-12. Retrieved April 19, 2010, from http://www.ics.uci.edu/ ses/papers/wess98.txt

Sniezek, T. (2005). Avoiding the pitfalls of the invited speaker. Exchanges: The Online Journal of Teaching and Learning in the CSU. Retrieved November 29, 2006, from http://www.exchangesjournal.org 
Suduc, A., Bizoi, M., \& Filip, F. (2009). Exploring multimeda web conferencing. Informatica Economica, 13(3), 5017. Retrieved January 20, 2010, from ABI/INFORMGlobal (Document ID 1914675911).

Tabata, L., \& Johnsrud, L. (2008). The impact of faculty attitudes toward technology, distance education, and innovation. Research in Higher Education, 49(7), 625-646. Retrieved January 30, 2010, from Education Module. (Document ID 1896807941).

Threlkeld, H. (1935). The educational and vocational plans of college seniors. New York: Teachers College, Columbia University.

Varvel, V. (2001). Guest lecturers in the online environment (Part 2 of 2). Illinois Online Network: Pointers and Clickers. Retrieved November 28, 2006, from http://www.ion.uillinois.edu/resources/pointersclickers/2001_09/index.asp

Video Conferencing History. (n.d.). Retrieved February 15, 2007, from http:/www. wiredred.com/video-conferencing-history.html

Wang, Y. (2004). Supporting synchronous distance language learning with desktop videoconferencing. Language Learning \& Technology, 8(3), 90-121. Retrieved November 22, 2006, from http://llt.msu.edu/vol8num3/wang/default.ht

Weber, L., \& and Lieberman, J. (n.d.). Strategies for effective use of chat: When, why, and how to make it work. Retrieved February 20, 2008, from http://168.144.129.112/ Articles/Strategies\%20for\%20Effective\%20Use\%20of\%20Chat--When, $\% 20$ Why, $\% 2$ 0and\%20How\%20to\%20Make\%20It\%20Work.rtf

WGBH Educational Foundation. (2006). Learning in the community: Developing learning experiences. Retrieved November 29, 2006, from http://www.league.org/ gettingresults/web/module4/learning/developing.html

Zarotsky, V., \& Jaresko, S. (2000). Technology in education-Where do we go from here? Journal of Pharmacy Practice, 13(5), 373-381. doi: 10.1106/ KGPB-NN3A-7FPG-Y6JD

Zerr, D., \& Pulcher, K. (2008). Using interactive video technology in nursing education: A pilot study. Journal of Nursing Education, 47(2), 87-91. Retrieved January 30, 2010, from Education Module (Document ID: 1419585441). 
APPENDIX A

INSTRUCTOR INVITATION TO PARTICIPATE IN RESEARCH STUDY 


\section{INSTRUCTOR INVITATION TO PARTICIPATE IN RESEARCH STUDY}

I would like to invite you to participate in a research study for a doctoral dissertation conducted by myself, Vera Bruce Ashley, a student doctoral candidate in the Joint Educational Doctorate Program at the University at San Diego and San Diego State University. The title of the dissertation is Using Internet Videoconferencing to Connect Fashion Design Students to Apparel Industry Firms.

You were identified as a possible participant in the study because you teach classes in a

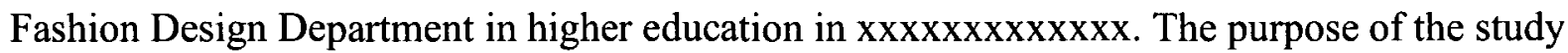
is to explore the benefits, effectiveness, perceptions and practicality of using Internet videoconferencing software and a web cam to connect higher education (college and university) adult (18 and over) fashion students with apparel industry firms. This study will examine these variables from the perspective of instructors, students and apparel firm representatives. There are six study research questions:

1. What are the expectations of the student, instructor and fashion industry professional before engaging in the Internet videoconferencing session?

2. How do students perceive the experience of interacting with the fashion industry professional who visits the classroom via Internet videoconferencing?

(a) Were student expectations met after the videoconferencing session?

(b) How do the students rate the fashion industry professional's personality traits?

(c) What are the students' perception of the fashion industry professional's effectiveness and content knowledge?

(d) How did technology impact the experience for the students?

(e) What was the students' overall perception of the experience? 
3. Is there a difference in the perception of the videoconference session between schools or based on the guest speaker?

4. How do fashion instructors whose students are visited by and interact with fashion industry professionals via Internet videoconferencing perceive the experience?

(a) Were instructor's expectations met?

(b) According to the instructors, what session objectives were met?

(c) How did instructors rate the technology of the session?

(d) How did instructors rate student benefits of the session?

(e) How did instructors rate the feasibility of the Internet session?

(f) What was the instructors' overall perception of the experience?

5. How do fashion industry professionals who visit and interact with fashion students via Internet videoconferencing perceive the experience?

(a) How did apparel industry professionals feel that they benefited the students as a result of the videoconference session?

(b) What was the apparel industry professional's overall perception of the experience?

(c) What factors motivate the fashion industry professional to participate in the Internet videoconferencing session?

(d) What factors hinder the fashion industry professional in engaging in the Internet videoconferencing interaction with the students?

6. What are the hindrances to the process of setting up Internet videoconferencing in the classroom with higher education classes? 
The Student Learning Objectives for this exercise are:

\section{Career Awareness:}

The student will be able to describe the duties of an employment position in the apparel industry.

2. Broader Knowledge:

The student will be able to relate the theory they are learning in the classroom to real life application.

\section{Personal Development:}

The student will be able to describe the attitudes necessary for career success. Study participants include three instructors who teach fashion design classes and his/her students, and three apparel firms representatives. This is an exploratory three case study. The study is planned for the fall 2009 semester. Criteria for inclusion in the study is that the fashion design instructor must be teaching a fashion design class for the fall semester and have access to a computer, the internet and a projection system (i.e. smart classroom) with the ability to connect a web cam (which will be provided, if necessary, without cost to you). The instructor also must have the ability to download the web cam software and videoconferencing software onto the class computer and have access to an IT department or help desk employee during the videoconferencing session to help troubleshoot any problems during the videoconferencing session.

Your participation will require the following steps/interactions with approximate time line and time commitments:

1. Completing and returning a Consent form (10 minutes)

2. Completing a Pre-Survey (10 minutes) 
3. Responding to an e-mail from the researcher informing you who is to be the apparel industry partner ( 3 minutes)

4. Informing your students of the visit by the Internet guest speaker at least 2 weeks in advance (3minutes)

5. Downloading Skype and webcam software (15 minutes)

6. Appointment to meet with researcher for SKYPE test connection in the classroom. Researcher will travel to school site (15 minutes)

7. Collecting and sending (via e-mail) student generated questions to researcher who will send the questions to the guest speaker. (15 minutes)

8. Verbally reminding students of the upcoming videoconferencing session (5 minutes)

9. Videoconferencing Session (40 minutes)

10. Post session survey (via paper survey questionnaire) (10 minutes)

11. Follow-up interview-(via e-mail) (10 minutes)

Approximate total time commitment $2 \frac{1}{4}$ hours.

Following is my abstract:

The purpose of the proposed study is to explore the benefits, effectiveness, and student perceptions of using Internet videoconferencing software and a web camera to connect higher education (college and university) fashion students with apparel industry firms. This is a multiple (three) case qualitative study using a set of two partner participants with the school/student group as the school partner and the apparel industry firm as the industry partner. Study focus will gather data to discover instructor, student and industry firm perceptions and attitudes about the Internet videoconferencing experience. Data collection methods include surveys, interviews and researcher journal documentation. Qualitative data analysis will be employed to reveal and compare and contrast findings between and among participant cases. This exploratory study hopes to reveal the nature of the developed process of using Internet videoconferencing to connect fashion students with the apparel industry. This study also hopes to develop early generalizations within real world contexts and to provide a means by which Internet videoconferencing between schools and industry partners 
can be evaluated for effectiveness. Implications for classroom practice and suggestions for further research will be discussed.

If you are interested in participating in my study, please respond and I will send you a consent form to complete and return to me. This experience can serve your classroom by providing a guest speaker for one of your courses. If you need more information, please feel free to

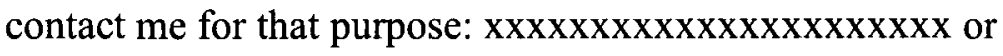

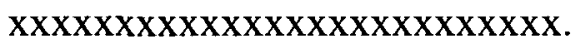

Thank you very much.

Vera Bruce Ashley

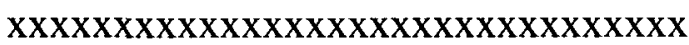

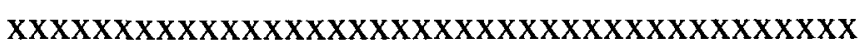

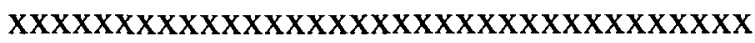

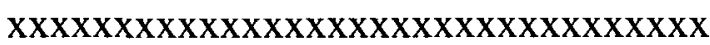




\section{APPENDIX B}

\section{INDUSTRY PROFESSIONAL INVITATION TO}

PARTICIPATE IN RESEARCH STUDY 
Industry Professional Invitation to Participate in Research Study

$\operatorname{xxxxx}$

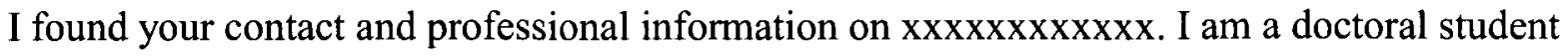
at the University of San Diego/San Diego State University. xxxxxxxxxxxxxxxxxxxxxxxxxx. My dissertation topic is using Internet videoconferencing to connect fashion students with fashion industry professionals. The participant sets of my study are the college instructor and his/her students and a fashion industry professional. Currently, I have a university (in the

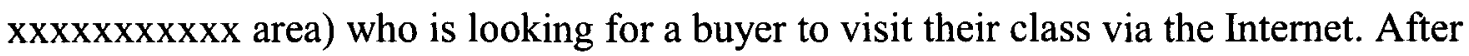
viewing your background, I felt that you might be an fascinating guest speaker for this classroom (via the internet). You would be using SKYPE to connect with the classroom.

Thank you for your preliminary interest. This class is called "xxxxxxxxxxxxxx" and would

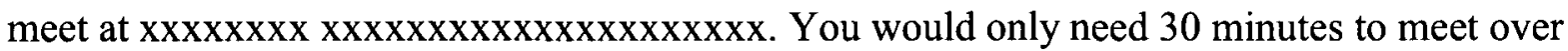
SKYPE that day to answer student generated questions that you would receive in advance.

If you are interested and available, please let me know and I will send you additional information including my research questions and other "paperwork." The approximate time commitment I would need from you for this entire project is less than $1 \frac{1}{2}$ hours.

I look forward to hearing from you. Thank you. 
APPENDIX C

INSTRUCTOR PRE-SURVEY 


\section{Instructor Pre-Survey}

1. What describes your current position? Check all that apply.
- Classroom Instructor-Full-time
- Classroom Instructor-Part-time
- Department Administrator
Other (please specify)

2. What is your title?

3. What is your highest completed level of education?
_ High School or GED
- Associate's degree
- Bachelor's degree
- Master's degree
- Doctorate
Other (please specify)

4. Which category is your school?
- Community College
— Four-Year University
- Private College
Other (please specify)

5. Are you teaching a fashion class and have access to a computer, the internet and a projection system with the ability to connect a web cam and download web cam and SKYPE software?
Yes
$-\quad$ No
Other (please specify)

6. Do you already have a web cam, or do you need one provided to you? Please check the statement that specifies whether you are using a PC or a MAC.

- Yes, I need a web cam provided to me and I am using a PC

— Yes, I need a web cam provided to me and I am using a MAC 
No, I do not need a web cam provided to me and I am using a PC

- No, I do not need a web cam provided to me and I am using a MAC

If you need a web cam provided for you, please provide an address where you want the web cam to be sent.

7. How long have you taught fashion courses?

_ Less than a year

- 1 to 3 years

- $\quad 4$ to 8 years

- 9 to 14 years

- 15 years and over

Other (please specify)

8. How many times in the past five years have you had a guest speaker come to your classroom?

$\begin{array}{ll}-\quad & \text { Never } \\ -\quad & 1-5 \text { times } \\ -\quad & 6 \text { to } 10 \text { times } \\ -\quad & 11 \text { to } 19 \text { times } \\ -\quad & 20 \text { or more times } \\ & \text { Other (please specify) }\end{array}$

9. Have all your guest speakers been face to face meetings?

Yes
$-\quad$ No
Other

10. What information technologies do you currently use in your teaching and class presentations?

Email
$-\quad$ PowerPoint 
Videoconferencing

Other (please specify)

11. Have you ever taught a distance education course of a course over the Internet? Please also include hybrid courses.

Yes
$-\quad$ No

If the answer is yes to the above question, What course(s) did you teach? What classroom management system did you use?

12. Have you ever used Internet videoconferencing software including Instant Messaging and SKYPE for personal or social purposes?

Yes
$-\quad$ No

If yes, what software did you use and how many times have you used it?

13. Have you ever used Internet videoconferencing software including Instant Messaging and SKYPE for teaching purposes?

Yes
$-\quad$ No

If yes, what software was used? How many times have you used it? 
14. What are your expectations about the Internet videoconferencing session?

15. Which of the following student learning objectives do you feel can be met through Internet videoconferencing? Check all that apply.

Career Awareness: The student will be able to describe the duties of an employment position in the apparel industry.

Broader Knowledge: The student will be able to relate the theory they are learning in the classroom to real life application.

Personal Development: The student will be able to describe the attitudes necessary for career success.

Other (please specify)

16. Please rate your presentation expectations of the videoconferencing session in the following areas.

Strongly

Disagree Disagree Undecided Agree Agree

a) I believe students will learn about real world relationships

b) I believe that the guest speaker will be engaging and interesting.

c) I believe the guest speaker will promote his company/firm.

Other (please specify)

17. In what career area(s) or course(s) would you like to have a guest speaker presentation of about 30 minutes? Please be specific.

Garment or accessory buying

Fashion designer
Production manager
Textile designer 
Other (please specify)

18. Please list the course title, day and time that you would like to have the guest speaker in your classroom via the Internet. Please list an email by which the researcher can contact you.

19. How many students are enrolled in the above class?

$$
\begin{array}{ll}
- & \text { Under } 10 \\
-\quad & 11-20 \\
- & 21-30 \\
- & 31-40 \\
- & \text { Over } 41
\end{array}
$$

20. Please use this area for any comments, concerns or questions you have about the videoconferencing session. 
APPENDIX D

INSTRUCTOR POST-SURVEY 
Using Internet Videoconferencing to Connect Fashion Students to Fashion Industry Professionals

Instructor's Assessment of Videoconferencing Experience

Post Session Questionnaire

Name of Class

Number of students enrolled Number of students present today

Today's Date

Please respond to the following questions by circling your response or filling in the blanks .

\section{Were your presentation expectations met?}

\begin{tabular}{|l|c|c|c|c|c|}
\hline & $\begin{array}{c}\text { Strongly } \\
\text { disagree }\end{array}$ & Disagree & Undecided & Agree & $\begin{array}{c}\text { Strongly } \\
\text { agree }\end{array}$ \\
\hline $\begin{array}{l}\text { 1. The students learned about real } \\
\text { world relationships }\end{array}$ & 1 & 2 & 3 & 4 & 5 \\
\hline $\begin{array}{l}\text { 2. The guest speaker was } \\
\text { engaging and interesting }\end{array}$ & 1 & 2 & 3 & 4 & 5 \\
\hline $\begin{array}{l}\text { 3. The guest speaker promoted } \\
\text { his company/firm }\end{array}$ & & & & & \\
\hline 4. Other: Please list & & & & & \\
\hline
\end{tabular}


What were the guest speaker's personality traits?

\begin{tabular}{|c|c|c|c|c|c|}
\hline & $\begin{array}{l}\text { Strongly } \\
\text { disagree }\end{array}$ & Disagree & Undecided & Agree & $\begin{array}{l}\text { Strongly } \\
\text { agree }\end{array}$ \\
\hline 5. The guest speaker was pleasant & 1 & 2 & 3 & 4 & 5 \\
\hline $\begin{array}{l}\text { 6. The guest speaker was creative } \\
\text { and imaginative }\end{array}$ & 1 & 2 & 3 & 4 & 5 \\
\hline $\begin{array}{l}\text { 7. The guest speaker was self- } \\
\text { disciplined and conscientious }\end{array}$ & 1 & 2 & 3 & 4 & 5 \\
\hline $\begin{array}{l}\text { 8. The guest speaker was } \\
\text { energetic, positive and } \\
\text { enthusiastic }\end{array}$ & 1 & 2 & 3 & 4 & 5 \\
\hline $\begin{array}{l}\text { 9. The guest speaker was } \\
\text { compassionate and friendly }\end{array}$ & 1 & 2 & 3 & 4 & 5 \\
\hline $\begin{array}{l}10 . \text { The guest speaker was calm } \\
\text { and relaxed }\end{array}$ & 1 & 2 & 3 & 4 & 5 \\
\hline $\begin{array}{l}\text { 11. The guest speaker was } \\
\text { humorous }\end{array}$ & 1 & 2 & 3 & 4 & 5 \\
\hline 12. Other: Please list & & & & & \\
\hline
\end{tabular}


Teaching presentation: Content and effectiveness

\begin{tabular}{|c|c|c|c|c|c|}
\hline & $\begin{array}{l}\text { Strongly } \\
\text { disagree }\end{array}$ & Disagree & Undecided & Agree & $\begin{array}{l}\text { Strongly } \\
\text { agree }\end{array}$ \\
\hline $\begin{array}{l}\text { 13. The guest speaker dressed } \\
\text { professionally }\end{array}$ & 1 & 2 & 3 & 4 & 5 \\
\hline $\begin{array}{l}\text { 14. The guest speaker was well } \\
\text { prepared }\end{array}$ & 1 & 2 & 3 & 4 & 5 \\
\hline $\begin{array}{l}\text { 15. The guest speaker was } \\
\text { organized }\end{array}$ & 1 & 2 & 3 & 4 & 5 \\
\hline $\begin{array}{l}\text { 16. The guest speaker obviously } \\
\text { knew her material }\end{array}$ & 1 & 2 & 3 & 4 & 5 \\
\hline $\begin{array}{l}\text { 17. The guest speaker was } \\
\text { intelligent }\end{array}$ & 1 & 2 & 3 & 4 & 5 \\
\hline $\begin{array}{l}\text { 18. The guest speaker captured } \\
\text { and held my attention }\end{array}$ & 1 & 2 & 3 & 4 & 5 \\
\hline $\begin{array}{l}\text { 19. The presentation was thought } \\
\text { provoking }\end{array}$ & 1 & 2 & 3 & 4 & 5 \\
\hline $\begin{array}{l}\text { 20. The guest speaker } \\
\text { communicated at a level } \\
\text { conducive to my students' } \\
\text { learning }\end{array}$ & 1 & 2 & 3 & 4 & 5 \\
\hline $\begin{array}{l}21 \text {. The guest speaker was } \\
\text { relaxed }\end{array}$ & 1 & 2 & 3 & 4 & 5 \\
\hline $\begin{array}{l}\text { 22. The guest speaker should be } \\
\text { invited back to speak to another } \\
\text { class }\end{array}$ & 1 & 2 & 3 & 4 & 5 \\
\hline $\begin{array}{l}\text { 23. I would like to have more } \\
\text { sessions like this }\end{array}$ & 1 & 2 & 3 & 4 & 5 \\
\hline $\begin{array}{l}\text { 24. The guest speaker was a good } \\
\text { role model for my students }\end{array}$ & 1 & 2 & 3 & 4 & 5 \\
\hline $\begin{array}{l}25 \text {. The guest speaker provided } \\
\text { career options for my students }\end{array}$ & 1 & 2 & 3 & 4 & 5 \\
\hline $\begin{array}{l}\text { 26. Overall, the presentation was } \\
\text { a worthwhile, educational } \\
\text { experience }\end{array}$ & 1 & 2 & 3 & 4 & 5 \\
\hline
\end{tabular}


Technology

\begin{tabular}{|l|c|c|c|c|c|}
\hline & $\begin{array}{c}\text { Strongly } \\
\text { disagree }\end{array}$ & Disagree & Undecided & Agree & $\begin{array}{c}\text { Strongly } \\
\text { agree }\end{array}$ \\
\hline $\begin{array}{l}\text { 27. The quality of the audio was } \\
\text { excellent }\end{array}$ & 1 & 2 & 3 & 4 & 5 \\
\hline $\begin{array}{l}\text { 28. The quality of the video was } \\
\text { excellent }\end{array}$ & 1 & 2 & 3 & 4 & 5 \\
\hline $\begin{array}{l}\text { 29. The projection screen was } \\
\text { large enough to see the guest } \\
\text { speaker comfortably }\end{array}$ & 1 & 2 & 3 & 4 & 5 \\
\hline $\begin{array}{l}\text { 30. During the session, the } \\
\text { technology functioned properly }\end{array}$ & 1 & 2 & 3 & 4 & 5 \\
\hline
\end{tabular}


Session Objectives

\begin{tabular}{|c|c|c|c|c|c|}
\hline & $\begin{array}{l}\text { Strongly } \\
\text { disagree }\end{array}$ & Disagree & Undecided & Agree & $\begin{array}{l}\text { Strongly } \\
\text { agree }\end{array}$ \\
\hline $\begin{array}{l}\text { 31. This session motivated my } \\
\text { students }\end{array}$ & 1 & 2 & 3 & 4 & 5 \\
\hline $\begin{array}{l}\text { 32. This session entertained my } \\
\text { students }\end{array}$ & 1 & 2 & 3 & 4 & 5 \\
\hline $\begin{array}{l}\text { 33. This session informed my } \\
\text { students }\end{array}$ & 1 & 2 & 3 & 4 & 5 \\
\hline $\begin{array}{l}\text { 34. As a result of this session, I } \\
\text { feel that the students will be able } \\
\text { to describe the duties of an } \\
\text { employment position in the } \\
\text { apparel industry }\end{array}$ & 1 & 2 & 3 & 4 & 5 \\
\hline $\begin{array}{l}35 . \text { As a result of this session, I } \\
\text { feel that the students will be able } \\
\text { to relate the theory they are } \\
\text { learning in the classroom to real } \\
\text { life application }\end{array}$ & 1 & 2 & 4 & 4 & 5 \\
\hline $\begin{array}{l}\text { 36. As a result of this session, I } \\
\text { feel that the students will be able } \\
\text { to describe the attitudes } \\
\text { necessary for career success }\end{array}$ & 1 & 2 & 3 & 4 & 5 \\
\hline $\begin{array}{l}\text { 37. This session represents a } \\
\text { practical and inexpensive way to } \\
\text { bring in guest speakers to my } \\
\text { classroom }\end{array}$ & 1 & 2 & 3 & 4 & 5 \\
\hline $\begin{array}{l}\text { 38. I would like to bring guest } \\
\text { speakers into my classroom via } \\
\text { Internet videoconferencing }\end{array}$ & 1 & 2 & 3 & 4 & 5 \\
\hline $\begin{array}{l}\text { 39. I plan to bring guest speakers } \\
\text { into my classroom via Internet } \\
\text { videoconferencing }\end{array}$ & 1 & 2 & 3 & 4 & 5 \\
\hline $\begin{array}{l}\text { 40. It would be easy for me to set } \\
\text { up and execute a video- } \\
\text { conferencing session like this one } \\
\text { without the help of the researcher }\end{array}$ & 1 & 2 & 3 & 4 & 5 \\
\hline $\begin{array}{l}41 \text {. It would be easy for me to } \\
\text { find guest speakers who would } \\
\text { visit my students via Internet } \\
\text { videoconferencing }\end{array}$ & 1 & 2 & 3 & 4 & 5 \\
\hline
\end{tabular}


Feasibility

\section{Additional Questions}

42. What was the part you liked best about using videoconferencing in this session?

43. What was the part you liked least about using videoconferencing in this session?

44. In one word, how would you describe this videoconferencing experience?

45. How would yo go about finding guest speakers to visit your classroom via Internet videoconferencing?

46. Please share other issues, suggestions, questions or thoughts about this experience with videoconferencing.

47. How else could you use videoconferencing to benefit our students?

Thank you for completing this survey. 
APPENDIX E

STUDENT PRE-SURVEY 
Using Internet Videoconferencing to Connect Fashion Students to Apparel Industry Professionals

\section{$\underline{\text { Student }} \underline{\text { Pre-Session Survey }}$}

What are your presentation expectations before the session?

\begin{tabular}{|l|c|c|c|c|c|}
\hline & $\begin{array}{c}\text { Strongly } \\
\text { disagree }\end{array}$ & Disagree & Undecided & Agree & $\begin{array}{c}\text { Strongly } \\
\text { agree }\end{array}$ \\
\hline $\begin{array}{l}\text { 1. I think I will learn about real } \\
\text { world relationships }\end{array}$ & 1 & 2 & 3 & 4 & 5 \\
\hline $\begin{array}{l}\text { 2. I think that the guest speaker } \\
\text { will be engaging and interesting }\end{array}$ & 1 & 2 & 3 & 4 & 5 \\
\hline $\begin{array}{l}\text { 3. I think that the guest speaker } \\
\text { will promote his company/firm }\end{array}$ & 1 & 2 & 3 & 4 & 5 \\
\hline 4. What is the most important thing you would like to gain out of this experience? \\
\hline
\end{tabular}




\section{APPENDIX F}

STUDENT POST-SESSION SURVEY 
Write the number on your ticket here

\section{Student Survey \\ Student Assessment of Post-Videoconferencing Experience}

What were your experiences after the session?

\begin{tabular}{|l|c|c|c|c|c|}
\hline & $\begin{array}{c}\text { Strongly } \\
\text { disagree }\end{array}$ & Disagree & Undecided & Agree & $\begin{array}{c}\text { Strongly } \\
\text { agree }\end{array}$ \\
\hline $\begin{array}{l}\text { 1. I learned about real world } \\
\text { relationships }\end{array}$ & 1 & 2 & 3 & 4 & 5 \\
\hline $\begin{array}{l}\text { 2. The guest speaker was } \\
\text { engaging and interesting }\end{array}$ & 1 & 2 & 3 & 4 & 5 \\
\hline $\begin{array}{l}\text { 3. The guest speaker promoted } \\
\text { his company/firm }\end{array}$ & 1 & 2 & 3 & 4 & 5 \\
\hline $\begin{array}{l}\text { 4. Other: Please list } \\
\text { ( }\end{array}$ & & & & \\
\hline
\end{tabular}

What were the guest speaker's personality traits?

\begin{tabular}{|l|c|c|c|c|c|}
\hline & $\begin{array}{c}\text { Strongly } \\
\text { disagree }\end{array}$ & Disagree & Undecided & Agree & $\begin{array}{c}\text { Strongly } \\
\text { agree }\end{array}$ \\
\hline 5. The guest speaker was pleasant & 1 & 2 & 3 & 4 & 5 \\
\hline $\begin{array}{l}\text { 6. The guest speaker was creative } \\
\text { and imaginative }\end{array}$ & 1 & 2 & 3 & 4 & 5 \\
\hline $\begin{array}{l}\text { 7. The guest speaker was self } \\
\text { disciplined and conscientious }\end{array}$ & 1 & 2 & 3 & 4 & 5 \\
\hline $\begin{array}{l}\text { 8. The guest speaker was } \\
\text { energetic, positive and } \\
\text { enthusiastic }\end{array}$ & 1 & 2 & 3 & 4 & 5 \\
\hline $\begin{array}{l}\text { 9. The guest speaker was } \\
\text { compassionate and friendly }\end{array}$ & 1 & 2 & 3 & 4 & 5 \\
\hline $\begin{array}{l}\text { 10. The guest speaker was calm } \\
\text { and relaxed }\end{array}$ & 1 & 2 & 3 & 4 & 5 \\
\hline $\begin{array}{l}\text { 11. The guest speaker was } \\
\text { humorous }\end{array}$ & 1 & 2 & 3 & 4 & 6 \\
\hline \begin{tabular}{l} 
12. Other: Please list \\
\hline
\end{tabular} & & & & & \\
\hline
\end{tabular}


Teaching presentation: Content and effectiveness

\begin{tabular}{|l|c|c|c|c|c|}
\hline & $\begin{array}{c}\text { Strongly } \\
\text { disagree }\end{array}$ & Disagree & Undecided & Agree & $\begin{array}{c}\text { Strongly } \\
\text { agree }\end{array}$ \\
\hline $\begin{array}{l}\text { 13. The guest speaker dressed } \\
\text { professionally }\end{array}$ & 1 & 2 & 3 & 4 & 5 \\
\hline $\begin{array}{l}\text { 14. The guest speaker was well } \\
\text { prepared }\end{array}$ & 1 & 2 & 3 & 4 & 5 \\
\hline $\begin{array}{l}\text { 15. The guest speaker was } \\
\text { organized }\end{array}$ & 1 & 2 & 3 & 4 & 5 \\
\hline $\begin{array}{l}\text { 16. The guest speaker obviously } \\
\text { knew her material }\end{array}$ & 1 & 2 & 3 & 4 & 5 \\
\hline $\begin{array}{l}\text { 17. The guest speaker was } \\
\text { intelligent }\end{array}$ & 1 & 2 & 3 & 4 & 5 \\
\hline $\begin{array}{l}\text { 18. The guest speaker was } \\
\text { interesting }\end{array}$ & 1 & 2 & 3 & 4 & 5 \\
\hline $\begin{array}{l}\text { 19. The guest speaker captured } \\
\text { and held my attention }\end{array}$ & 1 & 2 & 3 & 4 & 5 \\
\hline $\begin{array}{l}\text { 20. The presentation was thought } \\
\text { provoking }\end{array}$ & 1 & 2 & 3 & 4 & 5 \\
\hline $\begin{array}{l}\text { 21. The guest speaker } \\
\text { communicated at a level that I } \\
\text { understood }\end{array}$ & 1 & 2 & 3 & 4 & 5 \\
\hline $\begin{array}{l}\text { 22. The guest speaker was } \\
\text { relaxed }\end{array}$ & 1 & 2 & 3 & 4 & 5 \\
\hline $\begin{array}{l}\text { 23. The guest speaker effectively } \\
\text { communicated his/her subject of } \\
\text { expertise }\end{array}$ & 1 & 2 & 3 & 4 & 5 \\
\hline $\begin{array}{l}\text { 24. I would like to see this guest } \\
\text { speaker invited back to speak to } \\
\text { another class }\end{array}$ & 1 & 2 & 3 & 4 & 5 \\
\hline $\begin{array}{l}\text { 25. I would like to have more } \\
\text { sessions like this }\end{array}$ & 1 & 2 & 3 & 4 & 5 \\
\hline $\begin{array}{l}\text { 26. The guest speaker showed me } \\
\text { a new career option }\end{array}$ & 1 & 2 & 3 & 4 & 5 \\
\hline $\begin{array}{l}\text { 27. This experience was } \\
\text { beneficial for me }\end{array}$ & 1 & 2 & 3 & 4 & 5 \\
\hline $\begin{array}{l}\text { 28. Overall, the presentation was } \\
\text { a worthwhile, educational } \\
\text { experience }\end{array}$ & 1 & 2 & 3 & 4 & 5 \\
\hline
\end{tabular}


29. Did you ask the guest speaker a question?

Yes
$-\quad$ No

If yes, how many questions did you ask? guest speaker? How did you feel speaking with the

\begin{tabular}{|l|c|c|c|c|c|}
\hline & $\begin{array}{c}\text { Strongly } \\
\text { disagree }\end{array}$ & Disagree & Undecided & Agree & $\begin{array}{c}\text { Strongly } \\
\text { agree }\end{array}$ \\
\hline $\begin{array}{l}\text { 30. The speaker was easy to talk } \\
\text { to }\end{array}$ & 1 & 2 & 3 & 4 & 5 \\
\hline $\begin{array}{l}\text { 31. The speaker interacted well } \\
\text { with the students }\end{array}$ & 1 & 2 & 3 & 4 & 5 \\
\hline $\begin{array}{l}\text { 32. The speaker was a good role } \\
\text { model for me }\end{array}$ & 1 & 2 & 3 & 4 & 5 \\
\hline
\end{tabular}

\section{Technology}

\begin{tabular}{|l|c|c|c|c|c|}
\hline & $\begin{array}{c}\text { Strongly } \\
\text { disagree }\end{array}$ & Disagree & Undecided & Agree & $\begin{array}{c}\text { Strongly } \\
\text { agree }\end{array}$ \\
\hline $\begin{array}{l}\text { 33. The quality of the audio was } \\
\text { excellent }\end{array}$ & 1 & 2 & 3 & 4 & 5 \\
\hline $\begin{array}{l}\text { 34. The quality of the video was } \\
\text { excellent }\end{array}$ & 1 & 2 & 3 & 4 & 5 \\
\hline $\begin{array}{l}\text { 35. The projection screen was } \\
\text { large enough to see the guest } \\
\text { speaker comfortably }\end{array}$ & 1 & 2 & 3 & 4 & 5 \\
\hline $\begin{array}{l}\text { 36. During the session, the } \\
\text { technology functioned properly }\end{array}$ & & & & & \\
\hline
\end{tabular}




\section{Session Objectives}

\begin{tabular}{|l|c|c|c|c|c|}
\hline & $\begin{array}{c}\text { Strongly } \\
\text { disagree }\end{array}$ & Disagree & Undecided & Agree & $\begin{array}{c}\text { Strongly } \\
\text { agree }\end{array}$ \\
\hline 37. This session motivated me & 1 & 2 & 3 & 4 & 5 \\
\hline 38. This session entertained me & 1 & 2 & 3 & 4 & 5 \\
\hline 39. This session informed me & 1 & 2 & 3 & 4 & 5 \\
\hline $\begin{array}{l}\text { 40. I felt that I learned something } \\
\text { important during the session }\end{array}$ & 1 & 2 & 3 & 4 & 5 \\
\hline
\end{tabular}

41. What was the guest speaker's title and what are her/his job duties?

42. How does the guest speaker's job relate to what you are learning in the classroom?

43. What attitudes are important for career success?

44. Did you do research or read about the guest speaker and/or his company before the session?

$$
\begin{array}{cc}
\text { Yes } \\
-\quad \text { No }
\end{array}
$$

\section{Additional Questions}

45. What was the best part of using videoconferencing in this session?

46. What was the part you liked least about using videoconferencing in this session?

47. In one word, how would you describe this experience?

48. What is the most important thing you learned from this videoconferencing session? 
49. What do you see as the benefit(s) of using videoconferencing for a presentation by a guest speaker?

50. Was the information that you gained from the guest speaker useful?

$$
\begin{array}{ll}
\text { (a) Yes } \\
-\quad \text { (b) No }
\end{array}
$$

Why or why not?

51. What could have been done to improve this videoconferencing session?

52. What is your gender?
(a) Male
(b) Female
(c) Other

53. What is your ethnicity?
- (a) Caucasian
(b) African American
- (c) Hispanic
- (d) Asian
- (e) Pacific Islander
- (f) Native American
- (g) Other (please specify)

54. What is your age range?
- (a) Under 18
- (b) $18-25$
- (c) $26-35$
- (d) $36-50$
— (e) Over 50

55. What is the highest level of education completed?
(a) Less than high school
_ (b) High school or GED
(c) Associates of Arts Degree
(d) Bachelor's degree 
(e) Master's degree
(f) Doctorate
(g) Other___ (please specify)

56. What is our major?
- (a) Fashion Design
- (b) Fashion Merchandising
- (c) Other (please specify)

57. Prior to this session, how many times have you participated in a videoconferencing session?
- (a) Never
(b) One time
- (c) Two times
- (d) Three or more times

58. Have you ever used a web cam?
- (a) Yes
(b) No

59. Have you ever used Skype?
- (a) Yes
(b) No

60. Please share any other comments or questions that you have about this experience.

Thank you for completing this survey. 


\section{APPENDIX G}

INDUSTRY PROFESSIONAL PRE-SURVEY 


\section{Fashion industry Professional Pre-Survey}

1. How many years has the firm you work for been in business?

2. What product does your firm produce?

3. What is your employment position title?

4. How long have you held your current position in this company?

5. What is your highest completed educational level?

High School

— Fashion Certificate

- Associate's Degree

- Bachelor's Degree

— Master's Degree

- Doctorate

Please specify the major that was completed and/or other training.

6. Have you ever been a guest speaker?

Yes
$-\quad$ No

If yes, Where and in what capacity?

7. Have you ever worked with students before?

Yes
$-\quad$ No 
If yes, In what capacity?

8. What are your presentation expectations and goals?

\begin{tabular}{|c|c|c|c|c|c|}
\hline $\begin{array}{l}\text { I would help the } \\
\text { students learn about } \\
\text { the real world }\end{array}$ & $\begin{array}{l}\text { Strongly } \\
\text { Disagree }\end{array}$ & Disagree & Undecided & Agree & $\begin{array}{l}\text { Strongly } \\
\text { Agree }\end{array}$ \\
\hline $\begin{array}{l}\text { I would promote } \\
\text { my company }\end{array}$ & & & & & \\
\hline
\end{tabular}

I would find

potential future

employees

Please list other expectations and goals

9. Have you ever used Internet videoconferencing (including, for example, SKYPE, or another program) that uses a webcam?

Yes
$-\quad$ No

If yes, In what capacity? Business or pleasure? What program did you use? 
10. Please list any questions or concerns that you have about the upcoming videoconferencing session.

11. What motivates you to participate in an Internet videoconference with college fashion students?

12. What factors would hinder you or other fashion industry professionals from participating in an Internet videoconference with college fashion students? 
APPENDIX H

INDUSTRY PROFESSIONAL POST-SURVEY 
Apparel Industry Professional Post-Session Survey

1. What objectives do you eel were met during your presentation to the students?

\begin{tabular}{|l|c|c|c|c|c|}
\hline & $\begin{array}{c}\text { Strongly } \\
\text { disagree }\end{array}$ & Disagree & Neutral & Agree & $\begin{array}{c}\text { Strongly } \\
\text { agree }\end{array}$ \\
\hline $\begin{array}{l}\text { This session motivated the } \\
\text { students }\end{array}$ & 1 & 2 & 3 & 4 & 5 \\
\hline $\begin{array}{l}\text { This session entertained the } \\
\text { students }\end{array}$ & 1 & 2 & 3 & 4 & 5 \\
\hline $\begin{array}{l}\text { This session informed the } \\
\text { students }\end{array}$ & 1 & 2 & 3 & 4 & 5 \\
\hline $\begin{array}{l}\text { As a result of this session, } \\
\text { students will be able to describe } \\
\text { my job responsibilities }\end{array}$ & 1 & 2 & 3 & 4 & 5 \\
\hline $\begin{array}{l}\text { As a result of this session, } \\
\text { students will be able to relate } \\
\text { what goes on in the real world } \\
\text { with what goes on in the } \\
\text { classroom }\end{array}$ & 1 & 2 & 3 & 4 & 5 \\
\hline $\begin{array}{l}\text { The students learned something } \\
\text { important in the session }\end{array}$ & 1 & 2 & 3 & 4 & 5 \\
\hline Other (please specify) & & & & \\
\hline
\end{tabular}


2. How would you rate the effectiveness of the technology used during the videoconferencing session?

\begin{tabular}{|c|c|c|c|c|c|}
\hline & $\begin{array}{l}\text { Strongly } \\
\text { disagree }\end{array}$ & Disagree & Neutral & Agree & $\begin{array}{c}\text { Strongly } \\
\text { agree }\end{array}$ \\
\hline $\begin{array}{l}\text { The quality of the audio was } \\
\text { excellent }\end{array}$ & 1 & 2 & 3 & 4 & 5 \\
\hline $\begin{array}{l}\text { The quality of the video was } \\
\text { excellent }\end{array}$ & 1 & 2 & 3 & 4 & 5 \\
\hline $\begin{array}{l}\text { During the session, the } \\
\text { technology functioned properly }\end{array}$ & 1 & 2 & 3 & 4 & 5 \\
\hline $\begin{array}{l}\text { I could see each student clearly } \\
\text { as he asked his/her question }\end{array}$ & 1 & 2 & 3 & 4 & 5 \\
\hline \multicolumn{6}{|c|}{ Please write any other comment(s) that you have about the technology } \\
\hline
\end{tabular}




\section{Teaching Presentation: Content and Effectiveness}

Please rate to what degree the following factors were true in your assessment of yourself.

\begin{tabular}{|c|c|c|c|c|c|}
\hline & $\begin{array}{l}\text { Strongly } \\
\text { disagree }\end{array}$ & Disagree & Neutral & Agree & $\begin{array}{l}\text { Strongly } \\
\text { agree }\end{array}$ \\
\hline I was well prepared & 1 & 2 & 3 & 4 & 5 \\
\hline I was organized & 1 & 2 & 3 & 4 & 5 \\
\hline I was interesting & 1 & 2 & 3 & 4 & 5 \\
\hline $\begin{array}{l}\text { I captured and held the students' } \\
\text { attention }\end{array}$ & 1 & 2 & 3 & 4 & 5 \\
\hline $\begin{array}{l}\text { My presentation was thought } \\
\text { provoking }\end{array}$ & 1 & 2 & 3 & 4 & 5 \\
\hline I was relaxed & 1 & 2 & 3 & 4 & 5 \\
\hline \multicolumn{6}{|l|}{$\begin{array}{l}\text { I used a visual aid in my } \\
\text { presentation }\end{array}$} \\
\hline \multicolumn{6}{|l|}{$\begin{array}{l}\text { I enjoyed interacting with the } \\
\text { students }\end{array}$} \\
\hline \multicolumn{6}{|l|}{$\begin{array}{l}\text { My preparation for this session } \\
\text { was easy }\end{array}$} \\
\hline \multicolumn{6}{|l|}{$\begin{array}{l}\text { Overall, the presentation was a } \\
\text { worthwhile, educational } \\
\text { experience }\end{array}$} \\
\hline 4. Other (please specify) & & & & & \\
\hline
\end{tabular}




\section{Self Perception:}

Please rate how you felt you were perceived by the students.

\begin{tabular}{|l|c|c|c|c|c|}
\hline & $\begin{array}{c}\text { Strongly } \\
\text { disagree }\end{array}$ & Disagree & Neutral & Agree & $\begin{array}{c}\text { Strongly } \\
\text { agree }\end{array}$ \\
\hline I thought I appeared positive & 1 & 2 & 3 & 4 & 5 \\
\hline I thought I appeared self-assured & 1 & 2 & 3 & 4 & 5 \\
\hline $\begin{array}{l}\text { I thought I appeared interested in } \\
\text { the students }\end{array}$ & 1 & 2 & 3 & 4 & 5 \\
\hline I thought I appeared humorous & 1 & 2 & 3 & 4 & 5 \\
\hline I thought I appeared relaxed & 1 & 2 & 3 & 4 & 5 \\
\hline $\begin{array}{l}\text { I thought I appeared } \\
\text { professionally dressed }\end{array}$ & 1 & 2 & 3 & 4 & 5 \\
\hline
\end{tabular}

List any other impression that you think you conveyed to the students.

5. In one word, how would you describe this videoconferencing session?

6. What was the best part of using videoconferencing in this session?

7. What was the part you liked least about using videoconferencing in this session?

What improvements are needed? 
8. What factors would motivate you to visit the classroom via Internet videoconferencing again?

9. Would you be willing to do this again? Please explain why or why not.

10. What factors would hinder you in visiting the classroom via Internet videoconferencing?

11. What benefits are there for apparel industry professionals who participate in this type of videoconferencing session with fashion students?

12. How do you think your presentation benefited the students?

13. Do you have other colleagues that would be willing to participate in guest sneaking via Internet videoconferencing? What would motivate them to participate? 
14. What is your perception or comments about the students that you worked with during this session?

15. Please share any comments, suggestions or questions you have about the videoconferencing session. 


\section{APPENDIX I}

INSTRUCTOR CONSENT FORM 


\title{
San Diego State University
}

\author{
Consent to Act as a Research Subject (For Instructors)
}

\begin{abstract}
Study Title: Using Internet Videoconferencing to Connect Fashion Students to Apparel Industry Professionals.
\end{abstract}

You are being asked to participate in a research study. Before you give your consent to volunteer, it is important that you read the following information and ask as many questions as necessary to be sure you understand what you will be asked to do.

Investigators: Vera Bruce Ashley, a student doctoral candidate at the University of San Diego/San Diego State University (joint doctoral program) is conducting a study on using Internet videoconferencing to connect fashion students to apparel industry professionals.

Vera Bruce Ashley, who holds a master's degree in family and consumer sciences from Cal State Long Beach is conducting this study under the research supervision of Douglas Fisher, $\mathrm{PhD}$., who is Professor of Language and Literacy Education in the Department of Teacher Education at San Diego State University.

\section{Purpose of the Study:}

The purpose of the study is to explore the benefits, effectiveness, perceptions and practicality of using Internet videoconferencing software and a web cam to connect higher education (college and university) adult (18 and over) fashion students with apparel industry professionals. This is a multiple case qualitative study using two sets of partner participants which include the school/student group as the school partner and the apparel industry professional as the industry partner. This study will examine these variables from the perspective of instructors, students and apparel industry professionals. There are four study research questions:

\section{RESEARCH QUESTIONS}

1. What are the expectations of the student, teacher and apparel industry professional before engaging in the videoconferencing session?

2. How do students perceive the experience of interacting with apparel industry professionals who visit the classroom via internet videoconferencing?

a. How do the students rate the apparel industry professional's personality traits?

b. What are the students' perception of the apparel industry professional's effectiveness and content knowledge?

c. How did students rate the technology? 
d. What was the students' overall perception of the experience?

1. What expectations were met?

2. Of those students who interacted with the speaker, how did they rate that experience?

3. How do instructors perceive the experience of interacting with apparel industry professionals who visit the classroom via internet videoconferencing?

(a) Can instructor's student learning objectives be met when using apparel industry professionals who visit the classroom via internet videoconferencing?

(b) What presentation expectations were met during the internet videoconferencing session?

(c) How did instructors assess the apparel industry professional's personality traits?

(d) How did instructors assess the apparel industry professional's content and effectiveness?

(e) How did instructors rate the technology?

4. How do apparel industry professionals who visit and interact with fashion students via internet videoconferencing perceive the experience?

(a) How does the apparel industry professional feel that they are perceived by the students?

(b) What is the apparel industry professional's self assessment during the session?

(c) How did apparel industry professionals rate the technology?

(d) What factors motivate the apparel industry professional to participate in an internet videoconferencing session?

(e) What factors hinder the apparel industry professional in engaging in an internet videoconferencing interaction with students?

(f) What is the perceived value to the apparel industry professional in interacting with fashion students via internet videoconferencing?

One instructor with his classroom students and one apparel industry professional is sought for each one of the case studies. The eligibility criteria for the fashion design instructor/ 
classroom partner include interest in the study and the instructor must be teaching a fashion class and have access to a computer, the Internet and a projection system (i.e. smart classroom) with the ability to download free videoconferencing software, web cam software, and a web cam (which will be provided, if necessary) onto the class computer. The instructor also must have access to help desk personnel during the videoconferencing session. You were chosen because you meet the eligibility criteria for this study. The instructors' adult students (18 and over) are automatically included as participants with the instructor.

The eligibility criteria for the apparel industry professional include interest in the study and the ability to download free videoconferencing software, web cam software, and a web cam (which will be provided, if necessary) onto the computer they will be using during the videoconferencing session.

\section{Description of the Study:}

The study involves an Internet videoconferencing session (approximately 30 minutes)

\section{Completion of Pre-Session Survey (15 minutes) via Internet}

2.. When a match is found, Internet videoconferencing download instructions, a web cam and software (if necessary) will be sent to you (15 minutes).

3. An Internet videoconferencing connection with the researcher will take place within two weeks of the planned videoconferencing session to make sure connectivity is working. A date and time will be arranged (Approx 5 minutes).

4. Instructor will inform students about the internet guest speaker and ask students to generate eight to ten questions about information that they would like to receive from the guest speaker. Students should also be instructed to conduct research on the firm or industry professional who is to be represented in the session, if desired. Instructor will email student generated questions to the researcher by arranged date.

5. The researcher will, from the list of questions, categorize them and choose which ones will constitute the ten minute opening starter talk by the fashion industry professional and which ones will be asked by the students as they interact individually with the fashion industry professional. The researcher will send the questions to the fashion industry professional within ten days of the videoconferencing session.

6. An email reminder will be sent to both parties, from the researcher, within a week of the videoconferencing session. A time will be arranged for the researcher/instructor to test the videoconferencing connection with the fashion industry professional within 3 days of the session (10 minutes).

7. On the day of the session, the fashion industry professional will talk with the students (via the internet) based on the questions sent to him/her by the researcher. After the 
introductory talk by the fashion industry professional, students will come up to the camera and interact with the fashion industry professional by asking individual questions (Session should be less than 30 minutes). The fashion industry professional will complete a post session survey immediately after the internet videoconferencing session(15 minutes).Prior to the session, students would have filled out a pre session survey and following the session, students complete an after session surveys. The instructor also completes an after session survey.

8. Approximately one month after the videoconferencing session, preliminary study findings are emailed to the instructor and fashion industry professional for written feedback (15 minutes). This is done as a member check and to control for bias and also acts a method of triangulation.

Approximate total time commitment is approximately $21 / 4$ hours.

What is Experimental in this Study: "None of the procedures or questionnaires used in this study are experimental in nature. The only experimental aspect of this study is the gathering of information for the purpose of analysis."

\section{Risks or Discomforts:}

The risks and discomfort associated with participation in this study are no greater than those ordinarily encountered in daily life when speaking to a group of people. If the fashion industry professional begins to feel uncomfortable while participation, he/she may discontinue participation, either temporarily or permanently.

\section{Benefits of the Study:}

The fashion industry professional could benefit "socially" by being connected to and aware of what is happening in the fashion classroom. The instructor and his students could benefit by having an "inside look" into the fashion business. Students could learn what it is like to work in the fashion industry and learn the duties of various employment/career positions. This study could also contribute to the body of research in this field by establishing a method by which schools can be connected to fashion industry professional. I cannot guarantee, however, that you will receive any benefits from participating in this study.

\section{Confidentiality:}

Confidentiality will be maintained to the extent allowed by law. Survey interview responses and data collected through observation will not be linked in any way to your name or identity. All data collected from you will be numerically coded and thus not be identified by name. Once coded, the data obtained from the quantitative and qualitative surreys will be analyzed. All data will be stored and kept secure by the researcher in a private, locked residence. Data will be kept for five years after dissertation publication and then shredded. No one other than the researcher will have access to data files. 
Incentives to Participate:

The fashion industry professionals and the instructors will not be paid to participate in this study. The students in each class however, who submit a pre session and post session survey will be given a ticket to be deposited into a box for two drawings. The incentive/price of five dollars will be provided by the researcher. The instructor will pull twice for the drawing.

Costs and/or Compensation for Participation: There are no costs associated for the instructors, students or fashion industry professionals with participation in this study

Voluntary Nature of Participation: Participation in this study is voluntary. Your choice of whether or not to participate will not influence your future relations with San Diego State University or the University of San Diego. If you decide to participate, you are free to withdraw your consent and to stop your participation at any time without penalty or loss of benefits to which you are allowed.

Questions about the Study: If you have any questions about the research now, please ask. If you have questions later about the research, you may contact Vera Bruce Ashley at $\operatorname{xxXXXXXXXXXx}$

If you have any questions about your rights as a participant in this study, you may contact the Institutional Review Board at San Diego State University (telephone: 619-594-6622; email: irb@mail.sdsu.edu).

Consent to Participate: The San Diego State University Institutional Review Board has approved this consent form. Please fax this signed form to $\operatorname{xxxxxxxxxxxxxxxxxxAttn:~Vera~}$ Bruce Ashley.

Your signature below indicates that you have read the information in this document and have had a chance to ask any questions you have about the study. Your signature also indicates that you agree to be in the study and have been told that you can change your mind and withdraw your consent to participate at any time. You have been given a copy of this consent form. You have been told that by signing this consent form you are not giving up any of your legal rights.

Name of Participant (please print)

Signature of Participant

Date

Signature of Investigator

Date 
APPENDIX K

\section{STUDENT CONSENT FORM}




\section{Student Consent Form}

\section{Dear Student:}

You are invited to participate in a research study for a doctoral dissertation conducted by Vera Bruce, a doctoral candidate in the Joint Educational Doctorate Program at the University at San Diego's and San Diego State University. The title of the dissertation is Using Internet Videoconferencing to Connect Fashion Students to Apparel Industry Professionals.

You were identified as a possible participant in the study because you are a student in a fashion class in a higher education facility. The purpose of the study is to explore the benefits, effectiveness, perceptions and practicality of using internet videoconferencing software and a web cam to connect higher education (college and university) adult (18 and over) fashion students with apparel industry professionals. This study will examine these variables from the perspective of instructors, students and apparel firm representatives. There are six main research questions:

1. What are the expectations of the student, instructor and fashion industry professional before engaging in the Internet videoconferencing session?

2. How do students perceive the experience of interacting with the fashion industry professional who visits the classroom via Internet videoconferencing?

3. Is there a difference in the perception of the videoconference session between schools or based on the guest speaker?

4. Can instructors' student learning objectives be met when using fashion industry guest speakers who visit the classroom via Internet videoconferencing?

5. How do fashion industry professionals who visit and interact with fashion students via Internet?

6. What are the hindrances to the process of setting up Internet videoconferencing in the classroom with higher education classes?

Study participants include three instructors who teach fashion classes and his/her students, and three apparel industry professionals. The researcher is interested in your perspective of the experience of the videoconferencing session with an apparel industry professional. The survey is anonymous and voluntary. You will not be penalized if you decide not to participate in the study.

Your participation is voluntary. All data collected from you or your classroom will be numerically coded and cannot be identified by name. Once coded, the data obtained from the quantitative and qualitative surreys will be analyzed. All data will be kept secure by the researcher in a private location. 
The survey is in two parts. The first part is a pre-survey which contains four questions that relate to your expectations of the videoconferencing session. The second part is a post session survey that will be distributed after the videoconferencing session. This survey asks demographic questions to which you are to the chose the most accurate response, statements which concern your perceptions/evaluations about the presentation where you are to circle your responses, and open ended questions to which a written response is indicated.

An incentive for completing the survey will be offered. You will be given a two part numbered ticket that will be attached to the pre session survey. You will write that number on the pre session survey when you receive it. You will keep the two part ticket and write that same number on the post session survey when it is distributed to you after the videoconferencing session. After you finish the survey, you will give the completed post survey to the researcher and tear off one part of the ticket to keep and the other part will be dropped in a container for a drawing. There will be two tickets drawn by your instructor. Each winner will win a five dollar bill.

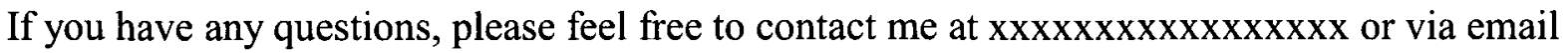
xxxxxxxxxxxxxxxxx You may also contact the San Diego State University. You may also contact the San Diego State University Institutional Review Board at (619) 594-6622. I thank you in advance for taking part in this study.

Sincerely, Vera Bruce, Researcher xxxxxxxxxxxxxxxxxxx 